ISIS ANDRÉA VENTURINI POLA POIATE

\title{
ANÁLISE BIOMECÂNICA DE DENTES \\ RESTAURADOS COM RETENTOR INTRA-RADICULAR \\ FUNDIDO, COM E SEM FÉRULA
}

São Paulo 


\title{
Isis Andréa Venturini Pola Poiate
}

\author{
Análise biomecânica de dentes restaurados com \\ retentor intra-radicular fundido, com e sem férula
}

Tese apresentada à Faculdade de Odontologia da Universidade de São Paulo, para obter o título de Doutor pelo Programa de PósGraduação em Odontologia.

Área de Concentração: Materiais Dentários

Orientador: Prof. Dr. Rafael Yagüe Ballester

São Paulo 
Catalogação-na-Publicação

Serviço de Documentação Odontológica

Faculdade de Odontologia da Universidade de São Paulo

Poiate, Isis Andréa Venturini Pola Poiate

Análise biomecânica de dentes restaurados com retentor intra-radicular fundido, com e sem férula./ Isis Andréa Venturini Pola Poiate; orientador: Rafael Yagüe Ballester. - São Paulo, 2007.

80 p.: fig.,; $30 \mathrm{~cm}$.

Tese (Doutorado - Programa de Pós-Graduação em Odontologia. Área de Concentração: Materiais dentários) -- Faculdade de Odontologia da Universidade de São Paulo.

1. Restauração dentária - Retentor radicular fundido - Análise biomecânica 2. Materiais dentários

CDD 617.685

BLACK D15

AUTORIZO A REPRODUÇÃO E DIVULGAÇÃO TOTAL OU PARCIAL DESTE TRABALHO, POR QUALQUER MEIO CONVENCIONAL OU ELETRÔNICO, PARA FINS DE ESTUDO E PESQUISA, DESDE QUE CITADA A FONTE E COMUNICADO AO AUTOR A REFERÊNCIA DA CITAÇÃO.

São Paulo, 1

Assinatura:

E-mail:pola@usp.br 


\section{FOLHA DE APROVAÇÃO}

Poiate IAVP. Análise biomecânica de dentes restaurados com retentor intra-radicular fundido, com e sem férula [Tese de Doutorado]. São Paulo: Faculdade de Odontologia da USP; 2007.

São Paulo, $/ 2007$

\section{Banca Examinadora}

1) $\operatorname{Prof}(a) \cdot \operatorname{Dr}(a)$.

Titulação:

Julgamento:

Assinatura:

2) $\operatorname{Prof}(a) \cdot \operatorname{Dr}(a)$.

Titulação:

Julgamento:

Assinatura:

3) $\operatorname{Prof}(a) \cdot \operatorname{Dr}(a)$.

Titulação:

Julgamento:

Assinatura:

4) $\operatorname{Prof}(\mathrm{a}) \cdot \operatorname{Dr}(\mathrm{a})$.

Titulação:

Julgamento:

Assinatura:

5) $\operatorname{Prof}(a) . \operatorname{Dr}(a)$.

Titulação:

Julgamento:

Assinatura: 


\section{DEDICATÓRIA}

Aos meus pais, Izes Helena e Osmar,

Vocês representam toda a energia que me impulsiona e me fortalece para que eu possa enfrentar os desafios, como este que está chegando ao final. Do fundo do meu coração, agradeço pelo carinho e, principalmente, pela paciência e companheirismo que vocês sempre demonstraram durante todos os instantes de nossas vidas. Dedico este trabalho a vocês, pelo amor e dedicação muitas vezes infinitos.

\section{Ao meu marido, Edgard,}

É impossivel agradecer toda a confiança e admiração que você sempre demonstrou pelos meus sonhos e meu trabalho. Sem você nada disto teria sentido. A você dedico este estudo, por todas as vezes que você está ao meu lado, por toda a alegria que você traz para a minha vida, por todo sonho que você torna realidade, por todo amor que encontro em você.

Ao meu irmão, Ives Renê,

Mesmo estando distante, você partilhou de todas as dificuldades $e$ alegrias. Agradeço pelo incentivo e desejo de seguirmos juntos nossos sonhos e por todo o carinho e amizade que sempre nos uniu.

\section{A minha cunhada, Fernanda,}

Amiga e companheira, que nos contagia com sua simpatia e alegria. Sua determinação e energia são contagiantes. Continue sempre assim! 


\section{AGRADECIMENTOS}

Ao meu orientador Prof. Dr. Rafael Yagüe Ballester, sua orientação me tornou uma profissional mais crítica e cautelosa. Agradeço pela oportunidade de realizar o meu doutorado, cristalizando esse passo importante de minha carreira. Muito Obrigada!

A Profa. Dra. Rosa Helena Miranda Grande, obrigada pela maneira atenciosa com que sempre respondeu as minhas dúvidas, e por estar sempre pronta a ajudar e ensinar.

Ao Prof. Dr. Adalberto Bastos de Vasconcellos, por ter colaborado de forma tão incisiva em minha formação. Agradeço pelo incentivo e apoio constantes em minha carreira acadêmica.

Às queridas super amigas: Adriana, meiga, delicada, mas forte e guerreira. Com seu Jeitinho especial conquista a todos e nos mostra a maravilhosa pessoa que é; Soraia, que se mostrou uma amiga a qualquer momento. Admiro muito seu caráter, competência e honestidade.

Às amigas, Andréa, Maria Teresa, Flávia Pires, vocês são divertidas, companheiras e inesqueciveis. Tenho muito orgulho de cada uma de vocês. Obrigada pelo incentivo e por me ouvirem a qualquer momento.

Às secretárias do departamento de Materiais Dentátios: Rosinha, sempre pronta pra dar uma mão no que precisamos; Mirtes, pelo prazer de conhecer, conviver e ter por perto uma pessoa tão especial como você.

\section{A todos os professores e técnicos do Departamento de Materiais}

Dentários da FOUSP, por se preocuparem com nossa formação.

Aos colegas de pós-graduação, pela amizade e companheirismo.

Aos funcionários da Biblioteca, pelo carinho e amizade com que sempre me atenderam. 
Poiate IAVP. Análise biomecânica de dentes restaurados com retentor intraradicular fundido, com e sem férula [Tese de Doutorado]. São Paulo: Faculdade de Odontologia da USP; 2007.

\section{RESUMO}

O objetivo foi avaliar a influência de variações no formato da férula dada por núcleo estojado sobre as tensões desenvolvidas na raiz em um modelo tridimensional de um segundo pré-molar superior submetido a quatro condições de carregamentos: cunha, alavanca vestibular, alavanca proximal e torção. Seis modelos foram confeccionados a partir das dimensões médias obtidas na literatura. Um deles representou o dente hígido, e outros cinco dentes restaurados com coroa e retentor intra-radicular fundido: um simulou núcleo simples, sem férula (E2A0), e em quatro modelos variou-se o tamanho do espelho (E) em 1/3 da espessura da parede radicular (E1) ou 2/3 (E2) e a altura (A) da férula foi equivalente a E1 (A1) ou a E2 (A2); ou seja: os modelos E1A1 e E2A2 tiveram $45^{\circ}$ de inclinação do bisel da férula. Todas as estruturas foram consideradas homogêneas, isotrópicas e lineares elásticas. Os resultados permitem afirmar que a férula não parece necessária para melhorar a distribuição de tensões e que, exceto para o caso de carregamento longitudinal (que demonstrou ser o menos danoso), o cimento ficou submetido a tensões que justificam sua fratura e a dentina apresentou tensões de tração compatíveis com fraturas longitudinais (com início na crista óssea), especialmente para a alavanca vestibular.

Palavras-Chave: Análise de elementos finitos; Férula; Retentor intra-radicular. 
Poiate IAVP. Biomechanics analysis of restored teeth with cast intra-radicular retainer, with and without ferrule [Tese de Doutorado]. São Paulo: Faculdade de Odontologia da USP; 2007.

\section{ABSTRACT}

The aim was to evaluate the influence of variations in the radicular ferrule format given by the casing core on stress developed in the root in a three-dimensional model of one upper second premolar submitted to four load conditions: wedge, vestibular lever, proximal lever and torsion. Six models were built according the average dimensions obtained from the literature. One of them represented the sound tooth, and other five restored teeth with cast radicular retainer and crown: one simulated simple core, without ferrule (E2A0), and in four models the mirror (E) size was varied in $1 / 3$ of the radicular wall thickness (E1) or $2 / 3(E 2)$ and the ferrule height (A) was equivalent to E1 (A1) or E2 (A2); or be: E1A1 and E2A2 had $45^{\circ}$ inclination of the ferrule bisel. All the structures were considered homogeneous, isotropic and linear elastic behavior. The results allow to affirm that the ferrule doesn't seem necessary to improve the stress distribution and that, except for the longitudinal load case (that demonstrated to be the least harmful), the cement was submitted to stress that justify his fracture and the dentine presented compatible tensile stress with longitudinal fractures (with beginning in the bone crest), especially for the vestibular lever.

Keywords: Finite element analysis; Ferrule; Intra-radicular retainer. 
1 INTRODUÇÃO

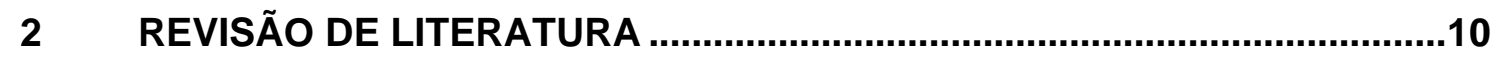

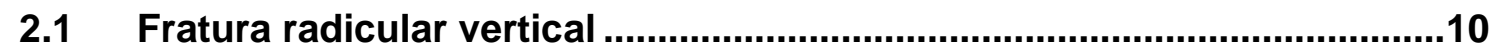

2.2 Fatores mecânicos relacionados com a fratura radicular vertical ..........13

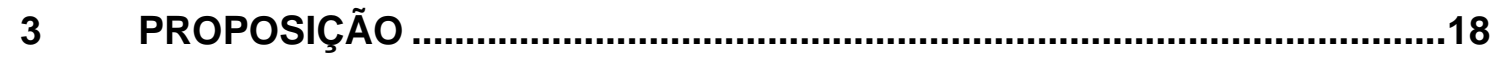

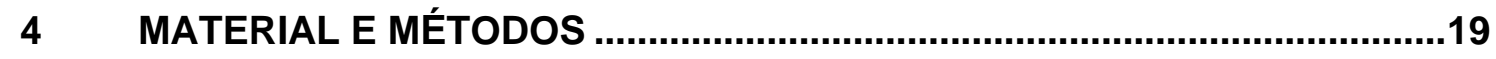

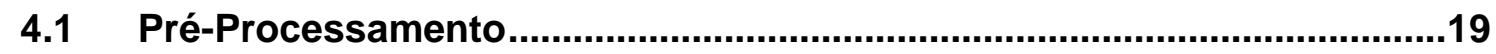

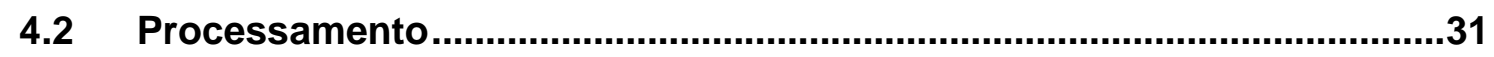

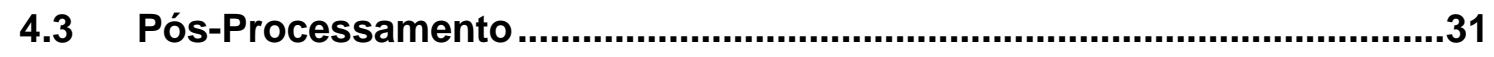

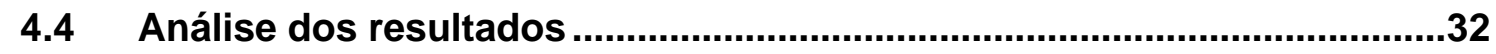

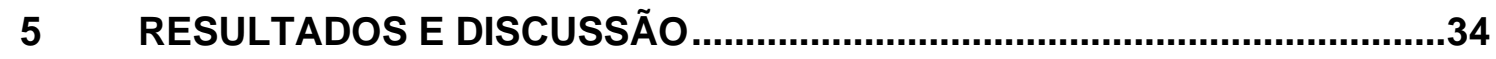

5.1 Efeito Cunha - Carregamento com resultante paralela ao longo eixo....34

5.2 Efeito alavanca vestibular- Carregamento $45^{\circ}$ na cúspide vestibular....45

5.3 Efeito alavanca proximal - Carregamento $0^{\circ}$ na crista marginal mesial.52

5.4 Efeito Torção - Carregamento $45^{\circ}$ na crista marginal mesial...................57

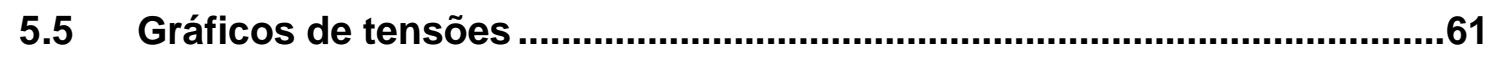

6 CONCLUSÕES

REFERÊNCIAS 


\section{INTRODUÇÃO}

Para a reconstrução protética de dentes com grande destruição coronária torna-se muitas vezes indispensável obter retenção mediante o uso de pinos intraradiculares. A perda de retenção e as fraturas dentárias são as duas falhas mais comumente descritas neste tipo de restauração (FERRARI; MANNOCCI, 2000).

A fratura dentária tende a ocorrer longitudinalmente com término abaixo da crista alveolar óssea, o que constitui uma falha não restaurável e conduz à perda do dente. Este tipo de falha é atribuído principalmente ao uso de pinos com comprimento e/ou diâmetro incorreto e deficiências na preservação da estrutura dentária (FERRARI; MANNOCCI, 2000).

Alguns autores afirmam que um dente despolpado torna-se mais frágil com o tempo, devido à dessecação ou perda prematura de fluidos fornecidos pela polpa dental (ASSIF; GORFIL, 1994; GUTMANN, 1992).

É inquestionável que a perda de estrutura dentária torne o dente tratado endodonticamente mais susceptível a fraturas. Esta perda ocorre não só como decorrência do processo carioso, mas também como resultado das operações da terapia endodôntica e protética. A cirurgia de acesso à câmara pulpar, a instrumentação do canal radicular e o preparo para pino eliminam porções importantes para resistência global do dente, o que fragiliza o conjunto.

O pino intra-radicular é usado para providenciar retenção a um núcleo, mas também teria a função de distribuir o carregamento funcional para uma maior área da estrutura remanescente coronária e raiz (BARABAN, 1976). Entretanto, tem sido mostrado que os pinos não reforçam dentes tratados endodonticamente. Muitos 
autores (ASSIF; GORFIL, 1994; MARTINEZ-INSUA et al., 1999) têm demonstrado que este método restaurador não devolve a resistência à fratura que um dente vital possui, o que é atribuído ao efeito de cunha que este tipo de restauração causa e às diferenças de rigidez entre o pino e o dente.

Uma tentativa para aumentar a resistência da raiz frente aos carregamentos fisiológicos é a confecção de férula, propiciada pelo núcleo ou pela coroa, que tende a produzir o abraçamento da estrutura dental em torno do pino. A férula é um colar metálico de $360^{\circ}$ que circunda as paredes axiais da dentina remanescente. Estende-se ao ombro do preparo, numa altura mínima de 1,5 a $2 \mathrm{~mm}$ da estrutura intacta de dente (MORGANO, 1996; MORGANO; BRACKETT, 1999).

Segundo Loney, Kotowiez e McDowel (1990), a férula fornecida pelo núcleo contribui para a distribuição mais equilibrada das tensões na raiz e poderia comprimir a estrutura remanescente. Assif e Gorfil (1994), Barkhordar, Radke e Abbasi (1989) e Isidor, Brondum e Ravnholt (1999) encontraram melhores propriedades de retenção do pino e maior resistência da raiz quando foi usada alguma férula.

A compreensão dos princípios biomecânicos aplicáveis às restaurações é importante para projetar restaurações que providenciem maior resistência e retenção. Faltam informações na literatura corrente sobre quais seriam os formatos ideais da férula formada pelo núcleo estojado. O objetivo deste trabalho foi avaliar a influência de variações no formato da férula sobre as tensões desenvolvidas na raiz, quando um segundo pré-molar superior é submetido a quatro diferentes condições de carregamentos. 


\section{REVISÃO DE LITERATURA}

Para melhor entendimento do assunto proposto, foi feita uma abordagem sobre a incidência das Fraturas Radiculares Verticais (FRV) associadas ao uso de

pinos intra-radiculares, com ênfase nos procedimentos capazes de prevenir sua ocorrência. A seguir, são tratados tópicos referentes aos principais fatores mecânicos relacionados com a FRV de dentes restaurados com retentor intraradicular fundido. Eles são denominados de efeito cunha, efeito alavanca e efeito torção. Os estudos sobre efeito férula também são descritos neste capítulo.

\subsection{Fratura radicular vertical}

\subsubsection{Etiologia}

A FRV em dentes tratados endodonticamente pode ser definida como aquela cuja linha é orientada no sentido longitudinal, passa pela parede do canal e se estende até a superfície radicular externa, em direção aos tecidos periodontais. Ocorre em qualquer terço da raíz e tende a separá-la vestíbulo-lingualmente. Estas fraturas também são conhecidas como fraturas iatrogênicas da raiz (HOWE; MCKENDRY, 1990; LERTCHIRAKARN; PALAMARA; MESSER, 1999).

Dentre os fatores relacionados com a etiologia da FRV, destacam-se a provável perda da umidade dentinária de dentes desvitalizados, bem como os 
procedimentos endodônticos e protéticos realizados de forma inadequada (HOWE; MCKENDRY, 1990; IMURA; ZUOLO, 1998; LLOYD; PALIK, 1993; ONNINK; DAVIS; WAYMAN, 1994; PAPA; CAIN; MESSER, 1994; TAMSE et al., 1999a).

A princípio, supôs-se que a perda do conteúdo de água dos tecidos calcificados de dentes submetidos à terapia endodôntica poderia torná-los susceptíveis às fraturas, entretanto estudos demonstraram que a redução da umidade dentinária é mínima quando comparada à dos dentes vitais, e não interfere significativamente na dureza dentinária (HELFER; MELNICK; SCHILDER, 1972; LEWINSTEIN; GRAJOWER, 1981; PAPA; CAIN; MESSER, 1994; REEH; MESSER; DOUGLAS, 1989; SEDGLEY; MESSER, 1992). A propósito, os autores esclarecem que as perdas cumulativas de estrutura dental por cáries, trauma e procedimentos restauradores, são os fatores responsáveis pelo aumento da susceptibilidade destes dentes às fraturas.

A utilização de pinos inadequados à morfologia radicular, associada às tensões oclusais excessivas, contribuem para a origem de fraturas verticais. Em função disso, alguns critérios devem ser respeitados durante a fabricação de um pino, são eles: tipo, configuração da superfície, comprimento e diâmetro (LLOYD; PALIK, 1993; SORENSEN; MARTINOFF, 1984).

Diversos estudos foram realizados com o objetivo de determinar que tipo de retentor intra-radicular ofereceria menor risco de causar FRV e todos foram unânimes ao reconhecerem que o pino paralelo serrilhado é o mais adequado, pois promove boa retenção sem originar concentração de tensões e sem produzir efeito de cunha, características estas que não são observadas nos retentores metálicos fundidos (CAPUTO; STANDLEE, 1976; GOERIG; MENINGHOFF, 1983; SORENSEN; MARTINOFF, 1984; TESTORI; BADINO; CASTAGNOLA, 1993). 
Os retentores metálicos fundidos, apesar de serem morfologicamente semelhantes ao canal radicular, apresentam alta taxa de fracasso clínico que pode ser explicada por serem menos retentivos, promoverem ação de cunha e possuírem alto módulo de elasticidade (GOERIG; MUENINGHOFF, 1983; SORENSEN; MARTINOFF, 1984), que resulta em aumento de tensões.

Outro aspecto bastante analisado é o comprimento de pinos intra-radiculares, constituindo-se em uma das principais causas das falhas nas restaurações de dentes tratados endodonticamente. A utilização de pinos curtos, além de promover pouca retenção, induz a fratura da raiz (GUTMANN, 1977).

A recomendação para o comprimento do pino varia conforme o autor: igual ou maior ao comprimento da coroa, ou ter dois terços do comprimento da raiz, ou possuir metade do comprimento da raiz suportada por osso alveolar (BARABAN, 1988; SORENSEN; MARTINOFF, 1984).

O pino deve ter diâmetro suficiente para resistir às forças funcionais. Um diâmetro maior não proporciona melhora na retenção do pino-raiz, mas diminui significativamente a resistência da raiz à fratura. Por esta razão, tem-se sugerido que o diâmetro do pino não ultrapasse $1 / 3$ do diâmetro total da raiz (CAPUTO; STANDLEE, 1976).

\subsubsection{Incidência}

A literatura relata que a FRV pode ocorrer em qualquer grupo dental, em dentes vitais e não vitais. Entretanto, dentes que apresentam raízes com 
achatamento mésio-distal e foram submetidos à terapia endodôntica são os mais susceptíveis (CHAN et al., 1998; IMURA; ZUOLO,1998; TAMSE et al., 1999a).

Testori, Badino e Castagnola (1993) avaliaram a incidência de fraturas radiculares verticais em dentes tratados endodonticamente e concluíram que o maior índice de fraturas radiculares verticais, em ordem decrescente, ocorreu em pré-molares, molares, caninos e incisivos.

Tamse et al. (1999a) avaliaram 92 dentes tratados endodonticamente com diagnóstico de FRV obtido através de exames clínicos e radiográficos e constataram maior índice de fraturas para os pré-molares superiores e inferiores (52\%), e que os segundos pré-molares superiores representaram 27\% destas, seguidos das raízes mesiais dos molares inferiores (24\%), raízes mésio-vestibulares e palatinas dos molares superiores (10\%) e incisivos centrais e laterais, superiores e inferiores $(14 \%)$.

Diante destas considerações, alguns autores (TAMSE; ZILBURG; HALPERN, 1998; TAMSE et al., 1999b) asseguram que um dos principais fatores que predispõe os pré-molares à fratura radicular vertical é a sua anatomia (o diâmetro mésio-distal é menor que a distância vestíbulo-lingual).

\subsection{Fatores mecânicos relacionados com a fratura radicular vertical}

Quando são usados pinos, alguns autores atribuem a fratura radicular vertical ao efeito cunha (ASMUSSEN; PEUTZFELDT; SAHAFI, 2005; ASSIF; GORFIL, 1994; COONEY; CAPUTO; TRABERT, 1986; MARTINEZ-INSUA et al., 1999). Este efeito aparece quando o carregamento favorece a intrusão de um pino com formato tronco 
cônico no interior da raiz, ou mesmo durante um tratamento endodôntico, quando é realizada a condensação lateral dos cones de gutta-percha (DULAIMI; WALI ALHASHIMI, 2005; LERTCHIRAKARN; PALAMARA; MESSER, 2003). Ao ser empurrada, a cunha tende a aumentar o perímetro da seção transversal do remanescente, e aparecem tensões de tração orientadas paralelamente aos contornos circulares da seção transversal. Estas tensões tangenciais podem causar fratura vertical (RUNDQUIST; VERSLUIS, 2006).

Os retentores fundidos, apesar de serem morfologicamente semelhantes ao canal radicular, apresentam alta taxa de fracasso clínico, que foi explicada por promoverem ação de cunha (GOERIG; MUENINGHOFF, 1983; SORENSEN; MARTINOFF, 1984), que resulta em aumento de tensões.

Para resistir ao efeito cunha, foi idealizada a férula, propiciada pelo núcleo ou pela coroa, que tende a produzir o abraçamento da estrutura dental em torno do pino, o que dificultaria a intrusão da cunha e se contraporia ao aumento de perímetro propiciado por ela. A férula é um colar metálico de $360^{\circ}$ que circunda as paredes axiais da dentina remanescente (SORENSEN; ENGELMAN, 1990).

Vários estudos (ASSIF et al., 1993; PIERRISNARD et al., 2002; ZHI-YUE; YUXING, 2003) confirmam que a férula cervical cria um efeito positivo na redução da concentração de tensões na junção dentina-núcleo e ajuda a manter a integridade do selamento do cimento na coroa (LIBMAN; NICHOLLS, 1995).

Embora alguns autores recomendem uma altura mínima coronária de 1,5 a 2 mm (MORGANO, 1996; MORGANO; BRACKETT, 1999), Aykent et al. (2006) e Sorensen e Engelman (1990) demonstram que bastaria $1 \mathrm{~mm}$ de férula para aumentar significantemente os valores de resistência a fratura. 
Contudo, um dos problemas fundamentais nesses elementos é a falta de dentina remanescente saudável para reter as restaurações (ASSIF; GORFIL, 1994).

Barkhordar, Radke e Abbasi (1989) e Morgano e Brackett (1999) enfatizam que o aumento de coroa clínica ou a extrusão ortodôntica devem ser praticados em dentes severamente comprometidos, mediante exposição adicional de raiz, a fim de se estabelecer a férula. Na opinião dos autores, se estes procedimentos forem impraticáveis, indica-se a extração do dente. Pegoraro (1999) recomenda a confecção do núcleo estojado para proteger paredes fragilizadas da raiz.

Dentes posteriores restaurados com retentor intra-radicular podem estar sujeitos também a esforços de alavanca sempre que solicitados excentricamente em movimentos excursivos.

O contato oclusal no lado de trabalho em movimentos excursivos de lateralidade pode atingir a cúspide vestibular em dentes posteriores, gerando força de alavanca sobre as raízes envolvidas, que servem de guia para esses movimentos.

Os retentores intra-radiculares podem estar sujeitos também a forças rotacionais ou de torção, sempre que solicitados clinicamente através de contatos funcionais cúspide crista marginal, ou seja, relação de dente a dois dentes (COHEN et al., 1995; HEMMINGS; KING; SETCHELL, 1991; RUEMPING; LUND; SCHNELL, 1979; TJAN; MILLER, 1984).

Os contatos oclusais nas cristas marginais dos pré-molares superiores podem gerar torque que tende a girar a raiz sobre seu longo eixo. Por esta razão é extremamente importante que tenhamos em mente o uso de retentores que ofereçam maior segurança ao remanescente radicular em qualquer situação de esforço mecânico a que a raiz esteja submetida. 
Pinos pré-fabricados apresentam baixa resistência a forças de torção sobre o longo eixo devido à ausência de um travamento coronário anti-rotacional nesse sentido. Esta trava pode ser dada pelo núcleo, mediante um preenchimento na porção coronária do retentor (KURER; COMBE; GRANT, 1977), ou outros tipos de aparatos anti-rotacionais como: travas dentinárias paralelas ao pino, núcleo estojado e travas verticais no terço cervical da raiz incorporadas ao pino (HEMMMINGS; KING; SETCHELL, 1991), ou pelo uso de núcleos fundidos modelados direta ou indiretamente, individualizados pela anatomia do conduto radicular.

A forma da trava anti-rotacional deve conferir resistência a forças torsionais sem aumentar a taxa de fratura de dentes, devido ao aumento de tensões no local. Segundo Hemmmings, King e Setchell (1991), a forma da trava anti-rotacional que utiliza trava vertical restrita ao terço cervical pode induzir tensões e os melhores resultados foram apresentados pelo núcleo estojado.

Os retentores intra-radiculares também podem estar sujeitos a forças verticais durante função mastigatória através de contatos funcionais cúspide crista marginal.

Forças verticais (nas cristas marginais) dos pré-molares superiores podem gerar forças de alavanca proximal sobre as raízes envolvidas. Standlee, Caputo e Hanson (1978) sugeriu que a espessura da parede dentinária na secção transversal da raiz é importante para resistir a forças laterais.

Segundo Contin, Mori e Campos (2002) e Tjan e Wang (1985) o modelo de retentor intra-radicular com espelho perpendicular ao eixo da raiz previne a intrusão do núcleo no canal, o que promove o efeito espelho, que minimizaria a intrusão da cunha. O termo "espelho" é utilizado ao se referir à base do núcleo que fica em contato com o topo radicular, na intersecção do pino com o núcleo. Neste trabalho foi utilizada a mesma nomenclatura utilizada por estes autores que dividem o retentor 
intra-radicular em pino (parte do retentor que fica alojada dentro do canal), núcleo (parte do retentor que substitui a porção coronária perdida do dente), estojo (parte do retentor que circunda e abraça a raiz) e espelho.

Todos estes efeitos decorrentes de diferentes carregamentos associados a deficiências na preservação da estrutura dentária aumentam o risco de fratura. 


\section{PROPOSIÇÃO}

O objetivo deste estudo foi analisar a distribuição de tensões em função do formato da férula e do carregamento, em modelos que representam um segundo pré-molar superior restaurado com retentor intra-radicular fundido, comparativamente com a distribuição de tensões no mesmo dente hígido. Foram avaliadas três alturas de férula e três larguras de espelho, e os carregamentos simulados foram os seguintes:

a) Carregamento oblíquo $\left(45^{\circ}\right)$ distribuído na cúspide vestibular e na cúspide lingual, com a resultante paralela ao longo eixo do dente, com o objetivo de avaliar o efeito cunha.

b) Carregamento oblíquo $\left(45^{\circ}\right)$ distribuído na crista transversal da cúspide vestibular, com o objetivo de avaliar o efeito alavanca vestibular.

c) Carregamento paralelo ao longo eixo do dente, distribuído na crista marginal mesial, com o objetivo de avaliar o efeito alavanca proximal.

d) Carregamento oblíquo $\left(45^{\circ}\right)$ direcionado para vestibular, distribuída na crista marginal mesial, com o objetivo de avaliar o efeito do momento que tende a girar sobre o longo eixo (torção). 


\section{MATERIAL E MÉTODOS}

A análise pelo método dos elementos finitos é realizada em três etapas distintas: Pré-Processamento, Processamento e Pós-Processamento. A seguir descrevem se detalhadamente essas fases.

\subsection{Pré-Processamento}

4.1.1 Construção do modelo de dente hígido

Foi gerado um modelo de um dente higido e de suas estruturas de sustentação no programa MSC.PATRAN (The MacNeal-Schwendler Corporation USA), versão 2005r2. Sobre esse modelo foram realizadas modificações para a criação de novos modelos com retentor intra-radicular.

O modelo do segundo premolar superior hígido foi confeccionado com comprimento total de $21,4 \mathrm{~mm}$, comprimento radicular de $14,1 \mathrm{~mm}$, largura mesiodistal de 5,0 mm e largura vestíbulo-lingual de $8,5 \mathrm{~mm}$ no colo da raiz, dimensões médias encontradas por Cantisano, Palhares e Santos (1987). Também foram usados os dados médios apresentados por Shillinburg e Grace (1973), referentes às medidas das espessuras de dentina nos sentidos mésio-distal e vestíbulo-palatino de quatro cortes horizontais realizados ao longo do eixo principal da raiz a partir da junção cemento-esmalte com intervalo de $3,5 \mathrm{~mm}$. A espessura da dentina no 
restante da raiz foi obtida pela interpolação de uma curva spline a partir dos quatro dados existentes, seguindo a anatomia da raiz.

As dimensões médias da polpa radicular foram obtidas por interpolação a partir dos dados apresentados por Green e Brooklyn (1960), que fornece o diâmetro médio do forame apical e por Shillinburg e Grace (1973), que fornece as dimensões médias na região cervical.

Para a confecção da geometria da coroa clínica a espessura de esmalte e dentina coronária foram baseadas nos dados apresentados por Shillinburg e Grace (1973), por meio de cortes de intervalo de $1 \mathrm{~mm}$, por Cantisano, Palhares e Santos (1987) e por Ueti, Todescan e Gil (1997). A altura da cúspide vestibular foi considerada maior que a cúspide lingual em 0,9 mm, como corresponde aos segundos pré-molares superiores, conforme Shillinburg, Kaplan e Grace (1972).

As dimensões da câmara pulpar foram baseadas nos dados apresentados por Cantisano, Palhares e Santos (1987), que apresentam a altura da coroa; por Shillinburg e Grace (1973), que apresentam a espessura vertical de dentina e de esmalte a partir da câmara; por Ueti, Todescan e Gil (1997), que apresentam a espessura de dentina e esmalte em um corte vestíbulo-lingual.

Para elaboração das estruturas de sustentação, as dimensões anatômicas do osso cortical e esponjoso foram baseadas em imagem de corte vestíbulo-lingual da região do pré-molar superior apresentada por Berkovitz, Holland e Moxham (2004). Esta imagem foi digitalizada em um scanner de alta resolução de 4800 x 4800 dpi, HP SCANJET 8250 (Hewlett Packard). Em função do tamanho do objeto a ser digitalizado, a imagem pode ser digitalizada com uma resolução de 9600 x 9600 dpi. As dimensões vestíbulo-lingual do osso cortical e esponjoso foram medidas através do programa DigXY 1.2 (Thunderhead Engineering Consultants, Inc., USA), 
desenvolvido para digitalizar dados de bitmaps, amplamente utilizado para digitalizar coordenadas $\mathrm{X}, \mathrm{Y}$ de gráficos, Figura 4.1.
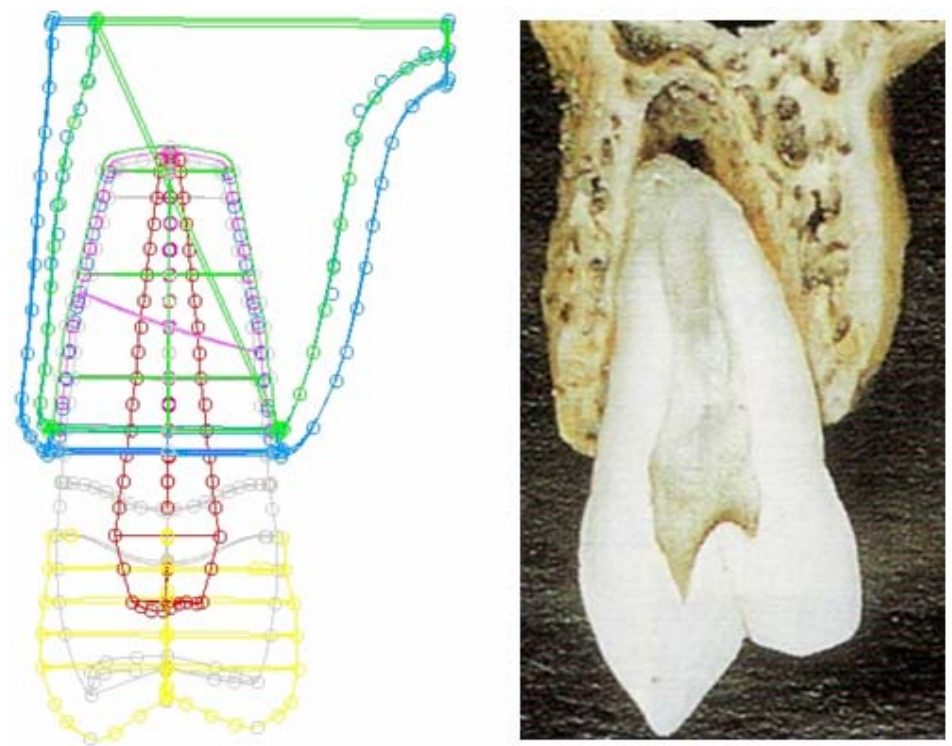

Figura 4.1 - Isocurvas do osso cortical e esponjoso do modelo e imagem digitalizada

A lâmina dura foi representada como uma camada de espessura uniforme (0,25 mm) com propriedades mecânicas iguais ao osso cortical, conforme dimensões médias obtidas através do programa DigXY 1.2 (Thunderhead Engineering Consultants, Inc., USA) em imagens radiográficas, Figura 4.2.
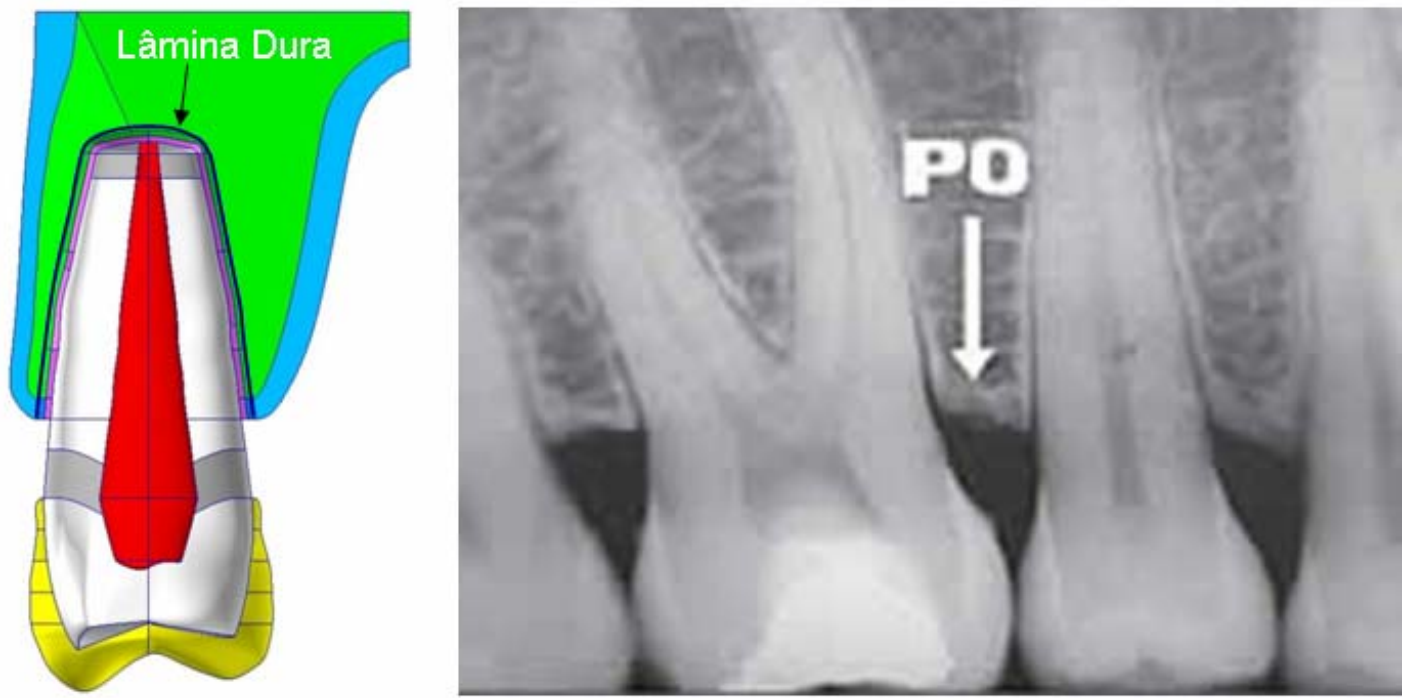

Figura 4.2 - Imagem radiográfica e superfície da lâmina dura do modelo 
O ligamento periodontal foi simulado como uma camada de espessura uniforme $(0,25 \mathrm{~mm})$ entre dente e osso (LEE; HUANG; LIN, 2000; REES; JACOBSEN, 1997).

\subsubsection{Construção dos modelos com retentor intra-radicular}

Para os modelos que representaram retentor intra-radicular, foram utilizados como base o modelo do dente hígido e as estruturas de sustentação já elaboradas. Nestes modelos foram realizadas modificações especificas na região correspondente à polpa e à dentina, nos locais correspondentes ao núcleo estojado e à da coroa metalo-cerâmica.

A dimensão da polpa dentária foi ampliada para reproduzir a etapa endodôntica de acesso, preparo biomecânico e obturação do canal radicular ${ }^{1}$.

A coroa metalo-cerâmica foi representada com o mesmo contorno do esmalte, sendo espessura, em média, de 1,5 $\mathrm{mm}$ na face vestibular, 1,2 $\mathrm{mm}$ na face lingual, $1,0 \mathrm{~mm}$ na face proximal e $2,0 \mathrm{~mm}$ na face oclusal, com um término em chanfro em torno do núcleo. A espessura mínima do metal (NiCr) na restauração metalocerâmica foi 0,3 mm, de acordo com Yamamoto (1985).

\footnotetext{
${ }^{1}$ Foi simulado um tratamento endodôntico, com instrumentos manuais (conicidade de 0,02 mm). Uma vez que o forme apical se encontra, em média, com diâmetro de $0,3 \mathrm{~mm}$ neste dente (Green e Brooklyn, 1960), seleciona-se um instrumento que se ajuste no comprimento de patência do canal ( $\mathrm{CPC}=0,3 \mathrm{~mm}$, lima $\mathrm{K} \# 30$ ). A limpeza do forame é completada com um instrumento de calibre imediatamente superior ao primeiro, que se ajustou no CPC (lima K\#35, 0,35 mm). Preparo apical: recua $1 \mathrm{~mm}$ e aumenta 1 vez o diâmetro $(C T=0,40 \mathrm{~mm}$, lima $\mathrm{k} \# 40)$. O diâmetro destes instrumentos aumenta de $0,05 \mathrm{~mm}$, até o número 60 . A partir deste número, foi simulado o preparo do terço médio e cervical com Gattes Glidden 2 (diâmetro $90 \mathrm{~mm}$ ), Gattes Glidden 3 (diâmetro 1,10 mm) e Gattes Glidden 4 (diâmetro 1,30 mm).
} 
Todos os modelos com retentor intra-radicular apresentaram as mesmas características em relação às estruturas de sustentação, coroa metalo-cerâmica, espessura de cimento e selamento apical (Figura 4.3).
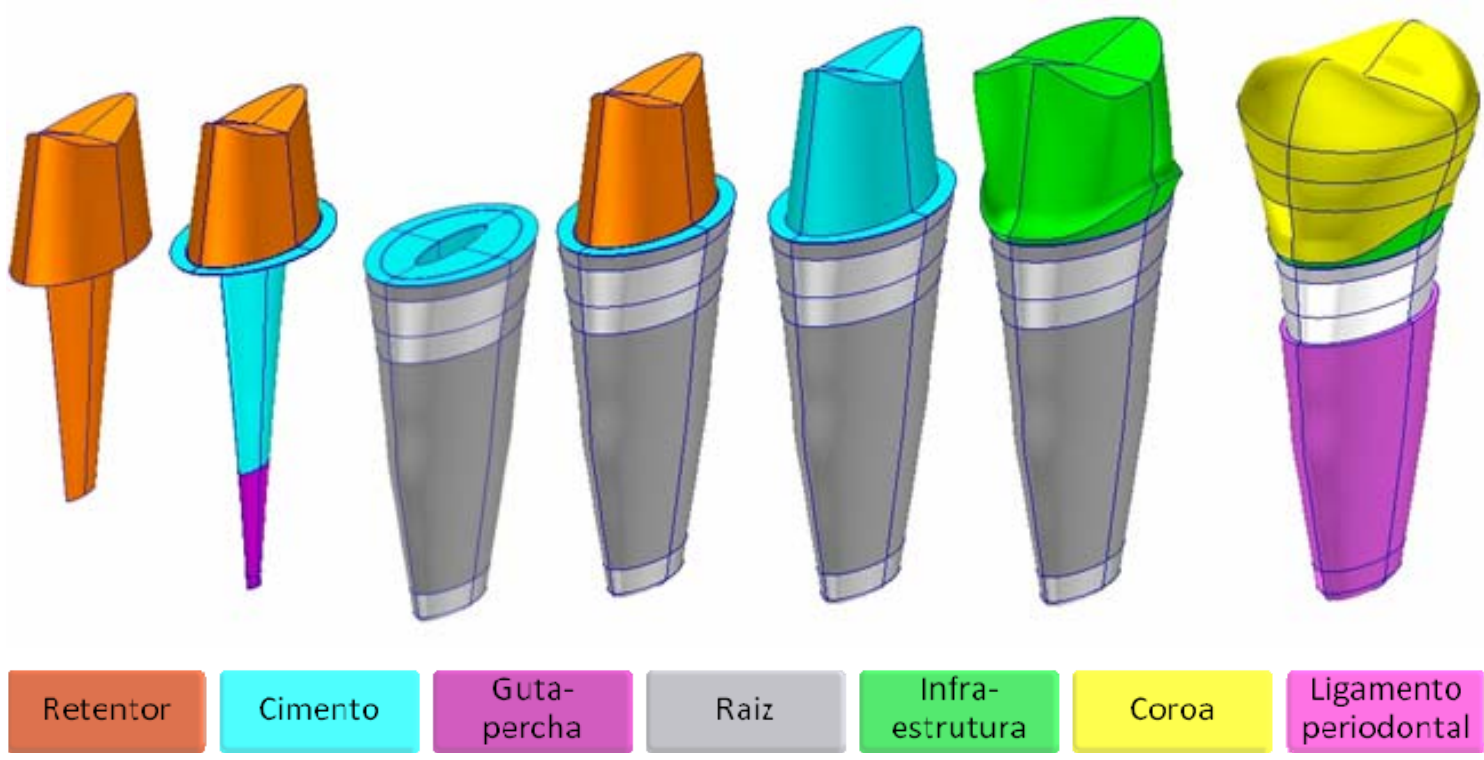

Coroa periodontal

Figura 4.3 - Estruturas dos modelos com retentores intra-radiculares

Foi representado o cimento de fosfato de zinco, normalmente usado para cimentação da coroa e do retentor intra-radicular, com espessura de 50 a $100 \mu \mathrm{m}$ (0,05 a 0,10 mm), de acordo com Anusavice (1998) e Shillingburg Jr. et al. (1998).

A altura de guta-percha foi de $5 \mathrm{~mm}$, seguindo especificações (de 3 a $5 \mathrm{~mm}$ ) de Colman, (1979); Deutsch, Musicant e Cohen (1997); Morgano (1996) e Sapone e Lorencki (1981).

Para confecção dos modelos com retentor intra-radicular, em quatro modelos variou-se a linha de terminação do preparo do núcleo estojado e em um modelo simulou núcleo simples (apenas com espelho, sem férula), mantendo-se a mesma restauração coronária.

A largura e a altura do estojo (porção do retentor que circunda a raiz) foram determinadas como uma proporção da espessura de dentina radicular encontrada na 
região da junção cemento-esmalte no lado lingual $(1,85 \mathrm{~mm})$, dividindo-se por três terços. Por outras palavras, temos estojos variando de 0,62 largura de $\times 0,62$ de altura a 1,34 x 1,34 mm (Figura 4.4).

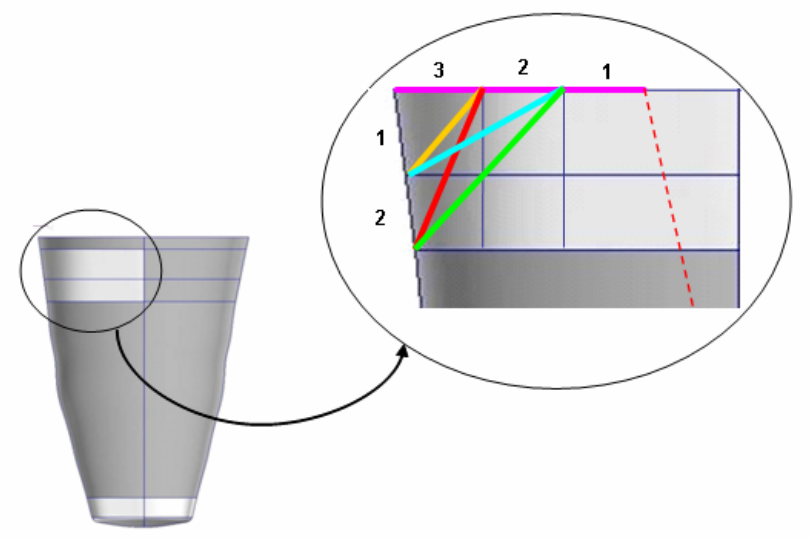

\begin{tabular}{c|c}
\hline $\begin{array}{l}\text { Bisel do } \\
\text { estojo }\end{array}$ & Código \\
\hline A & E2A1 \\
B & E2A2 \\
C & E1A1 \\
D & E1A2 \\
E & E2A0 \\
\hline
\end{tabular}

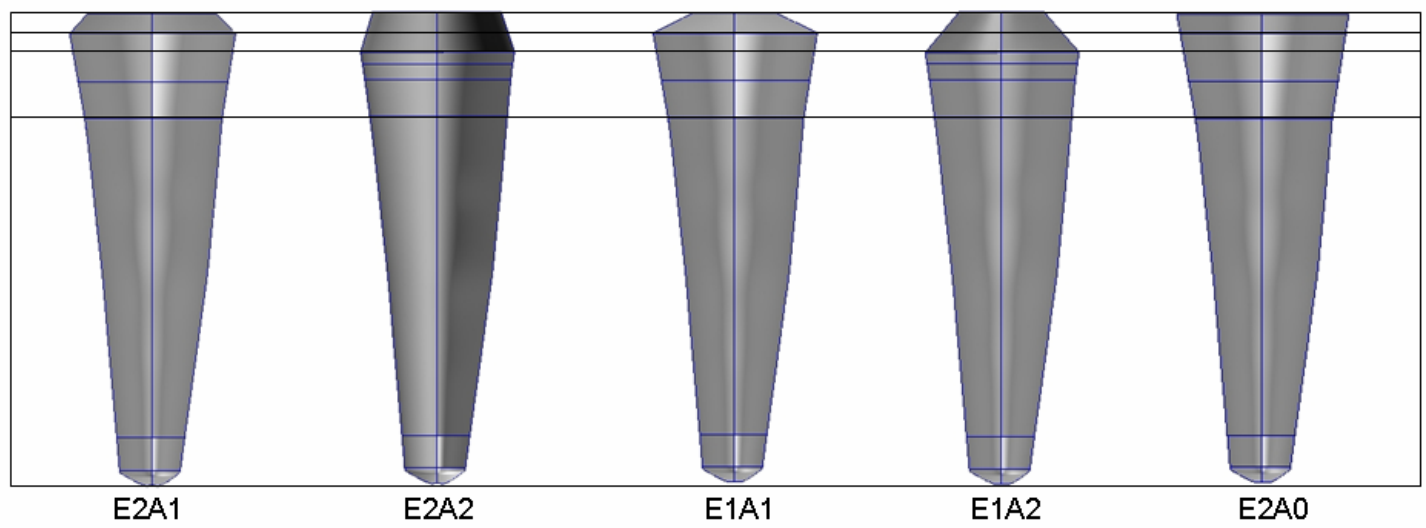

Figura 4.4 - Características diferenciais da dentina radicular

\subsubsection{Geração da malha de elementos finitos}

A partir das superfícies das estruturas confeccionadas, foram geradas as malhas superficiais com elementos triangulares de topologia plana linear Tri3, ou seja, 1 face contendo 3 arestas, com 1 nó em cada uma das extremidades das arestas. Foram utilizados elementos de arestas de tamanho de 0,05 mm, em regiões de grande curvatura, de pequeno tamanho ou transição entre estruturas, até arestas 
de 0,30 $\mathrm{mm}$, em áreas de pequena curvatura, de grande tamanho ou distantes de transição entre estruturas.

A seguir, procedeu-se à geração da malha volumétrica com elementos tetraédricos de topologia Tet4, ou seja, elemento piramidal de 4 faces contendo 6 arestas, com 1 nó em cada uma das extremidades das arestas. Foram utilizados elementos de arestas de tamanho de 0,05 $\mathrm{mm}$ a $0,30 \mathrm{~mm}$, compatível com o procedimento utilizado anteriormente (Figura 4.5). 

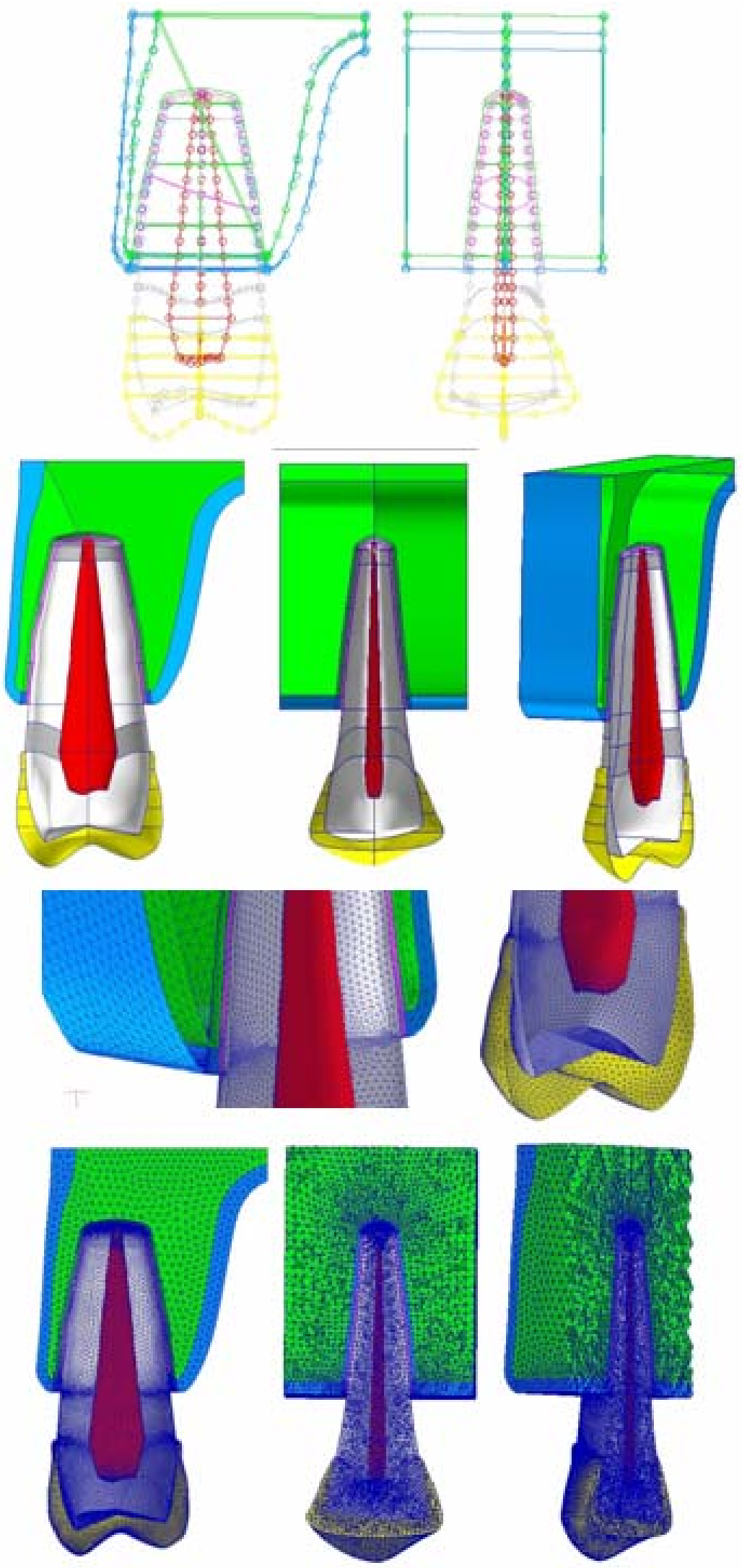

Figura 4.5 - Geração de malha superficial e volumétrica do modelo hígido 
O grau de discretização dos modelos foi estabelecido a partir de estudos de convergência dos resultados, da capacidade do computador utilizado nas análises e de testes de verificação de elementos distorcidos. A discretização acima detalhada correspondeu à melhor relação custo-benefício suportada por um computador Pentium Dual-Core com processador de $1.7 \mathrm{GHz}$, disco rígido de $160 \mathrm{~Gb}$ e $2 \mathrm{~Gb}$ de memória RAM.

Apesar de que os elementos hexaédricos (6 faces) sejam melhores que os tetraédricos no que se refere à solução das equações e resultados, não foram utilizados devido à complexidade da geometria analisada, na qual apareceriam elementos distorcidos, o que compromete a discretização da geometria e a análise dos resultados.

A malha obtida pela discretização dos diferentes modelos elaborados apresentou os dados presentes na Tabela 4.1.

Tabela 4.1 - Características das malhas obtidas para os modelos gerados

\begin{tabular}{l|c|c|c}
\hline Código & Características diferenciais & $\begin{array}{c}\text { Número } \\
\text { de nós }\end{array}$ & $\begin{array}{c}\text { Número de } \\
\text { elementos }\end{array}$ \\
\hline H & $2^{0}$ premolar superior hígido & 179.403 & 1.109 .929 \\
E2A1 & Espelho 2 e Altura férula 1 & 193.034 & 1.226 .486 \\
E2A2 & Espelho 2 e Altura férula 2 & 179.430 & 1.142 .542 \\
E1A1 & Espelho 1 e Altura férula 1 & 189.438 & 1.200 .778 \\
E1A2 & Espelho 1 e Altura férula 2 & 180.720 & 1.148 .853 \\
E2A0 & Espelho 2 e Altura férula 0 & 184.750 & 1.175 .175 \\
\hline
\end{tabular}

4.1.4 Definição das propriedades dos materiais

A natureza heterogênea e anisotrópica da estrutura dental e dos tecidos de suporte foi simplificada para facilitar a análise da resposta estrutural dos 
componentes na modelagem. Todas as estruturas constantes no modelo foram representadas como isotrópicas, homogêneas e linearmente elásticas, caracterizadas pelo módulo de elasticidade (E) e coeficiente de Poisson (v).Os valores utilizados são apresentados na Tabela 4.2. As interfaces entre a estruturas foram representadas como perfeitamente unidas.

Tabela 4.2 - Propriedades mecânicas dos materiais e estruturas anatômicas

\begin{tabular}{|c|c|c|c|}
\hline Estrutura / Material & $\begin{array}{c}\text { Módulo de } \\
\text { Elasticidade } \\
\text { (GPa) }\end{array}$ & $\begin{array}{l}\text { Coeficiente } \\
\text { de Poisson }\end{array}$ & Referência \\
\hline Polpa & 0,02 & 0,45 & Farah e Craig (1974) \\
\hline Dentina & 18,60 & 0,31 & Ko et al. (1992) \\
\hline Esmalte & 41,00 & 0,30 & Ko et al. (1992) \\
\hline Ligamento periodontal & 0,0689 & 0,45 & Weinstein, Klaawitter e Cook \\
\hline Osso Cortical & 13,70 & 0,30 & Veiga (1996) \\
\hline Osso Esponjoso & 1,37 & 0,30 & Veiga (1996) \\
\hline Guta-percha & 0,00069 & 0,45 & Friedman et al.(1975) \\
\hline $\mathrm{NiCr}$ & 188,00 & 0,33 & Vasconcellos (1999) \\
\hline Cimento Fosfato de Zinco & 13,00 & 0,35 & Powers, Farah e Craig (1976) \\
\hline Cerâmica Feldspática & 82,80 & 0,35 & Peyton e Craig (1963) \\
\hline $\begin{array}{l}\text { Retentor metálico fundido } \\
\text { (ILOR56: gold-alloy post) }\end{array}$ & 93,00 & 0,33 & Pegoretti et al. (2002) \\
\hline
\end{tabular}

\subsubsection{Definição das condições de fixação e carregamento}

Foram aplicadas as seguintes condições de fixação: no seio maxilar, restringiu-se a translação nas direções $x, y$ e $z$, e rotações nos eixos $x, y$ e $z$; nas extremidades mesial e distal do osso cortical e esponjoso, restringiu-se a translação na direção $(x)$ e rotações nos eixos y e z, conforme ilustrado na Figura 4.6. 


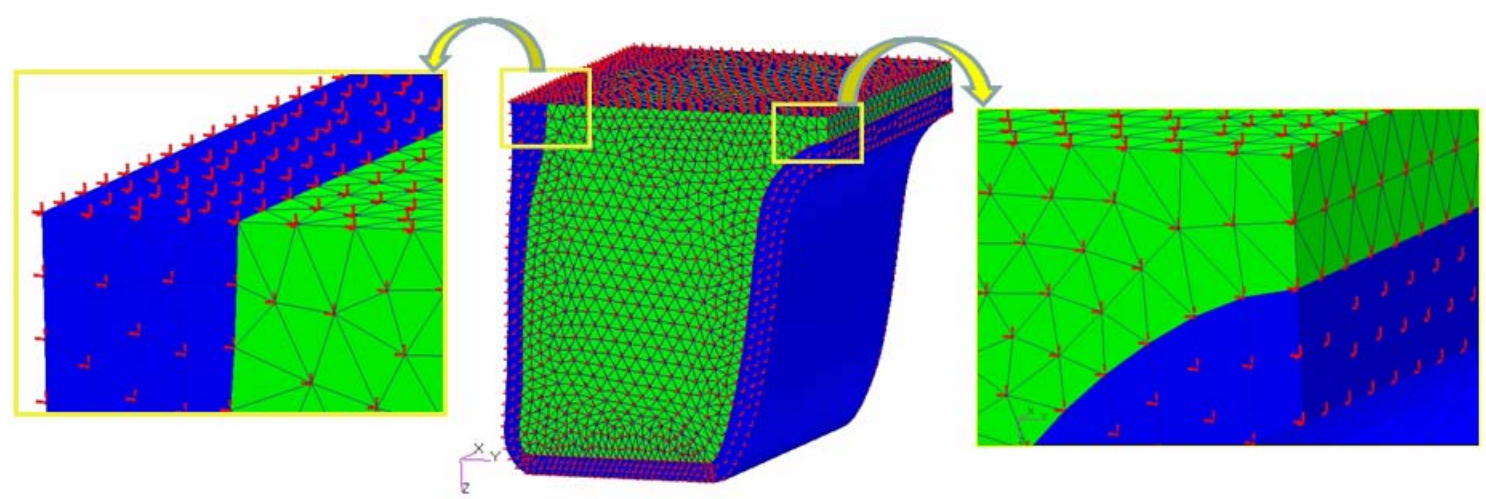

Figura 4.6- Ilustração das condições de fixação aplicadas

Foram aplicadas quatro condições de carregamento nas quais variou a inclinação e o local de aplicação de uma carga estática total de 291,36 N (FERRARIO et al., 2004).

Todos os modelos receberam carga distribuída por 38 pontos nodais, 19 dos quais em uma área de $0,85 \mathrm{~mm}^{2}$ na cúspide vestibular e 19 em uma área de $0,75 \mathrm{~mm}^{2}$ na cúspide lingual (KUMUGAl et al., 1999), com uma inclinação de $45^{\circ}$ (HO et al., 1994; HOLMES; DIAZ-ARNOLD; LEARY, 1996), mas com a resultante (291,36 N) paralela ao longo eixo do dente, com o objetivo de avaliar o efeito cunha (Figura 4.7 A).

Posteriormente, o modelo julgado com férula que melhor minimizou o efeito cunha (E1A2), assim como os modelos que representam dente hígido e restaurado com núcleo simples (apenas com espelho sem férula, E2A0) foram submetidos aos seguintes carregamentos:

(a) Carga oblíqua, com uma inclinação de 45, distribuída em 19 pontos nodais em uma área de $0,85 \mathrm{~mm}^{2}$ na crista transversal da cúspide vestibular, com o objetivo de avaliar o efeito alavanca vestibular (Figura $4.7 \mathrm{~B}$ ). 
(b) Carga com $0^{\circ}$ de inclinação distribuída por 19 pontos nodais em uma área de $0,80 \mathrm{~mm}^{2}$ na crista marginal mesial, com o objetivo de avaliar o efeito alavanca proximal (Figura $4.7 \mathrm{C}$ ).

(c) Carga oblíqua, com uma inclinação de $45^{\circ}$ direcionado para vestibular, distribuída por 19 pontos nodais em uma área de $0,80 \mathrm{~mm}^{2}$ na crista marginal mesial, com o objetivo de avaliar o efeito da torção sobre o longo eixo (Figura 4.7 D).

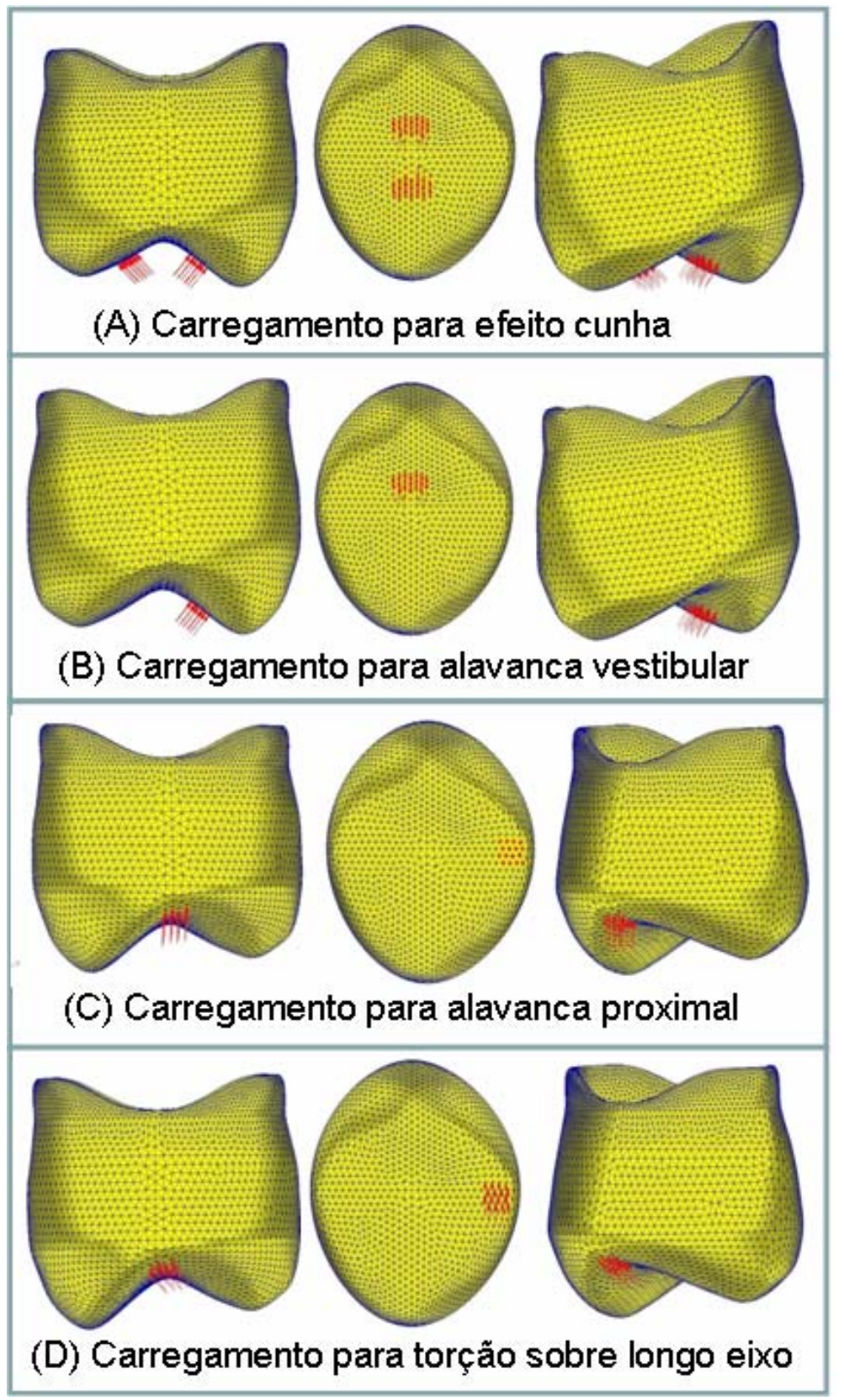

Figura 4.7 - Local do ponto de aplicação e orientação das cargas 


\subsection{Processamento}

O programa utilizado para análise foi o NASTRAN (The MacNeal-Schwendler Corporation - USA), versão 2005r1, em microcomputador Pentium Dual-Core com processador de $1.7 \mathrm{GHz}$, disco rígido de 160 Gb e 2 Gb de memória RAM.

\subsection{Pós-Processamento}

Previamente à realização da análise dos resultados, foi verificada a convergência dos resultados obtidos em todos os modelos em função de diferentes refinamentos da malha de elementos finitos, com procedimento $\mathrm{h}$ (aumento do número de elementos) e p (utilização de elementos de maior ordem de integração). Esta etapa consistiu em retornar à etapa de pré-processamento, realizar refinamentos consecutivos da malha e, posteriormente, ir para o módulo de processamento para resolver novamente o sistema de equações. Posteriormente, os resultados foram comparados entre diferentes procedimentos de refinamento da malha. Cuidado adicional foi tomado com relação ao refinamento da malha nas áreas de maior concentração de tensões evidenciadas nos modelos, evitando-se elementos distorcidos. Este procedimento é fundamental para um bom condicionamento do problema numérico (SORIANO, 2003).

Considerando que os resultados foram semelhantes (diferenças menor que 5\%), o processo foi dado como concluído pela convergência dos resultados e selecionado os modelos de menor custo computacional. 


\subsection{Análise dos resultados}

Os valores dos picos de tensão principal máxima ocorridos na dentina e no cimento foram comparados com valores de resistência à tração destes materiais, para avaliar se as cargas seriam potencialmente lesivas às estruturas estudadas. A Tabela 4.3 ilustra as resistências à tração, à compressão e cisalhamento das estruturas que foram avaliadas.

Tabela 4.3 - Resistência à tração, à compressão e ao cisalhamento e referências bibliográficas

\begin{tabular}{ll|c|c|c|c}
\hline Material & & $\begin{array}{c}\text { Resistência } \\
\text { à tração } \\
\text { (MPa) }\end{array}$ & $\begin{array}{c}\text { Resistência } \\
\text { à } \\
\text { compressão } \\
(\mathrm{MPa})\end{array}$ & $\begin{array}{c}\text { Resistência } \\
\text { ao } \\
\text { cisalhamento } \\
(\mathrm{MPa})\end{array}$ & Referência \\
\hline $\begin{array}{l}\text { Cimento } \\
\begin{array}{l}\text { Zinco } \\
\text { Dentina }\end{array}\end{array}$ & Fosfato de & 8,3 & - & - & $\begin{array}{r}\text { Powers et al. (1976) } \\
\text { Tanaka et al. (2003) } \\
\text { /O'Brien (1997) }\end{array}$ \\
\hline
\end{tabular}

Foi avaliada comparativamente a distribuição de tensões nas figuras que representam tensões agrupadas por faixas. A escala de tensões (que aparecem com diferentes cores nas figuras) não possui intervalos iguais, em função das tensões atuantes em cada grupo de modelos (diferentes tipos de carregamentos). Desta forma, uma única escala foi definida para todos os modelos (com exceção dos modelos com carregamento que gera cunha), com o objetivo de facilitar a comparação.

Avaliou-se também a orientação da tensão principal máxima na dentina. Avaliou-se ainda a tensão dos nós da intersecção da superfície dentinária com determinados planos de corte. Estes valores foram lançados em gráficos de tensão em função da distância a determinados nós arbitrários. Para padronizar o eixo da 
distância utilizou-se a relação "distância entre a origem escolhida e o nó correspondente, dividida pelo comprimento total da região avaliada". 


\section{RESULTADOS E DISCUSSÃO}

Devido à falta de informações na literatura corrente sobre quais seriam os fatores mais eficientes na férula (altura, largura, inclinação), neste estudo foi avaliada a influência da utilização de diferentes formatos da férula frente a diferentes tipos de carregamentos na distribuição de tensões de tração e compressão em modelos tridimensionais (3D). Os modelos que representam um dente hígido e um dente restaurado com retentor intra-radicular sem férula foram utilizados para fins de comparação.

\subsection{Efeito Cunha - Carregamento com resultante paralela ao longo eixo}

As figuras 5.1, 5.2 e 5.3 apresentam as tensões principais máximas. Na figura 5.1, uma vista em perspectiva de todas as estruturas; na 5.2 uma vista proximal do osso cortical e lâmina dura; na 5.3, em perspectiva da dentina. Na Figura 5.4 são apresentados os vetores de tensão compressiva e trativa nos nós de uma linha que percorre a superfície interna e externa da dentina radicular na intersecção com um plano de corte vestíbulo-lingual e outro plano mésio-distal.

Nas Figuras 5.1 e 5.2 todos os modelos responderam igualmente, como seria de esperar, o que pode ser interpretado como indicador de que todas as condições de contorno dos modelos foram corretamente escolhidas. As diferenças ficaram apenas na figura 5.3, mas são pequenas diferenças e apenas na região da dentina em contato com a férula. Os resultados obtidos com os modelos E2A1 e E1A1 
apresentaram padrão de distribuição de tensões semelhante, mas diferente dos modelos E2A2 e E1A2 (que apresentam alguma tração sob a férula, embora de valor muito baixo). No modelo $\mathrm{H}$, a região de dentina entre o osso e o esmalte apresenta alguma tração, mas a Figura 5.4 mostra que a direção não é totalmente tangencial (e não seria nociva, nem pela intensidade nem pela direção). Tensões semelhantes a esta aparecem em todos os outros modelos com retentor (imediatamente para apical da férula): não se pode esperar que sejam responsáveis por eventual fratura da raiz. Todos os modelos apresentam pico de compressão no ápice da raiz, mas com intensidade muito baixa quando comparada com a resistência à ruptura da dentina (ver Tabela 4.3). Aliás, as tensões principais máximas encontradas, tanto as de tração quanto as de compressão, são muito inferiores às de ruptura, o que leva a pensar que o carregamento longitudinal não representa perigo para a integridade do dente, nem mesmo quando restaurado com retentor intra-radicular fundido e submetido a carga elevada. A leve concentração de tensões encontrada ao redor do ápice do pino (Figura 5.4), embora seja concorde com os achados de Cailleteau, Rieger e Akin (1992), Davy, Dilley e Krejci (1981) e Reinhardt et al. (1983) não parece poder ser responsabilizada pela fratura longitudinal, pois a orientação e a intensidade não justificariam a fratura. Em nenhum ponto foram encontradas tensões de tração tangenciais à circunferência da secção transversal da raiz, sejam dirigidas paralelamente ao longo eixo do dente ou contidas no plano da secção.

O modelo E1A1 minimizou o efeito cunha, pois as tensões encontradas na dentina radicular sobre o estojo são compressivas (1 a $2 \mathrm{MPa}$ ), apesar de apresentar tensões trativas (1 MPa) na dentina radicular acima do ligamento periodontal.

Comparando-se o modelo E2A1 com o modelo E1A1 podemos concluir que o aumento na largura do estojo, mantendo-se a altura, foi importante no efeito protetor 
férula, pois as tensões compressivas aumentaram quatro vezes. O modelo E1A2 apresentou tensões compressivas na dentina radicular sobre o estojo (0,5 a $2 \mathrm{MPa})$ e tensões compressivas na dentina radicular acima do ligamento periodontal $(0,5 \mathrm{a}$ $2 \mathrm{~mm}$ ), face mesial e distal.

Por outro lado, ao ser feita uma comparação relativa entre os modelos carregados longitudinalmente, nota-se que entre o modelo E2A2 e o modelo E1A2 desaparece a tração na dentina em contato com a férula, o que pode ser atribuído ao aumento na largura do estojo, mantendo-se a altura. Esta característica confere ao desenho da férula alguma superioridade, pois podemos inferir que será mais difícil que o cimento se descole nessa região, já que não está submetido a tração (ver também a Figura 5.5). O modelo E1A2 também parece ter minimizado as tensões trativas na dentina radicular cervical (tensões compressivas de 0,5 a $2 \mathrm{MPa}$ ) e na dentina radicular próxima ao ligamento periodontal, seguido do modelo E1A1, E2A1 e E2A2. 

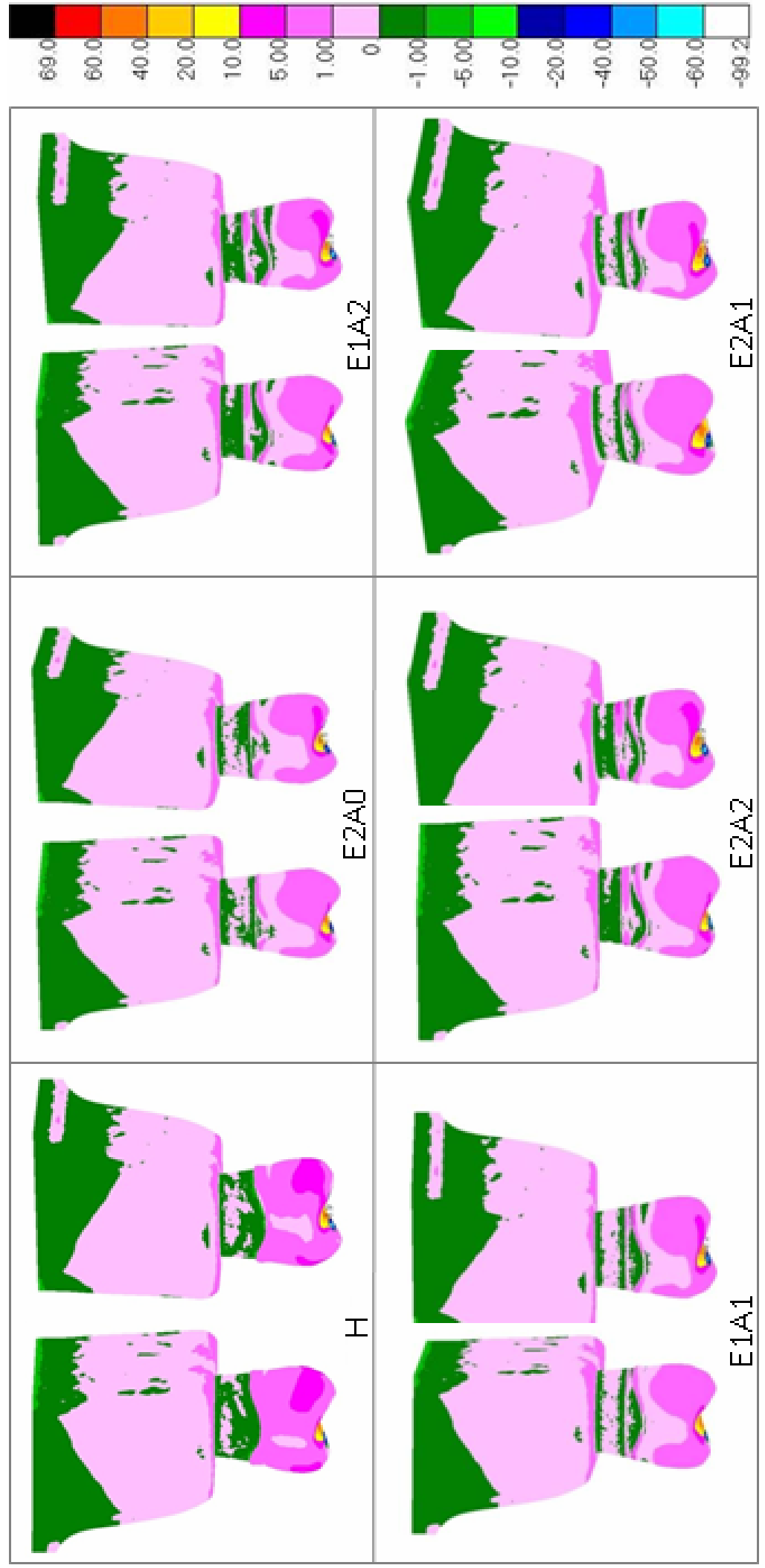

Figura 5.1 - Vista em perspectiva de todas as estruturas. Tensões principais máximas em todos os modelos carregados longitudinalmente 


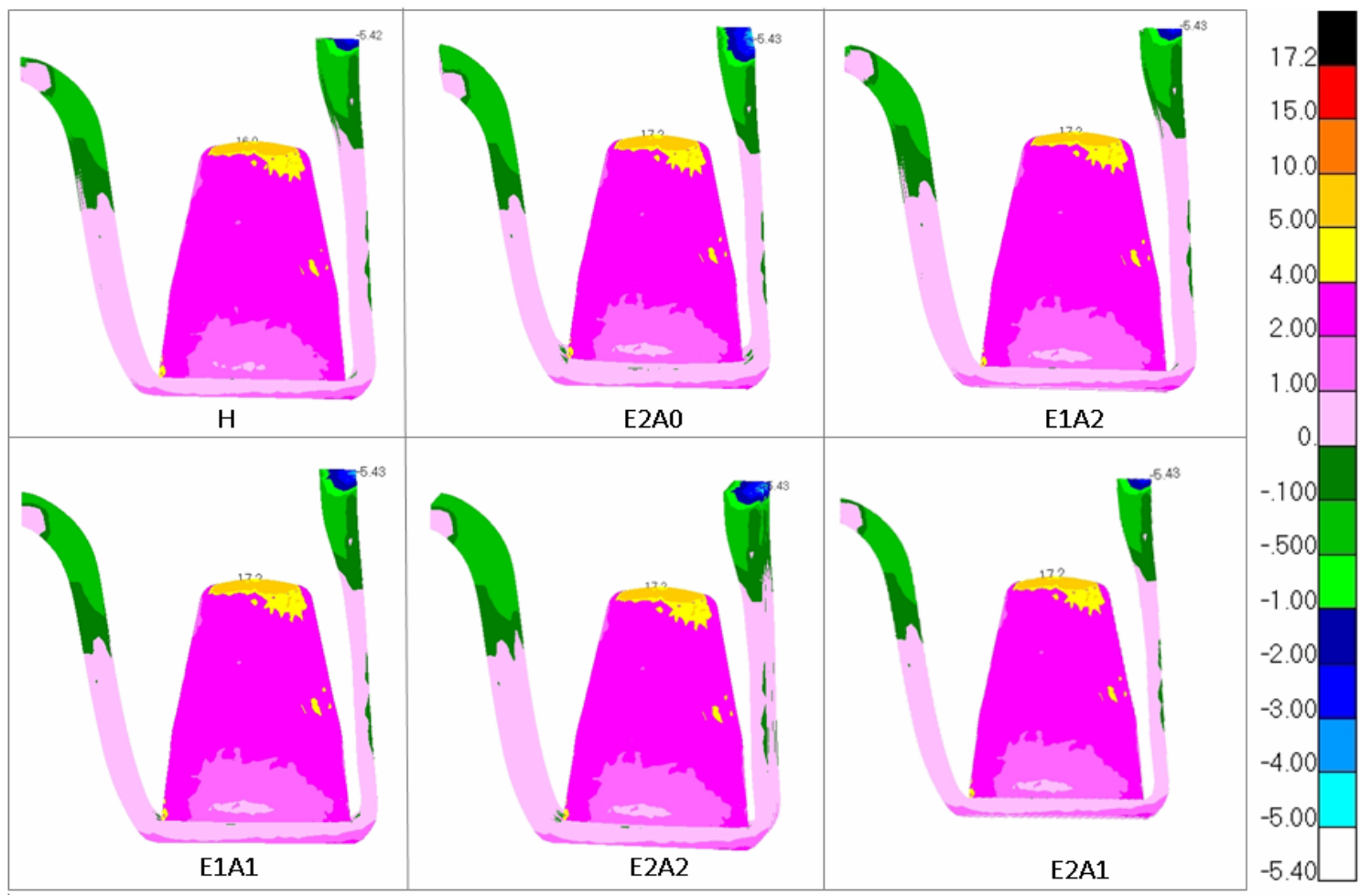

Figura 5.2 - Vista proximal do osso. Tensões principais máximas em todos os modelos carregados longitudinalmente 


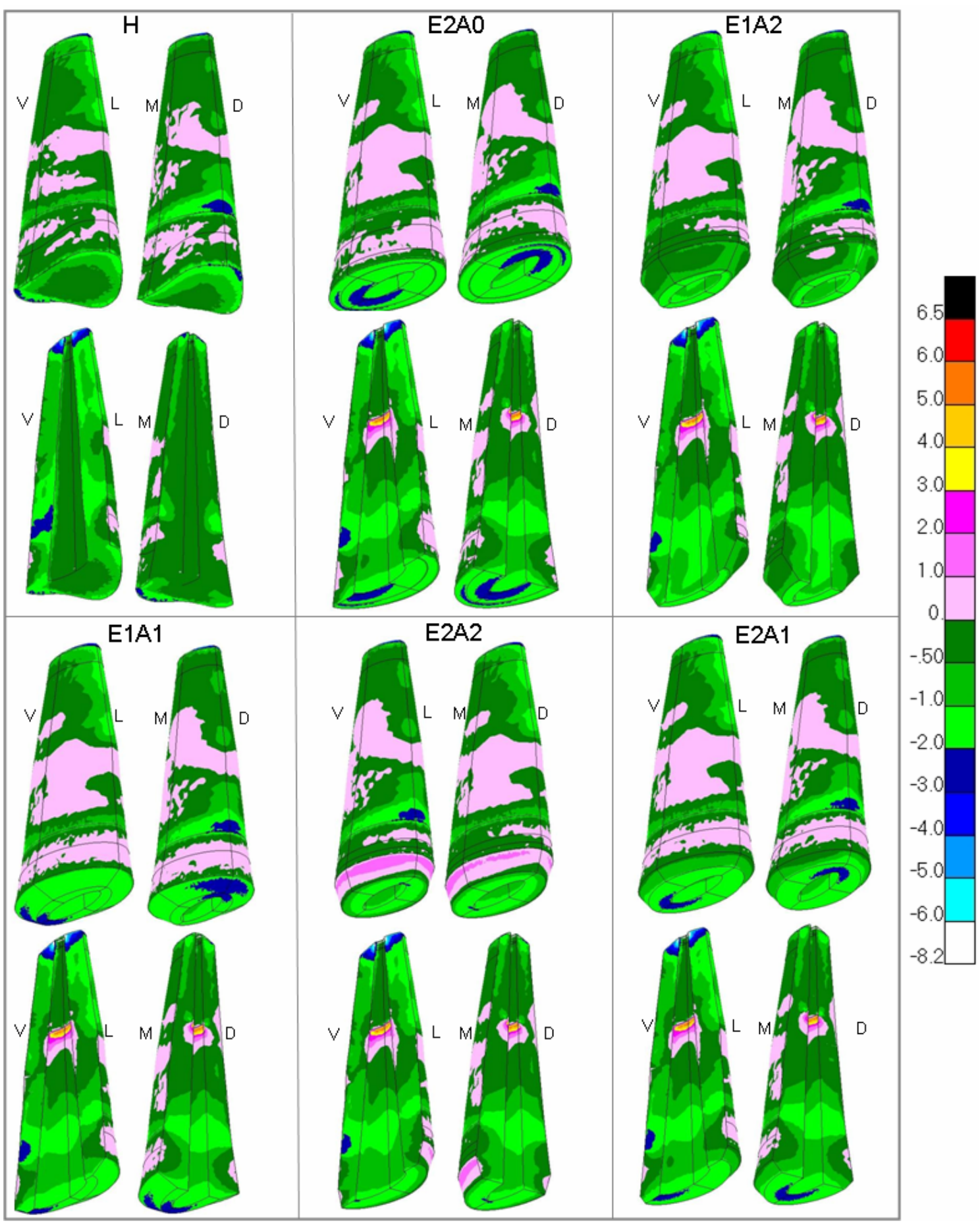

Figura 5.3 - Vista em perspectiva da dentina. Tensões principais máximas em todos os modelos carregados longitudinalmente 


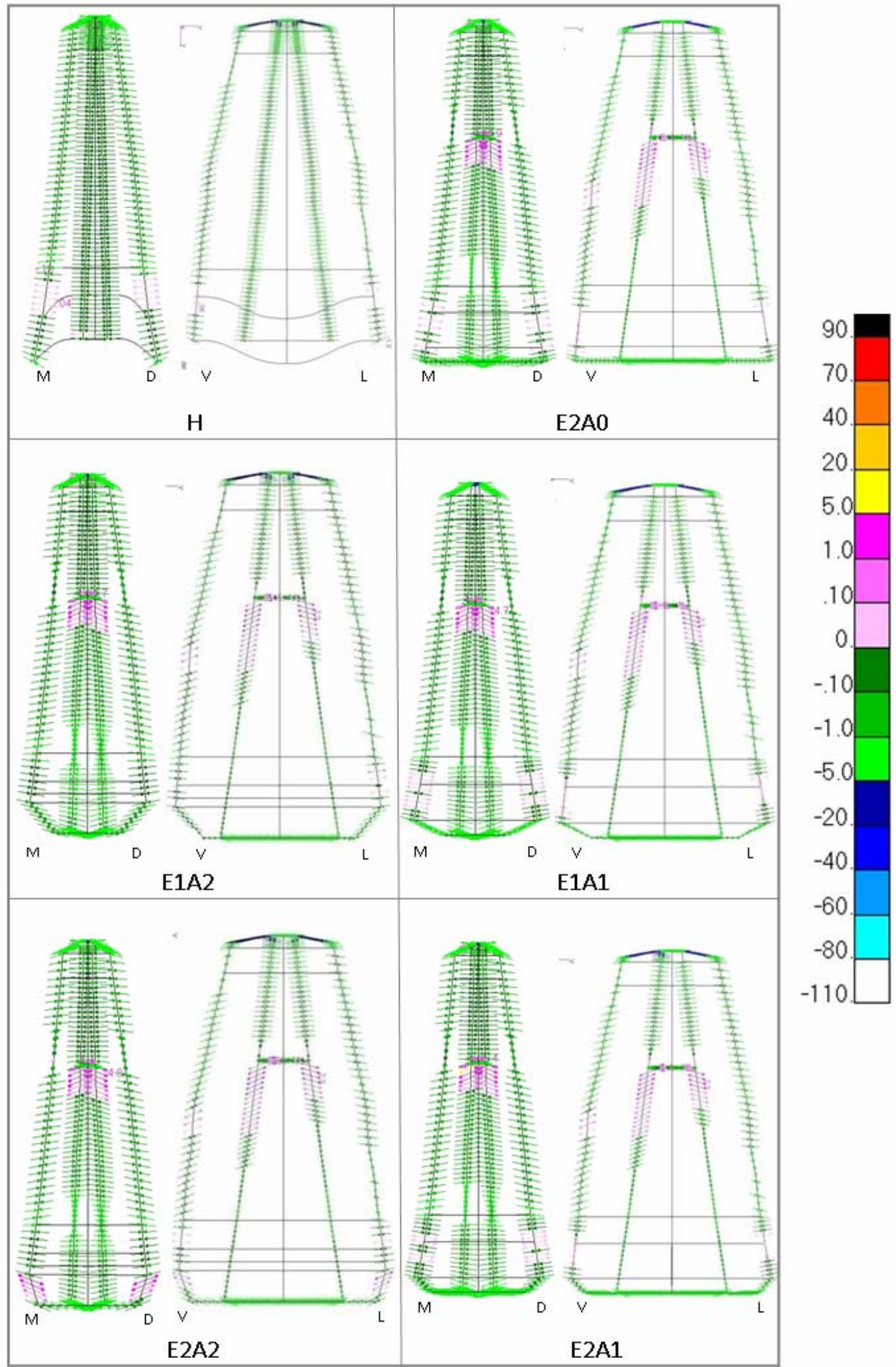

Figura 5.4 - Vetores resultantes das tensões principais máximas na superfície interna e externa da dentina radicular, corte vestíbulo-lingual e mésio-distal, respectivamente 
A Figura 5.5 corresponde a uma visão em perspectiva da distribuição das tensões principais máximas no cimento entre o retentor e a dentina, nos modelos carregados longitudinalmente. Os resultados obtidos com os modelos E1A1, E2A0 e E2A1 apresentaram padrão de distribuição de tensões semelhante no cimento abaixo da férula, mas diferentes do modelo E2A2, que mostra tensões de tração maiores (até $4 \mathrm{MPa}$ ), que pela direção (Figura 5.4) sugere maior tendência a descolar ou romper a camada de cimento na região, pois as tensões são significativamente maiores; mas a falha do cimento parece pouco provável quando comparamos os valores absolutos de tensão com a tensão necessária para a ruptura coesiva do cimento (Tabela 4.3).

Na Figura 5.6 é apresentada a tensão principal máxima na superfície externa da dentina radicular em função da posição relativa do nó na face vestibular, a partir do ápice para região cervical. A pequena defasagem das curvas parece corresponder a uma particularidade da construção do gráfico (abscissa adimensional e pequena variação do comprimento total entre os diferentes casos). Todas as curvas apresentam-se bastante semelhantes. Na região mais próxima da férula observam-se tensões de tração, mas em todos os modelos é muito próxima de zero. Não há diferenças significativas entre as tensões encontradas nos diferentes tipos de férula. 

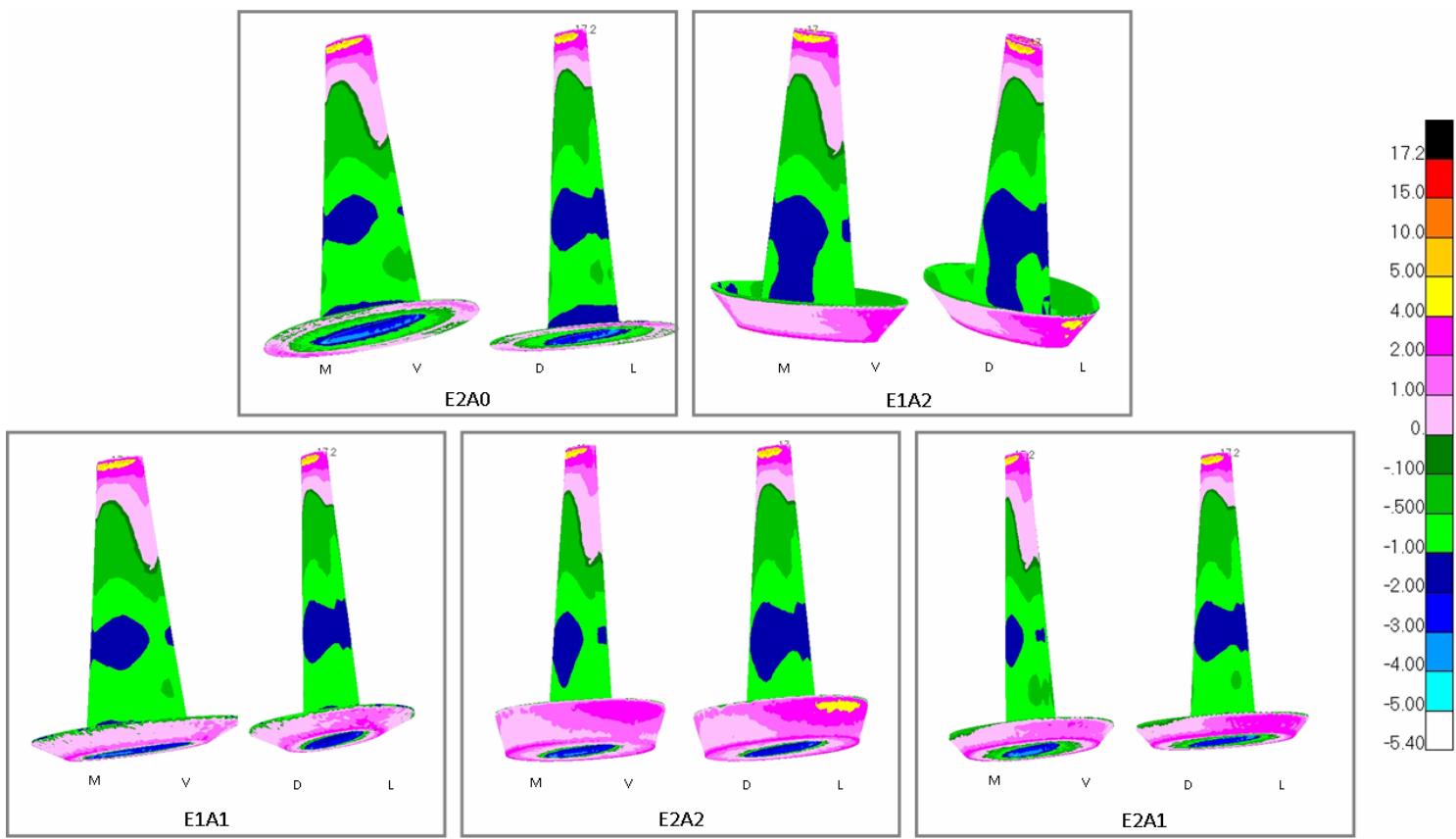

Figura 5.5 - Vista em perspectiva do cimento entre o retentor e a dentina. Tensões principais máximas em todos os modelos carregados longitudinalmente

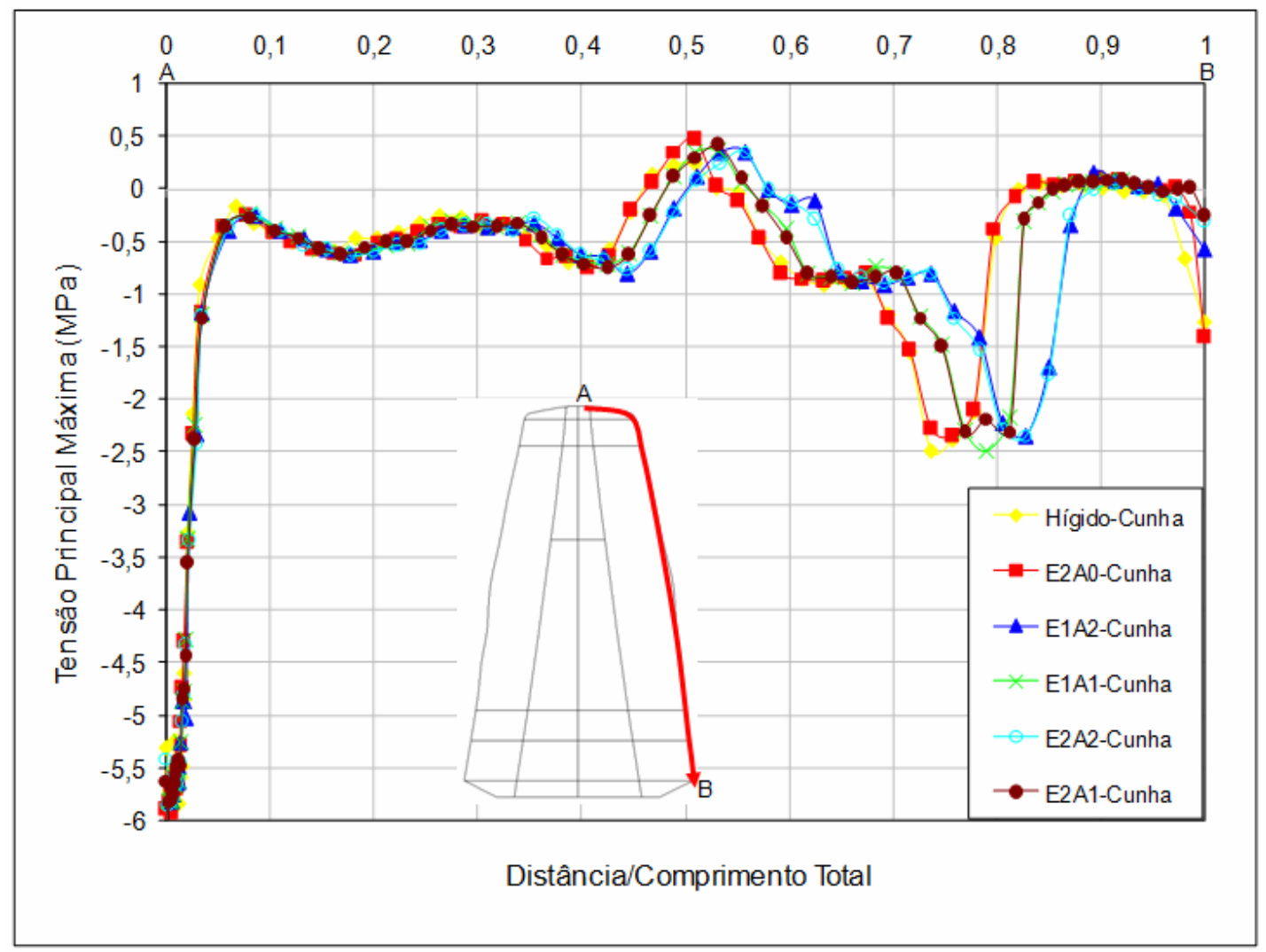

Figura 5.6 - Tensão principal máxima em superfície externa da dentina radicular 
Na Figura 5.7 é ilustrada a tensão principal máxima na dentina radicular interna. Observa-se que existe um comportamento similar de todos os casos, ou seja, o tipo de espelho ou férula não influiu nesta região. Observações importantes devem ser feitas neste gráfico: pela adesão ser perfeita, não é possível perceber um efeito cunha apreciável. O único local onde aparece alguma tração (Figura 5.4) é na região do ápice do pino, mas não tem direção tangencial a secção transversal.

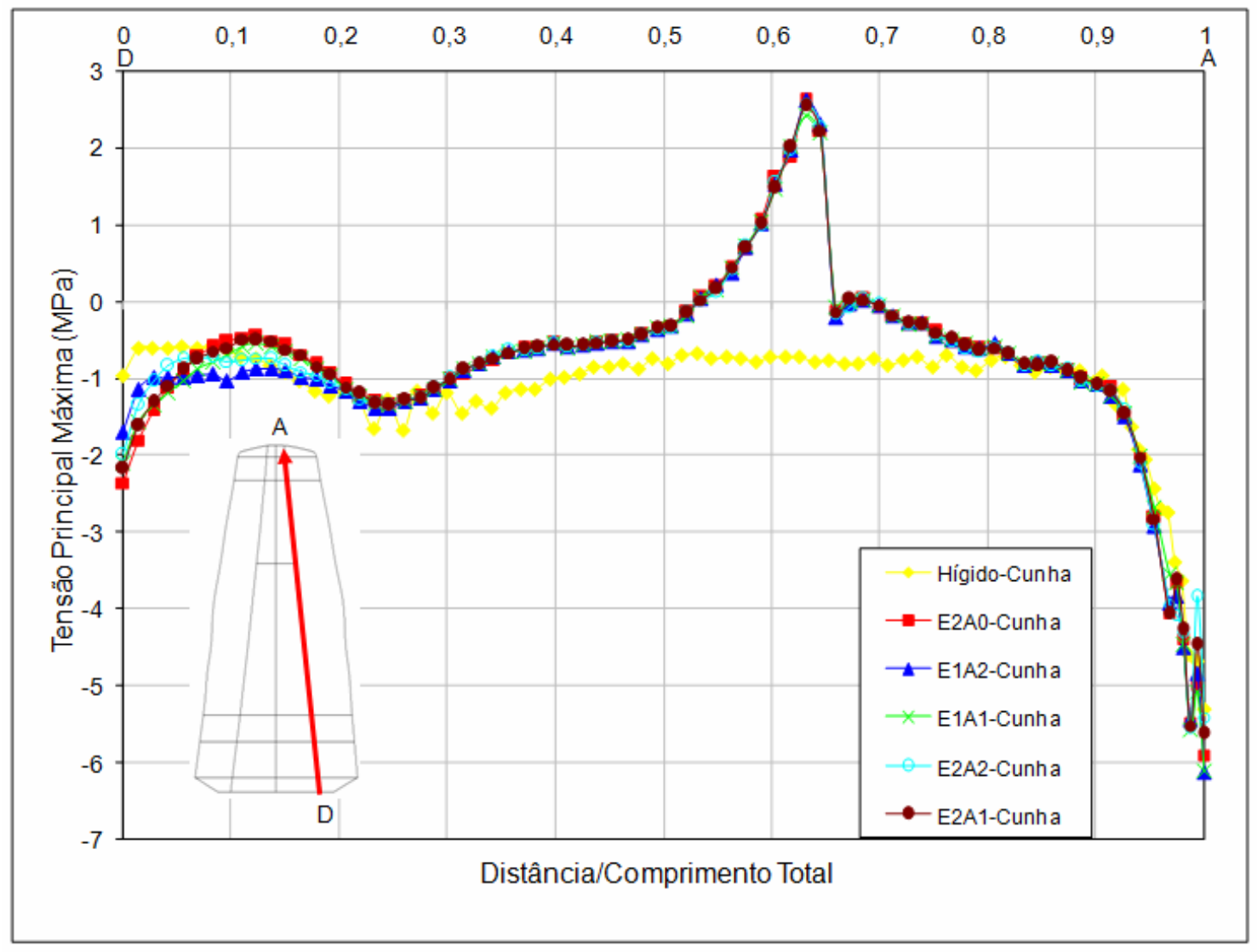

Figura 5.7 - Tensão principal máxima em dentina radicular interna

Na Figura 5.8 é ilustrada a tensão principal máxima no perímetro apical da dentina radicular sobre o ápice do pino. Pela adesão ser perfeita, as variações de tensões na dentina radicular, que podem ser atribuídas a variações no espelho/férula, parecem ser pouco importantes quando comparadas às variações 
inerentes à assimetria geométrica do modelo (as paredes dentinárias não apresentam a mesma espessura nos quadrantes simétricos).

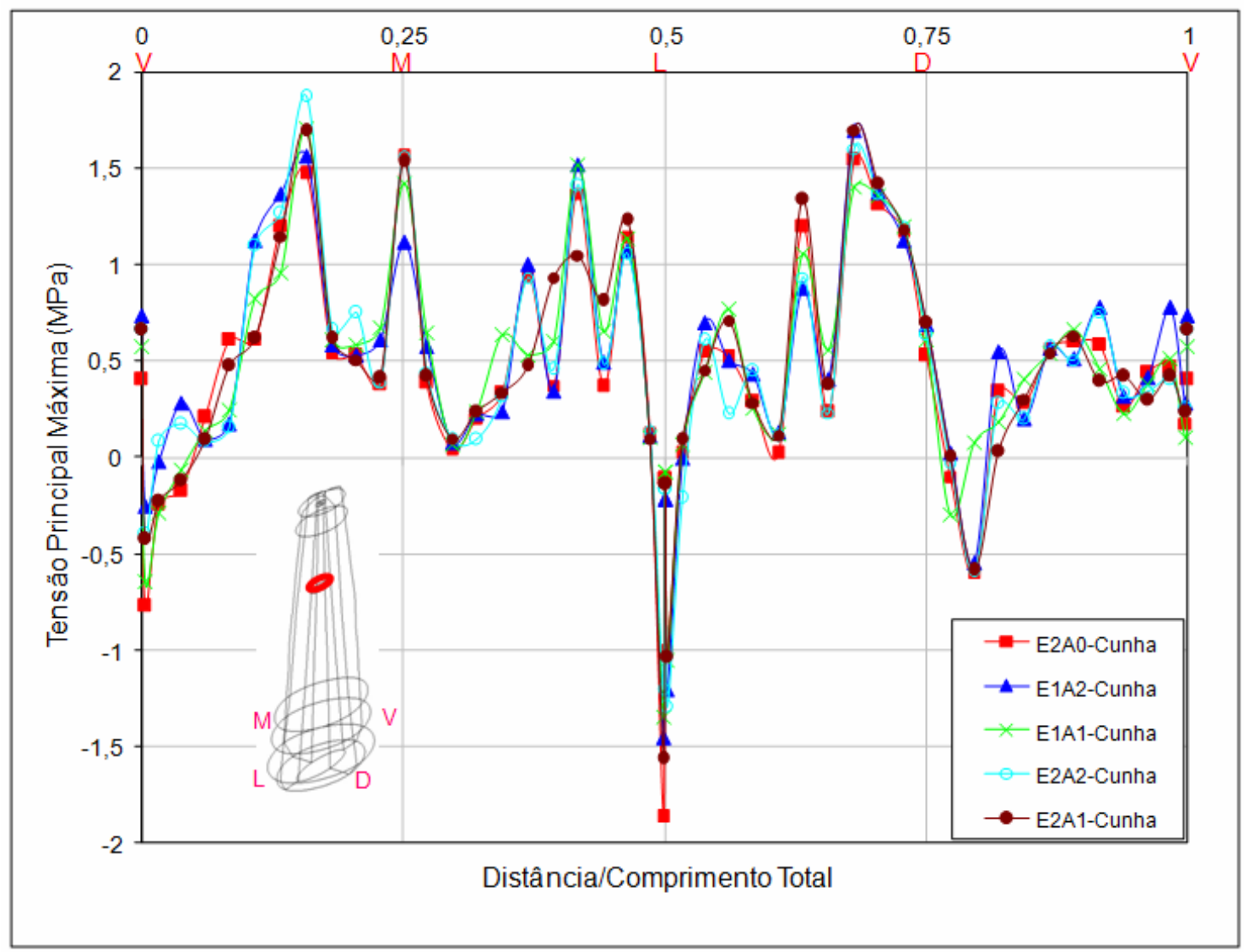

Figura 5.8 - Tensão principal máxima no perímetro apical da dentina radicular sobre o ápice do pino

Como resumo, quando os modelos foram expostos a carregamento longitudinal, não foi possível captar evidências do efeito cunha. O melhor resultado de distribuição de tensões foi obtido pelo E1A2. Para distribuir de melhor modo possível a tensão na dentina radicular sobre o espelho é imprescindível que exista férula. A férula protege a dentina radicular sob o espelho (quanto mais alta, melhor) e a inclinação de $45^{\circ}$ resulta em efeito protetor mais eficiente à dentina sobre 0 espelho. As tensões desenvolvidas ficaram muito aquém das necessárias para a ocorrência de ruptura da dentina radicular, e abaixo da resistência coesiva do 
cimento, o que permitiria afirmar que o carregamento longitudinal não é nocivo à integridade do dente restaurado.

\subsection{Efeito alavanca vestibular- Carregamento $45^{\circ}$ na cúspide vestibular}

As Figuras 5.9, 5.10 e 5.11 apresentam as tensões principais máximas. Na Figura 5.9, uma vista em perspectiva de todas as estruturas; na 5.10 uma vista proximal do osso cortical e lâmina dura; na 5.11, em perspectiva da dentina. $\mathrm{Na}$ Figura 5.12 são apresentados os vetores de tensão compressiva e trativa nos nós de uma linha que percorre a superfície interna e externa da dentina radicular na intersecção com um plano de corte vestíbulo-lingual e outro plano mésio-distal.

Nas Figuras 5.9 e 5.10 os três modelos responderam igualmente, exceto na dentina, como seria de esperar, o que pode ser interpretado como indicador de que todas as condições de contorno dos modelos foram corretamente escolhidas. As diferenças ficaram apenas na Figura 5.11: nos três casos a raiz está sendo dobrada e aparece compressão na vestibular, concentrada na região de contato com a cortical óssea, que atua como fulcro. A tração se concentra e atinge o ponto máximo no lado oposto, palatino, mas, inesperadamente, apresenta uma extensão maior no modelo com férula, com máximas de 104, 110 e $109 \mathrm{MPa}$ respectivamente para o hígido, sem férula e com férula. A Figura 5.12 mostra que os vetores são tangencias na paralelos ao longo eixo, na aresta lingual. O valor de pico é compatível com a ocorrência da fratura. Se a fratura se iniciar nesse local, poderá seguir um plano perpendicular ao vetor de tração e se propagar tendendo a verticalizar, que sugere uma fratura radicular vertical que passaria exatamente no limite da crista óssea. 
Na Figura 5.9 pode ser observado que tanto no modelo E1A2 como no modelo sem férula concentram-se tensões trativas na linha de cimento, o que já era esperado, por ser o cimento um material de menor módulo entre dois materiais de maior rigidez (dentina-metal ou metal-metal) que apresentam compressão. Nota-se que o modelo E1A2 apresenta tensões trativas nas duas linhas de cimento expostas. 


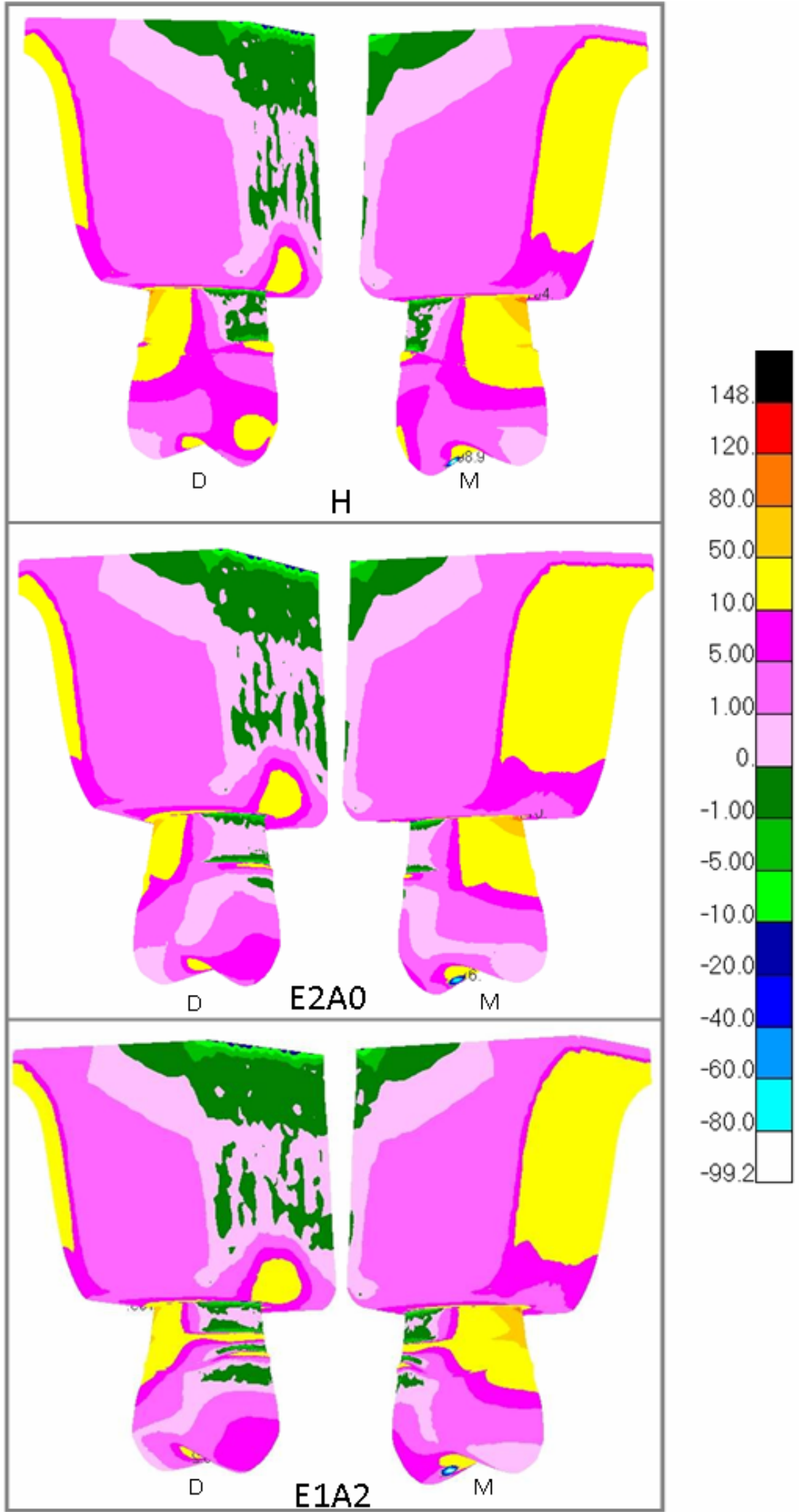

Figura 5.9 - Vista em perspectiva de todas as estruturas. Tensões principais máximas em todos os modelos carregados $45^{\circ}$ na cúspide vestibular 


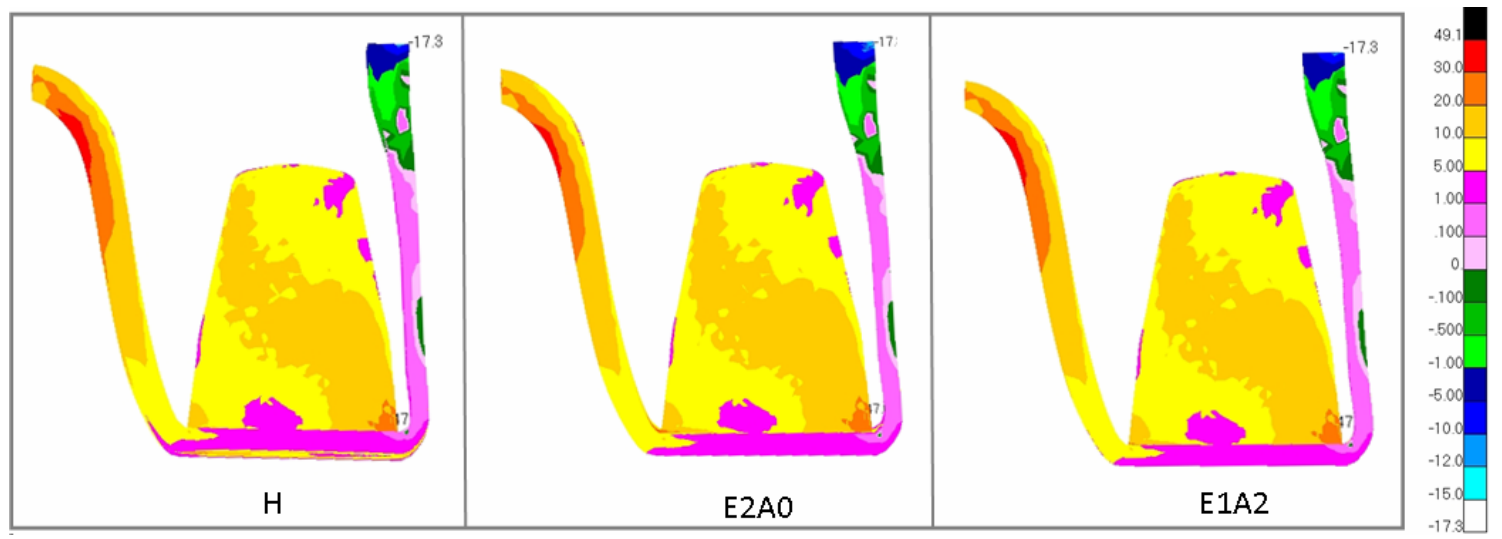

Figura 5.10 - Vista proximal do osso. Tensões principais máximas em todos os modelos carregados $45^{\circ}$ na cúspide vestibular

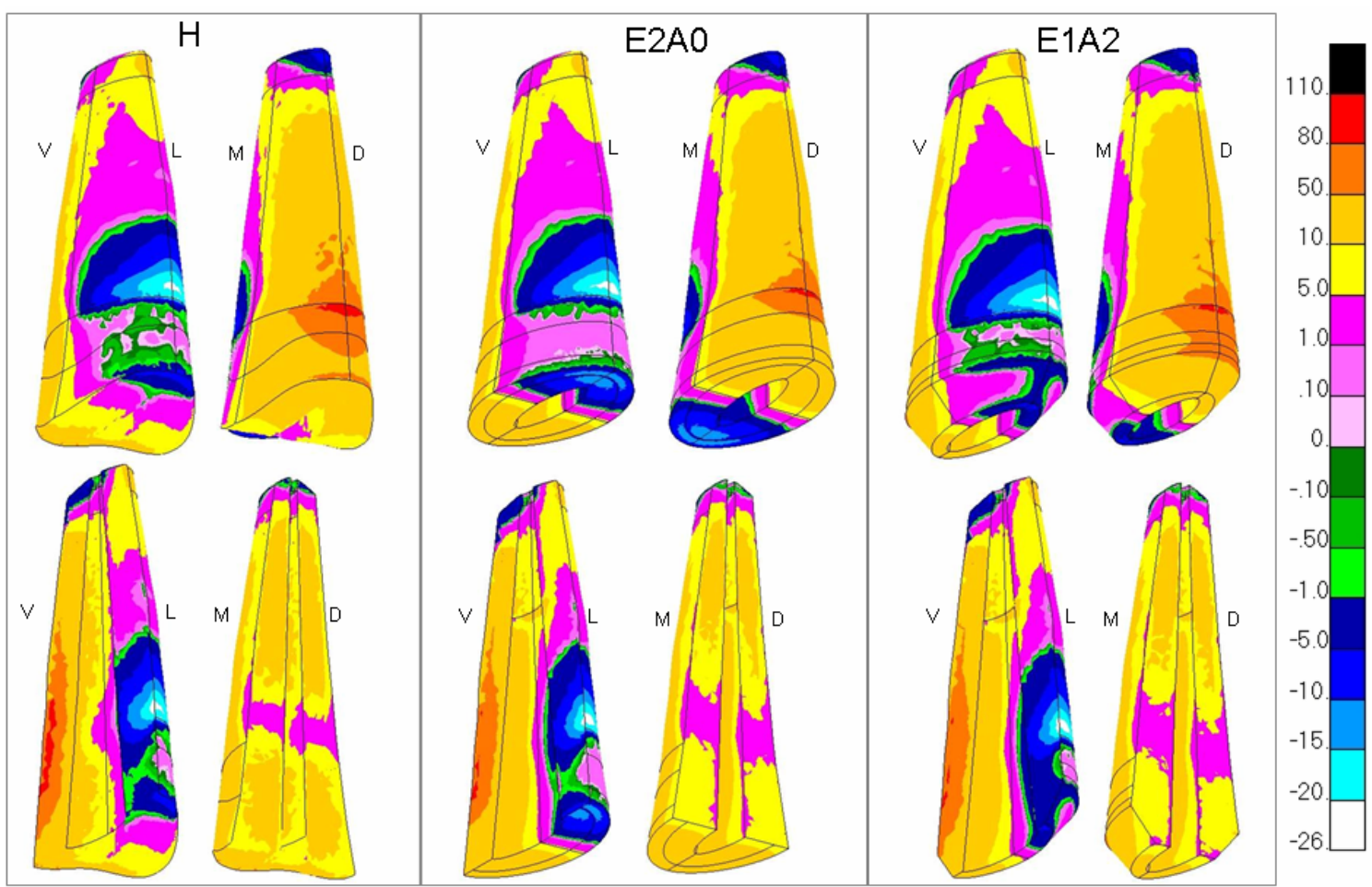

Figura 5.11 - Vista em perspectiva da dentina. Tensões principais máximas em todos os modelos carregados $45^{\circ}$ na cúspide vestibular

Fraturas radiculares verticais aparecem como resultado de tensões geradas de no interior do canal radicular (LERTCHIRAKAM; PALAMARA; MESSER, 2003). Os modelos mostraram tração concentrada no ápice do pino, embora de menor magnitude que na altura da crista óssea. 
Em todos os modelos, as tensões internas do canal no corte mésio-distal apresentaram tensões trativas (com exceção da região próxima ao ápice do pino) e próximo a crista marginal óssea apresentam mudança de orientação dos tensores devido à rotação dos mesmos, que parece relacionada com a presença de osso cortical. Ou seja: a região da fratura depende não apenas do pino e férula, mas também da localização da região de inserção do dente no alvéolo.

Chama a atenção que as diferenças entre os três modelos sejam relativamente pequenas, o que não justificaria o fato de não se encontrar clinicamente a fratura de dentes hígidos ao mesmo tempo em que são relativamente freqüentes as fraturas entre os restaurados com pinos metálicos. Essa semelhança de resposta poderia ser atribuída ao fato dos modelos terem simulado adesão perfeita. A adesão perfeita pode ir se perdendo com o passar do tempo, o que explicaria que os fracassos não costumem ocorrer em peças recentemente cimentadas. Por outro lado, os modelos mostraram elevada concentração de tensões de tração em mais da metade do corpo do cimento, bem acima da necessária para a sua fratura coesiva (ver Figura 5.13 e Tabela 4.3). Isto concorda com a observação de que a utilização de cimentos que tenham baixa resistência pode levar a falhas através do afrouxamento do pino e posterior fratura da raiz (COHEN; MUSIKANT; DEUTSCH, 1993). 


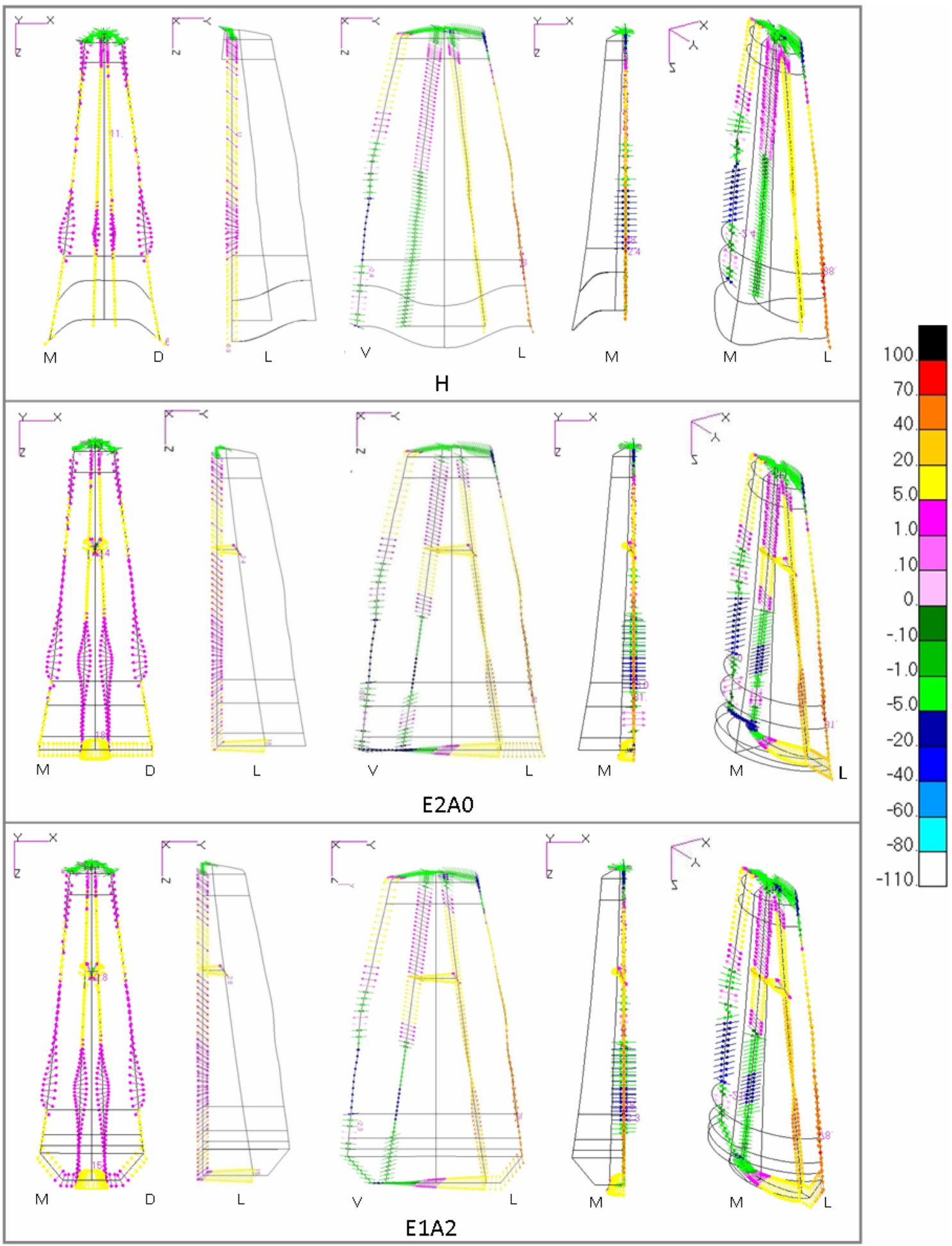

Figura 5.12 - Vetores resultantes das tensões principais máximas na superfície interna e externa da dentina radicular, corte mésio-distal e vestíbulo-lingual, respectivamente 
Sob carregamento posicionado na cúspide vestibular, que gera efeito alavanca, as tensões trativas sobre a férula atingiram $40 \mathrm{MPa}$, que ultrapassa o valor de resistência a tração (8,3 MPa) e associada à orientação destas tensões (Figura 5.12) sugere grande tendência a descolar ou romper a camada de cimento na região.
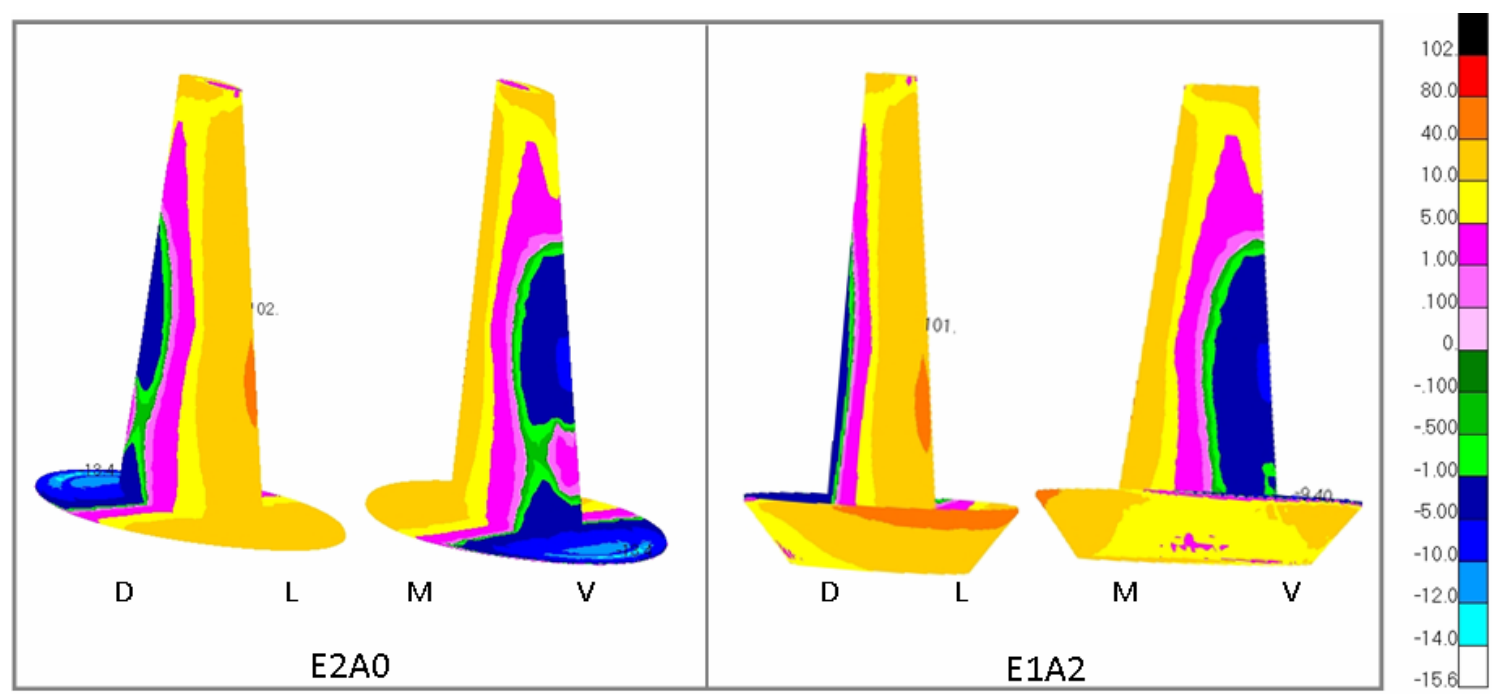

Figura 5.13 - Vista em perspectiva do cimento entre o retentor e a dentina. Tensões principais máximas em todos os modelos carregados $45^{\circ}$ na cúspide vestibular

Como resumo, quando os modelos foram expostos a carregamento oblíquo $\left(45^{\circ}\right)$ na cúspide vestibular, as tensões de tração se concentram e atinge o ponto máximo na face lingual, mas, inesperadamente, apresenta uma extensão maior no modelo com férula, com máximas compatível com a ocorrência da fratura. Se a fratura se iniciar nesse local, poderá seguir um plano perpendicular ao vetor de tração e se propagar tendendo a verticalizar, que sugere uma fratura radicular vertical que passaria exatamente no limite da crista óssea.

A férula cervical ajuda a manter a integridade do selamento do cimento sob carregamento com resultante paralela ao longo eixo do dente, pois sob carregamento posicionado na cúspide vestibular, que gera efeito alavanca, as 
tensões trativas no cimento sobre a férula ultrapassam o valor de sua resistência a tração e associada à orientação destas tensões sugere grande tendência a descolar ou romper a camada de cimento na região.

\subsection{Efeito alavanca proximal - Carregamento $0^{\circ}$ na crista marginal mesial}

As Figuras 5.14, 5.15 e 5.16 apresentam as tensões principais máximas. Na Figura 5.14 uma vista em perspectiva de todas as estruturas; na 5.15 uma vista proximal do osso cortical e lâmina dura; na 5.16, em perspectiva da dentina. $\mathrm{Na}$ Figura 5.17 são apresentados os vetores de tensão compressiva e trativa nos nós de uma linha que percorre a superfície interna e externa da dentina radicular na intersecção com um plano de corte vestíbulo-lingual e outro plano mésio-distal.

A Figura 5.16 mostra que o modelo com férula (E1A2) apresenta maior região de concentração de tensões trativas, no lado oposto ao da aplicação da carga. Assim, não pode ser confirmado o efeito protetor da férula sob este tipo de carregamento.

Tanto o modelo E1A2 como o modelo sem férula apresentaram tensões trativas na linha de cimento, o que seria explicável por se encontrar entre dois materiais de maior rigidez que sofrem compressão (Figura 5.14). 


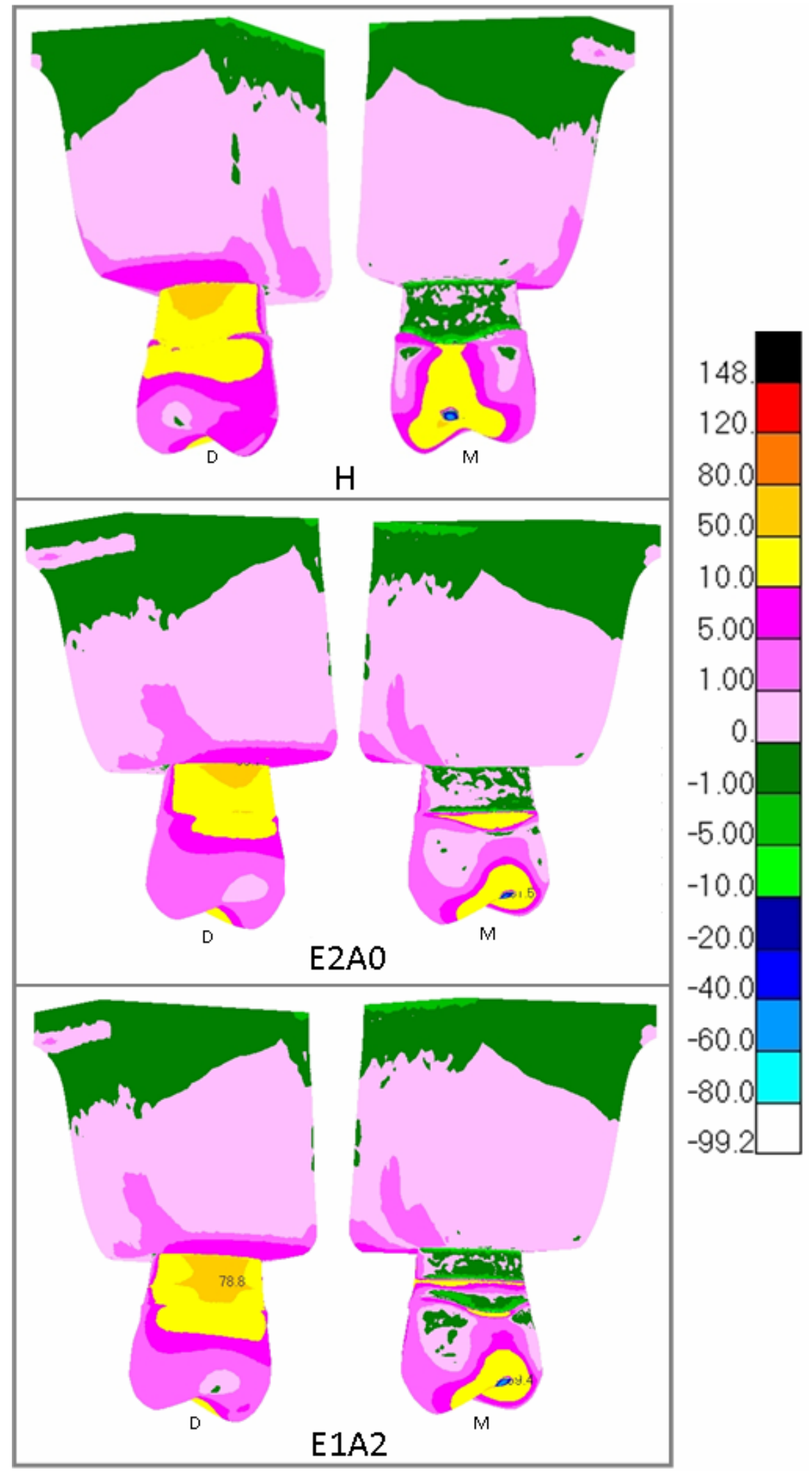

Figura 5.14 - Vista em perspectiva de todas as estruturas. Tensões principais máximas em todos os modelos carregados $0^{\circ}$ na crista marginal mesial 


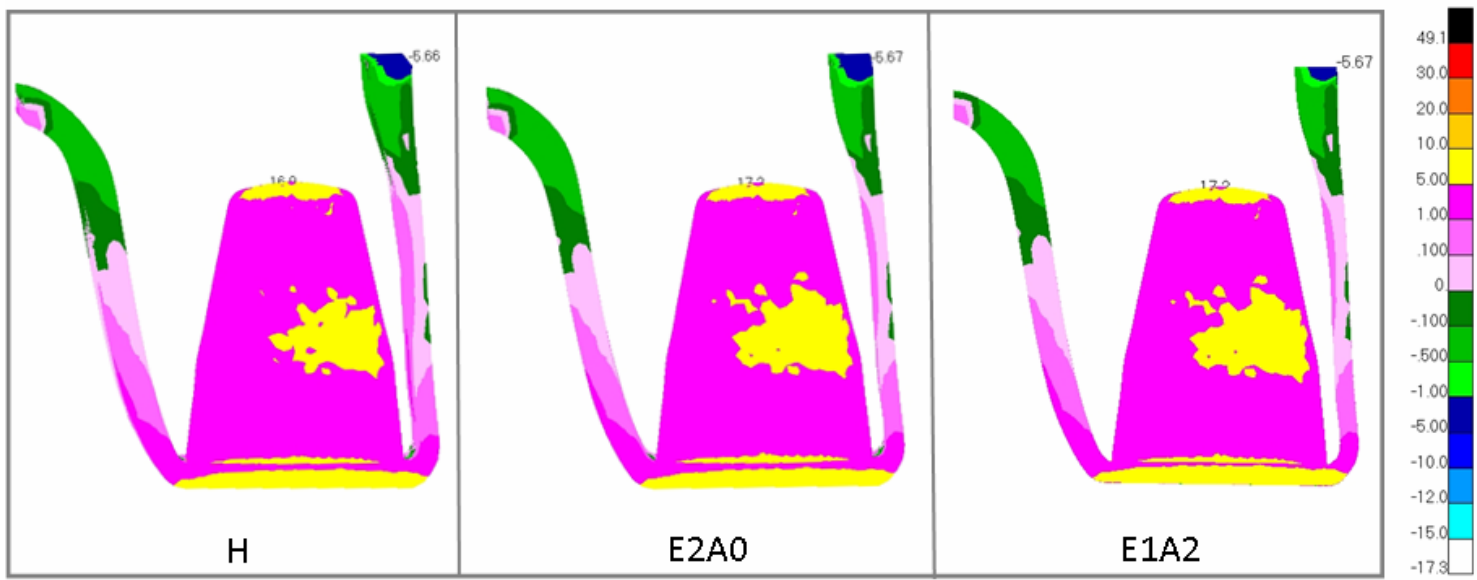

Figura 5.15 - Vista proximal do osso. Tensões principais máximas em todos os modelos carregados $0^{\circ}$ na crista marginal mesial

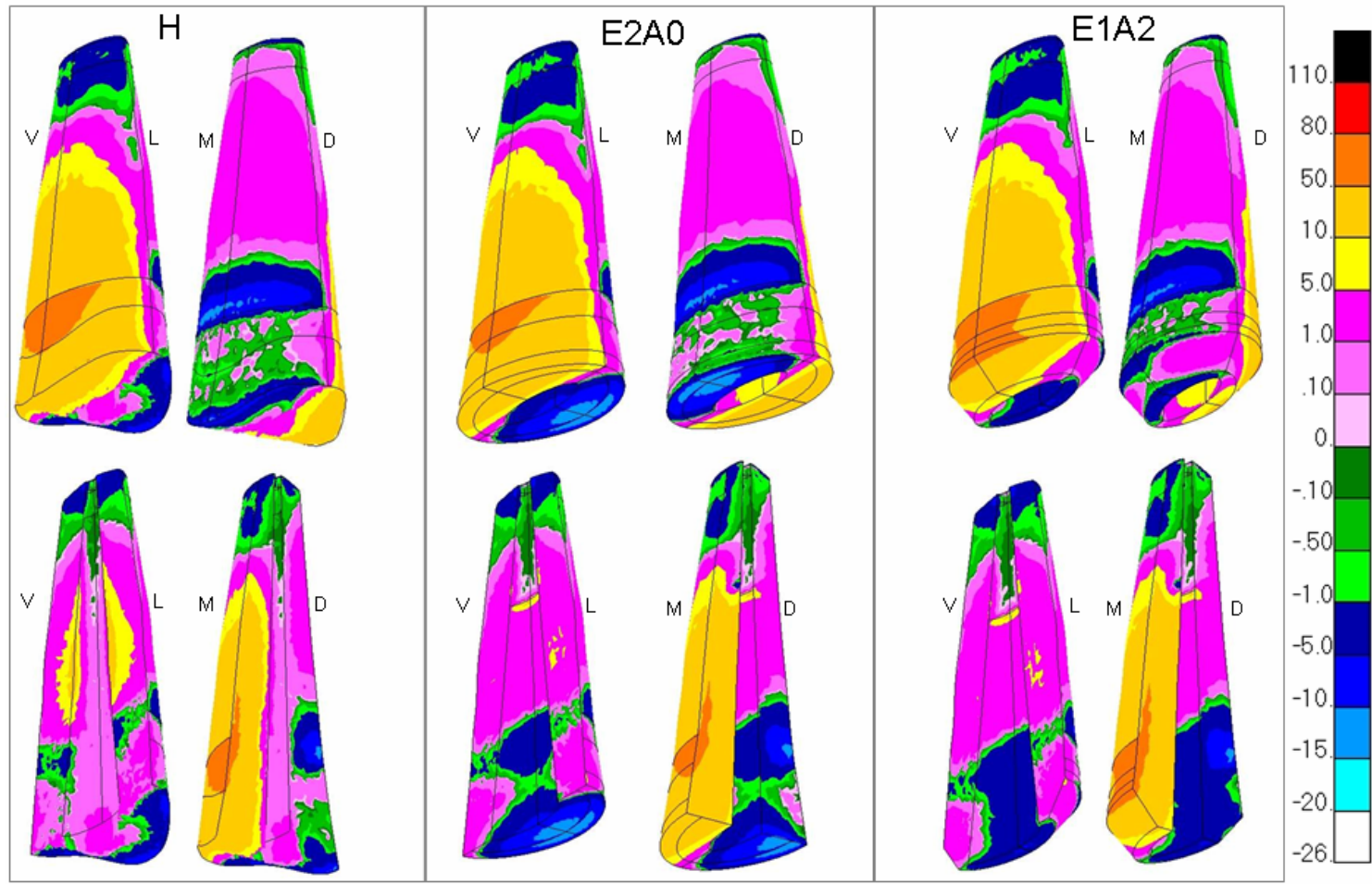

Figura 5.16 - Vista em perspectiva da dentina. Tensões principais máximas em todos os modelos carregados $0^{\circ}$ na crista marginal mesial

A Figura 5.17 mostra semelhança de orientação das tensões em todos os casos. Os picos de tensão trativas na aresta distal são também muito parecidos (68, 68 e $67 \mathrm{MPa}$ ), menores que no caso de alavanca vestibular. Ou seja: o dente 
restaurado com pino apresentaria uma tendência à ruptura semelhante à do hígido, o que não é suportado pelas observações clínicas. A explicação para esta discrepância poderia estar novamente no fato de que o cimento apresentou tensões muito maiores que as necessárias para a sua fratura coesiva. Depois de romper o cimento a distribuição de tensões seria diferente e poderia propiciar a fratura da raiz. A Figura 5.18 mostra que o cimento sofre maior pico de tensão no caso com férula (79 MPa) que no caso sem férula (54 MPa). 


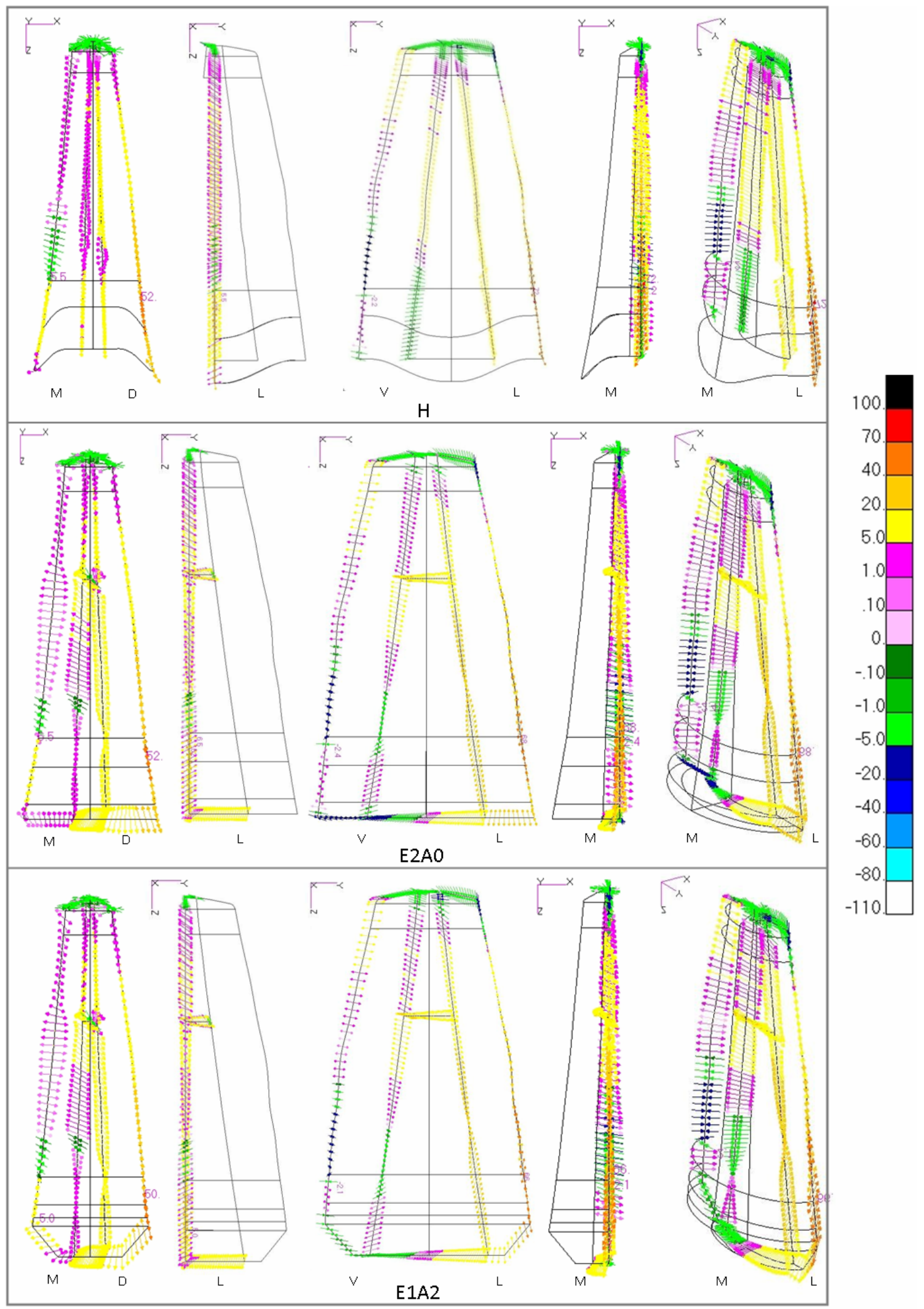

Figura 5.17 - Vetores resultantes das tensões principais máximas na superfície interna e externa da dentina radicular, corte mésio-distal e vestíbulo-lingual, respectivamente 


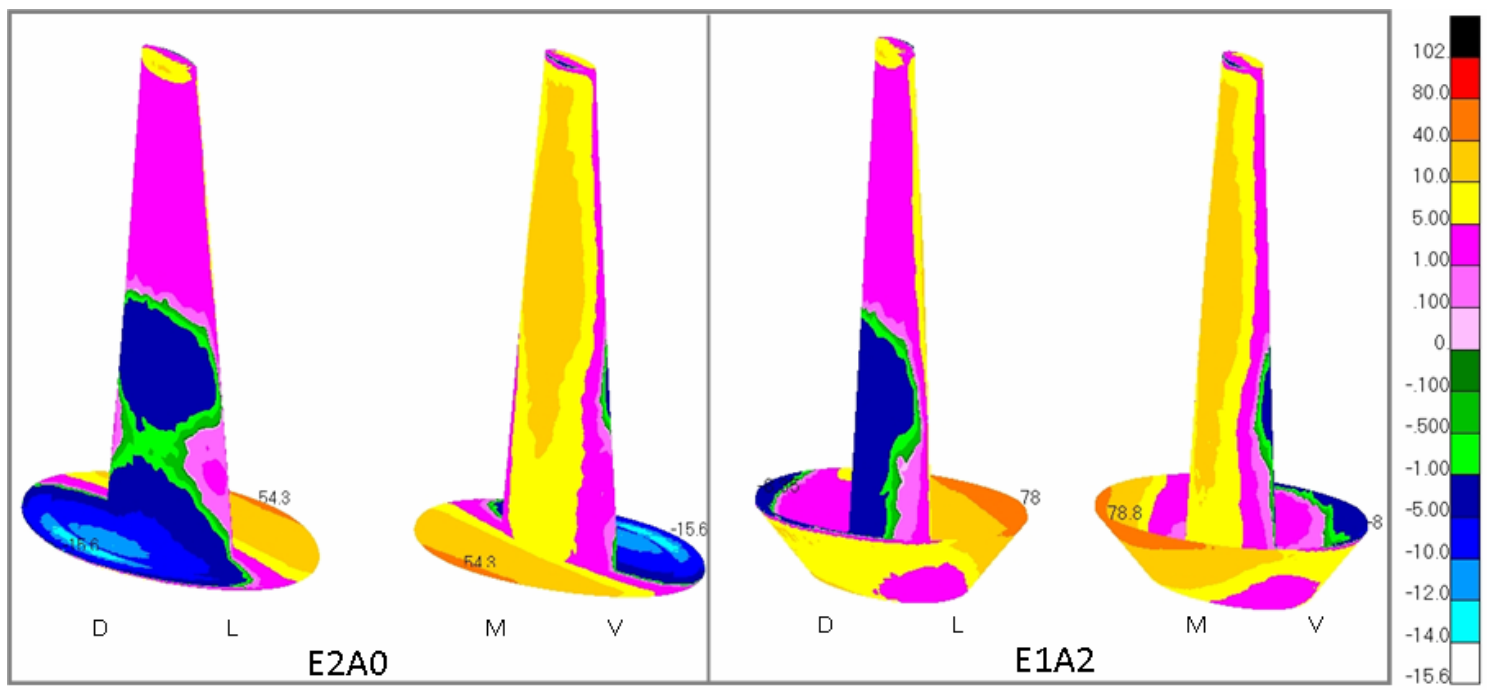

Figura 5.18 - Vista em perspectiva do cimento entre o retentor e a dentina. Tensões principais máximas em todos os modelos carregados $0^{\circ}$ na crista marginal mesial

\subsection{Efeito Torção - Carregamento $45^{\circ}$ na crista marginal mesial}

As Figuras 5.19, 5.20 e 5.21 apresentam as tensões principais máximas. Na Figura 5.19 uma vista em perspectiva de todas as estruturas; na 5.20 uma vista proximal do osso cortical e lâmina dura; na 5.21, em perspectiva da dentina. Na Figura 5.22 são apresentados os vetores de tensão compressiva e trativa nos nós de uma linha que percorre a superfície interna e externa da dentina radicular na intersecção com um plano de corte vestíbulo-lingual e outro plano mésio-distal.

A Figura 5.19 já mostra para o modelo com férula uma maior extensão da região cervical submetida à tração, o que fica mais evidente na figura 5.21. A Figura 5.22 evidencia novamente que o cimento fica submetido à tensão superior a sua resistência coesiva e que a concentração é mais grave no caso com férula. Quando o cimento ao redor da porção mais coronária se deteriora, o fulcro migra 
apicalmente, o que aumenta progressivamente o braço de alavanca (COHEN; MUSICANT; DEUTSCH, 1993).

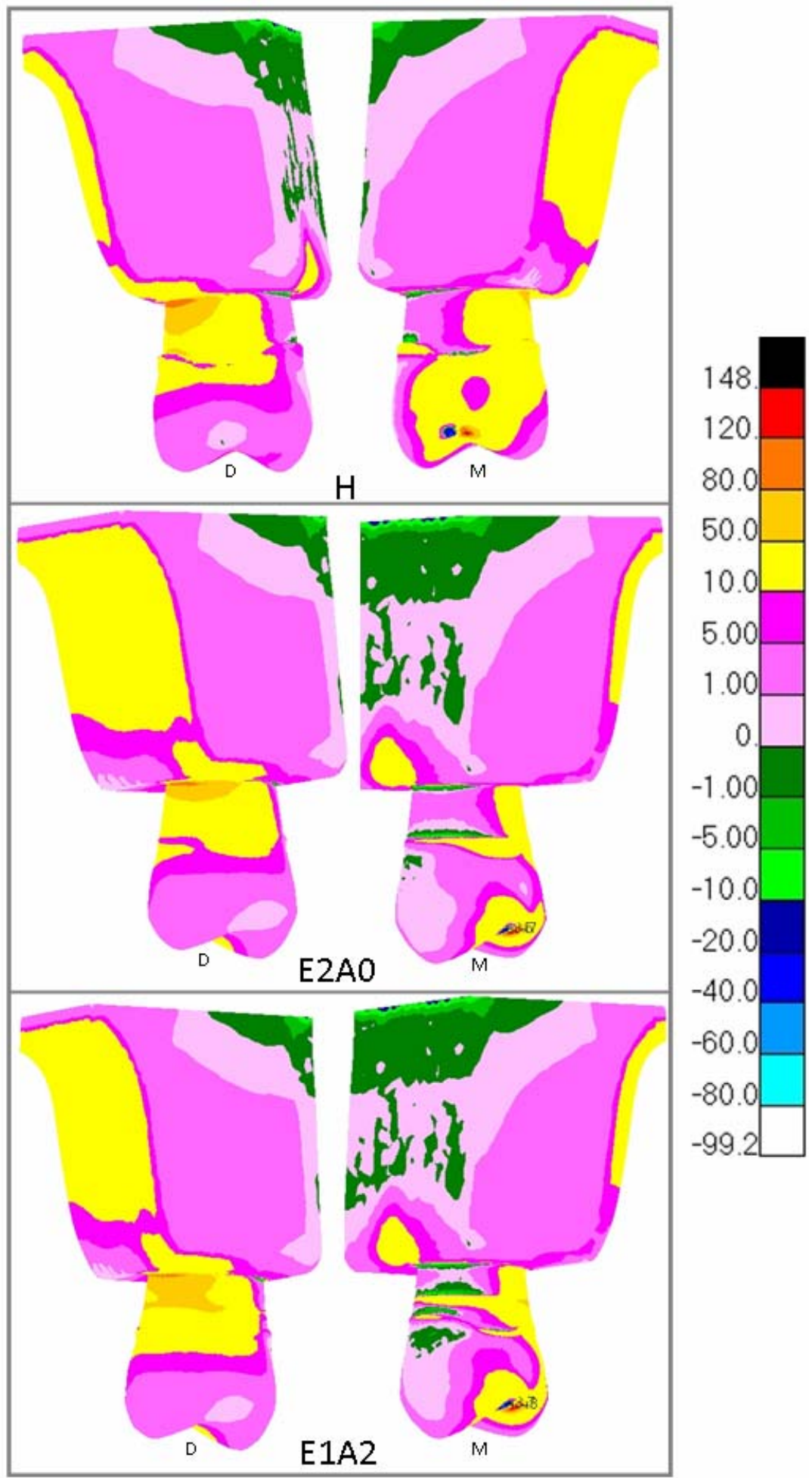

Figura 5.19 - Vista em perspectiva de todas as estruturas. Tensões principais máximas em todos os modelos carregados $45^{\circ}$ na crista marginal mesial 

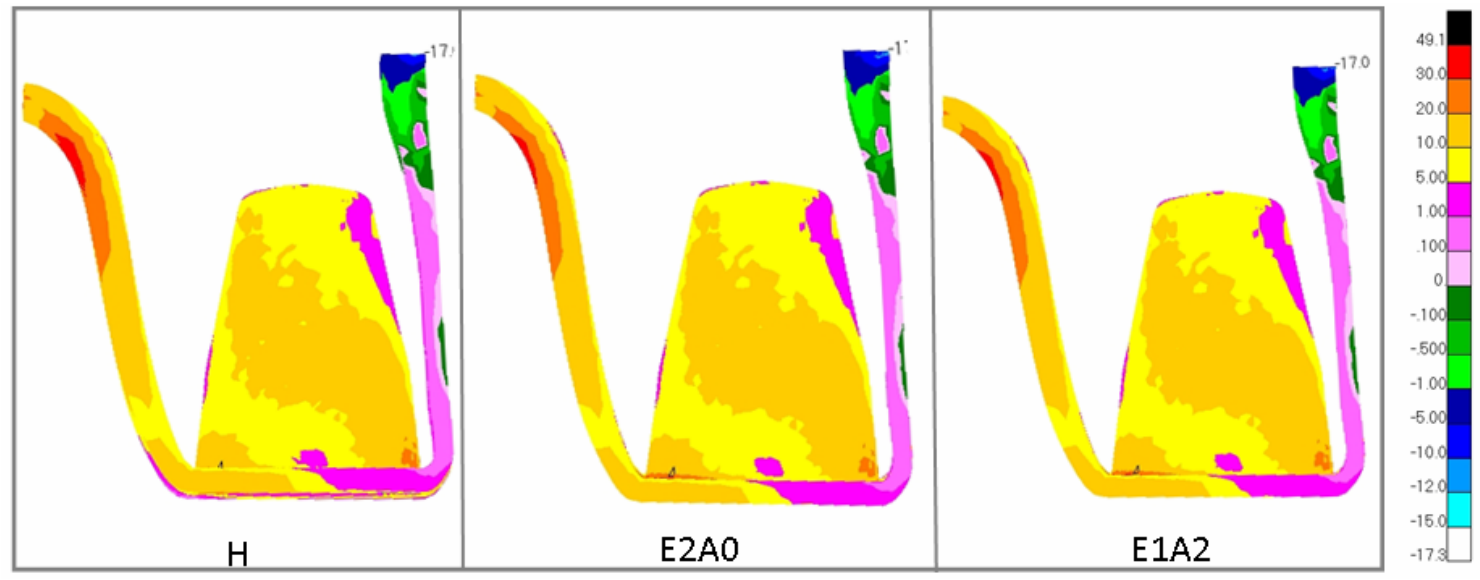

Figura 5.20 - Vista proximal do osso. Tensões principais máximas em todos os modelos carregados $45^{\circ}$ na crista marginal mesial

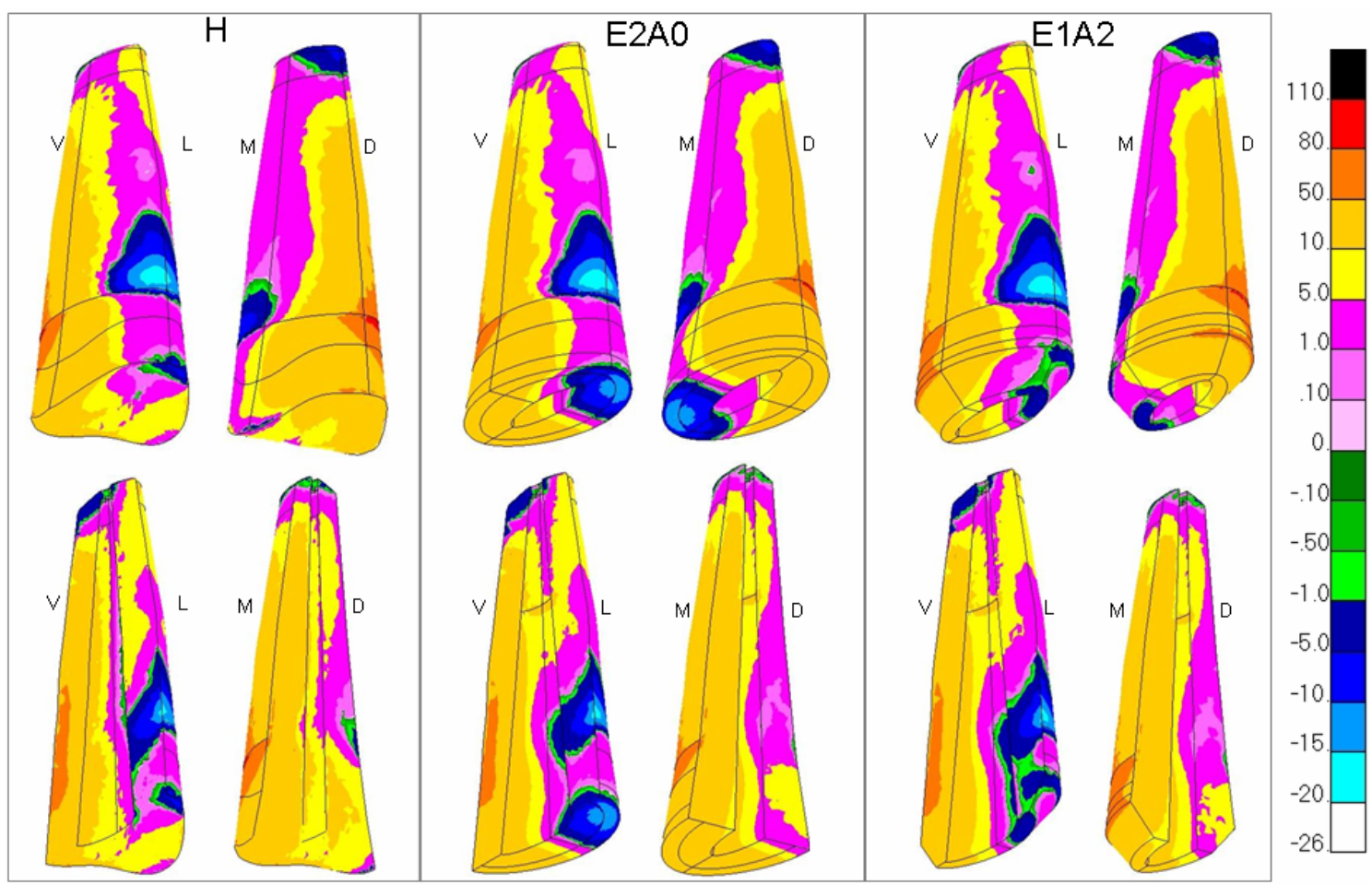

Figura 5.21 - Vista em perspectiva da dentina. Tensões principais máximas em todos os modelos carregados $45^{\circ}$ na crista marginal mesial 


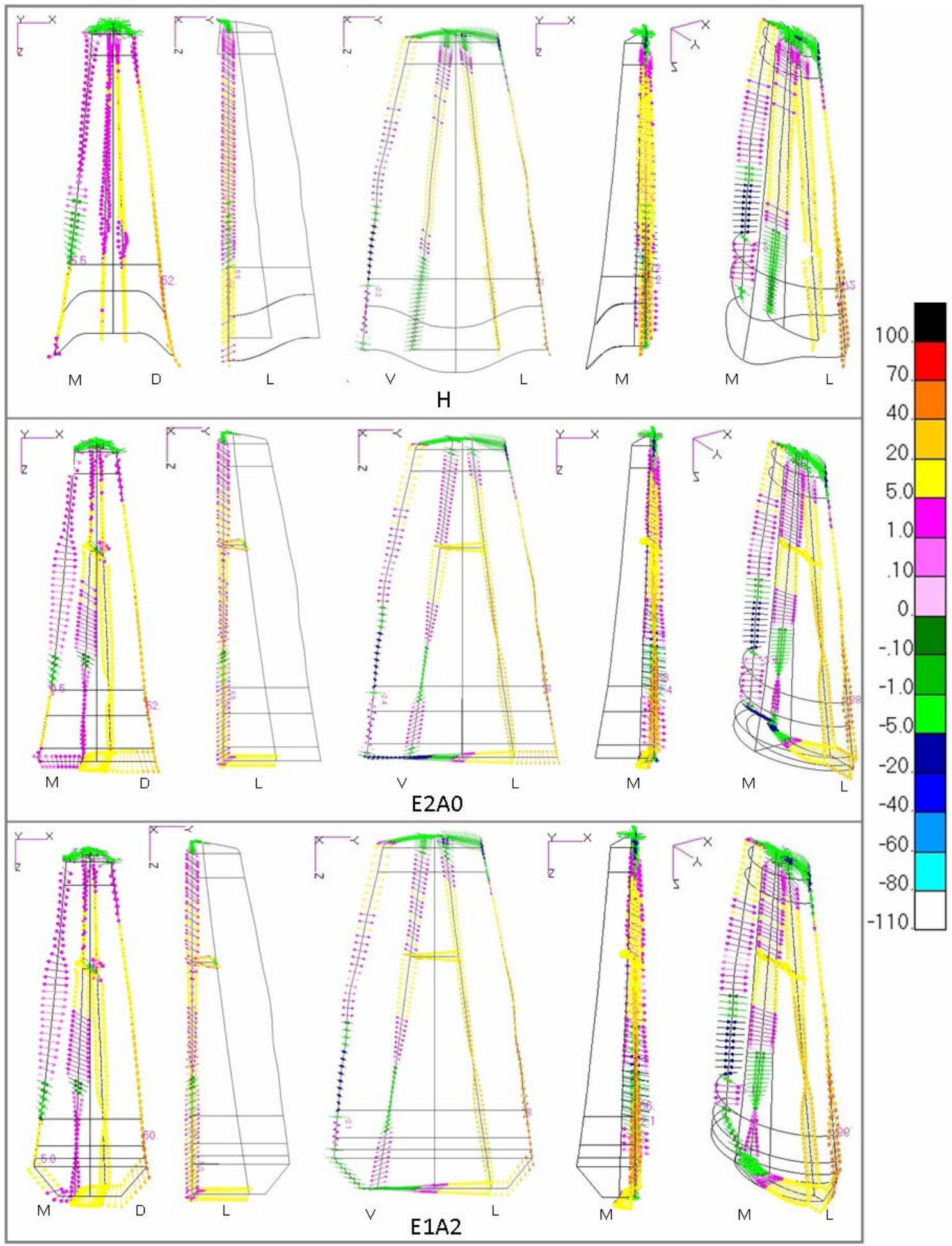

Figura 5.22 - Vetores resultantes das tensões principais máximas na superfície interna e externa da dentina radicular, corte mésio-distal e vestíbulo-lingual, respectivamente 


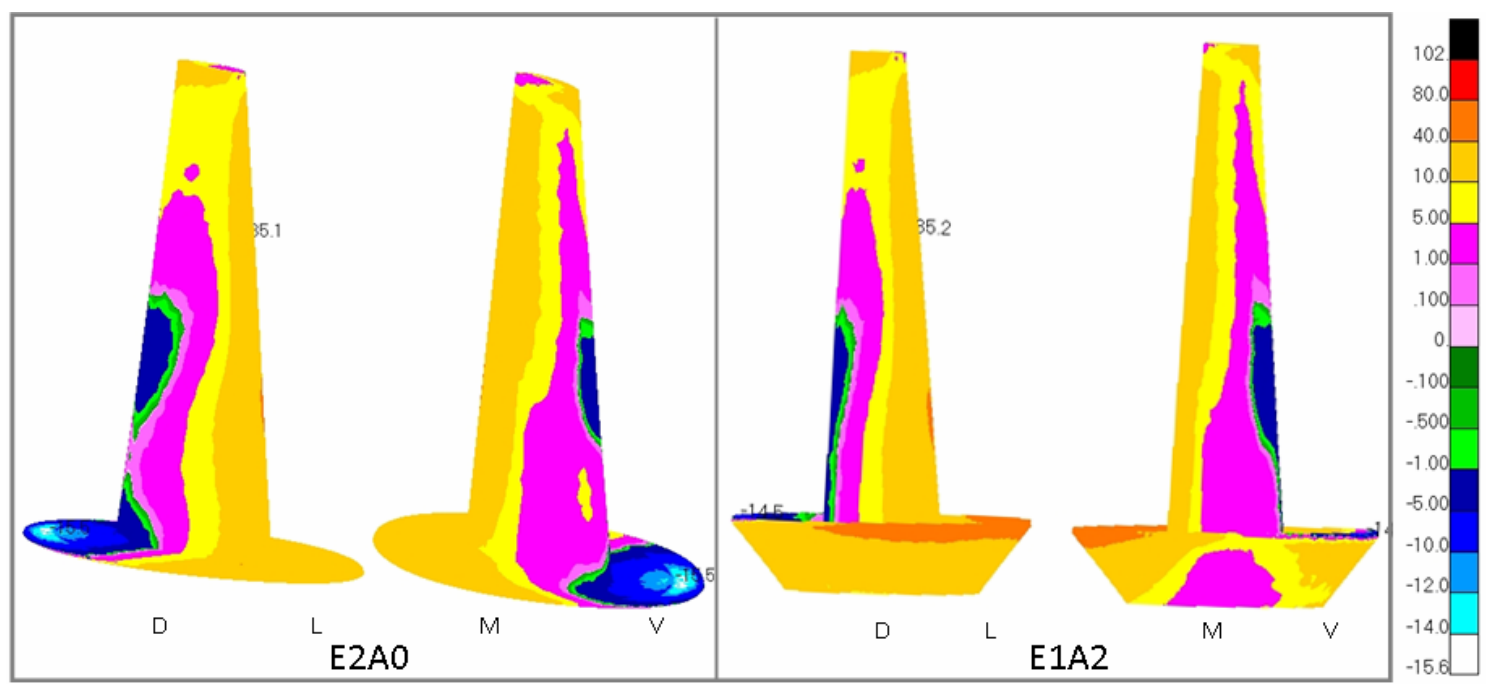

Figura 5.23 - Vista em perspectiva do cimento entre o retentor e a dentina. Tensões principais máximas em todos os modelos carregados $45^{\circ}$ na crista marginal mesial

\subsection{Gráficos de tensões}

Nas Figuras 5.24 a 5.32 são apresentadas as tensões principais máximas numa aresta, indicada no desenho correspondente de cada gráfico, da superfície da dentina radicular, em função da posição relativa do nó sob todos os carregamentos.

Na Figura 5.24 é apresentada a aresta externa da face lingual. Observa-se que os modelos que geram cunha ou os que geram alavanca proximal apresentam, na aresta lingual, tensões muito baixas, todas da mesma ordem de grandeza. Já os modelos que geram alavanca vestibular e torque apresentam altas tensões trativas nesta aresta. O modelo E1A2 é o que parece apresentar menores tensões no gráfico, mas o gráfico não é conclusivo porque, ao mudar o ponto de aplicação de carga, muda o local de máxima tensão. Na realidade, este tipo de comparação deve ser feito nas figuras que mostram a distribuição de tensão na dentina. 


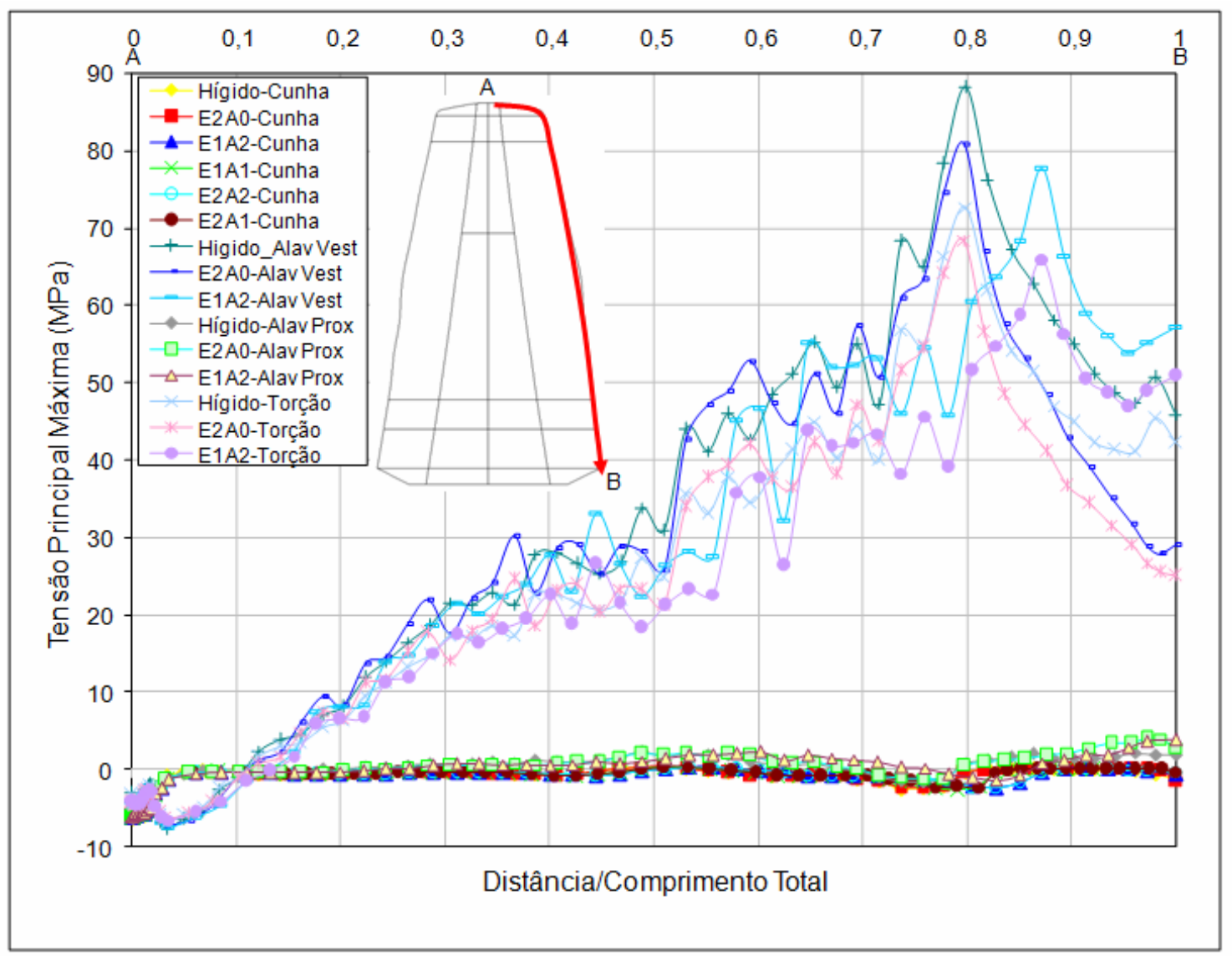

Figura 5.24 - Tensão principal máxima apresentada na aresta da dentina radicular, na face lingual, em função da posição relativa do nó, a partir do ápice para a região cervical, sob todos os carregamentos

Na Figura 5.25 é apresentada a aresta externa da face vestibular. Observa-se que os modelos que geram cunha e alavanca proximal têm a mesma ordem de grandeza de tensões atuantes na aresta vestibular, com inflexão no comportamento (tração para compressão) do sentido ápice-cervical. Nos modelos que geram alavanca proximal, as tensões trativas próximo ao ápice são próximas ao do efeito cunha, entretanto, próximo a cervical, as tesões de tração aumentam até $5 \mathrm{MPa}$ (mesmo com esse valor, ainda ficou muito longe da tensão de ruptura da dentina). 


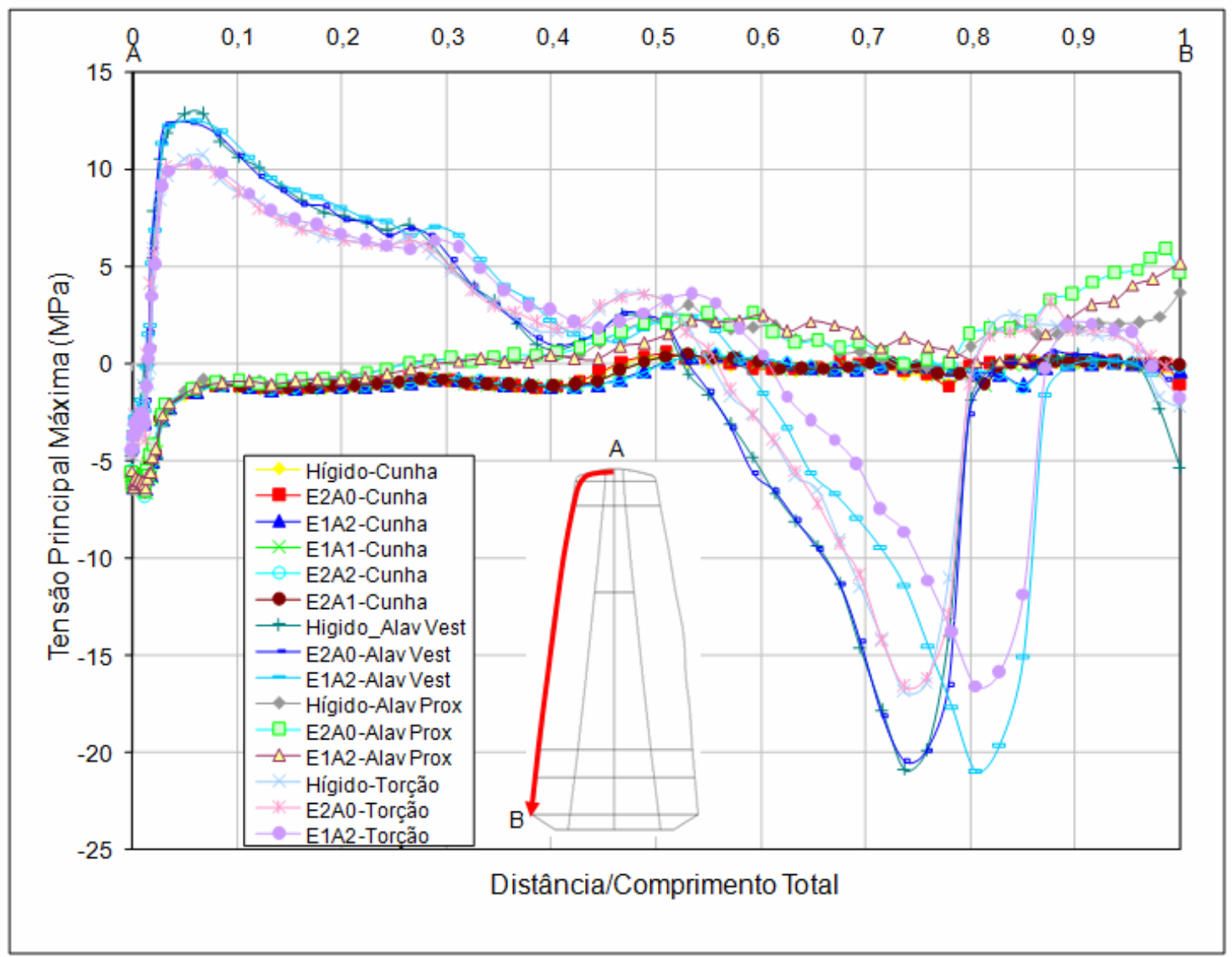

Figura 5.25 - Tensão principal máxima apresentada na aresta da dentina radicular, na face vestibular, em função da posição relativa do nó, a partir do ápice para a região cervical, sob todos os carregamentos

Na Figura 5.26 é apresentada a aresta externa da face distal. Observam-se menores tensões nos modelos de cunha, seguidos melos modelos com alavanca vestibular, modelos de torção e alcançando o máximo com a alavanca proximal. Nos modelos de efeito alavanca proximal e torque geram-se pico de tensão nos mesmos nós de mesmos modelos; a intensidade menor para o torque poderia ser devida à menor componente longitudinal da carga nesse caso. 


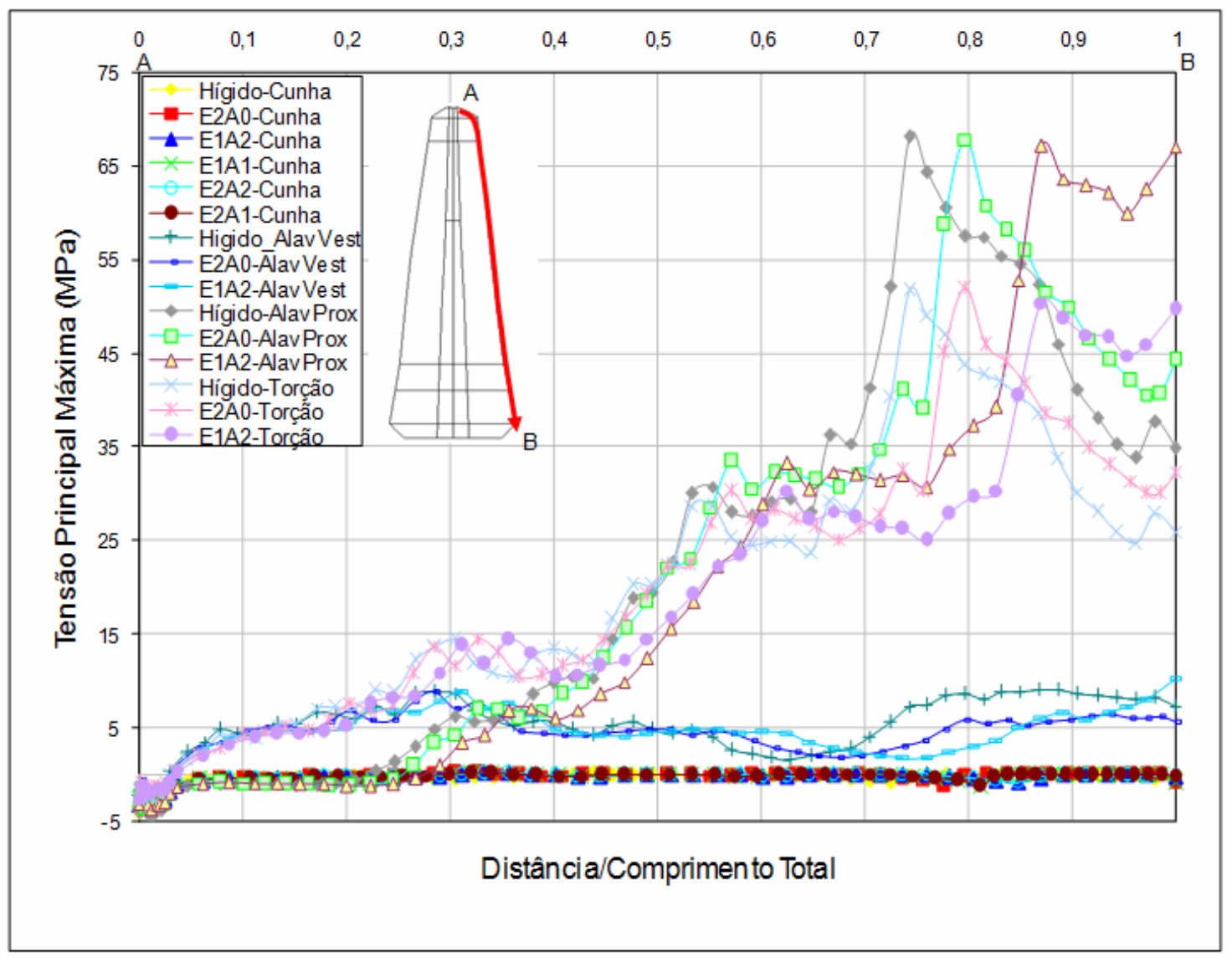

Figura 5.26 - Tensão principal máxima apresentada na aresta da dentina radicular, na face distal, em função da posição relativa do nó, a partir do ápice para a região cervical, sob todos os carregamentos

Na Figura 5.27 é apresentada a aresta externa da face mesial. Observam-se menores tensões nos modelos de cunha. A inversão de tração para compressão ocorre, como corresponde, de modo evidente nos modelos de alavanca proximal, e de modo mais suave nos modelos de torção. A ordem de grandeza de todas as tensões está muito abaixo da necessária para provocar fratura. 


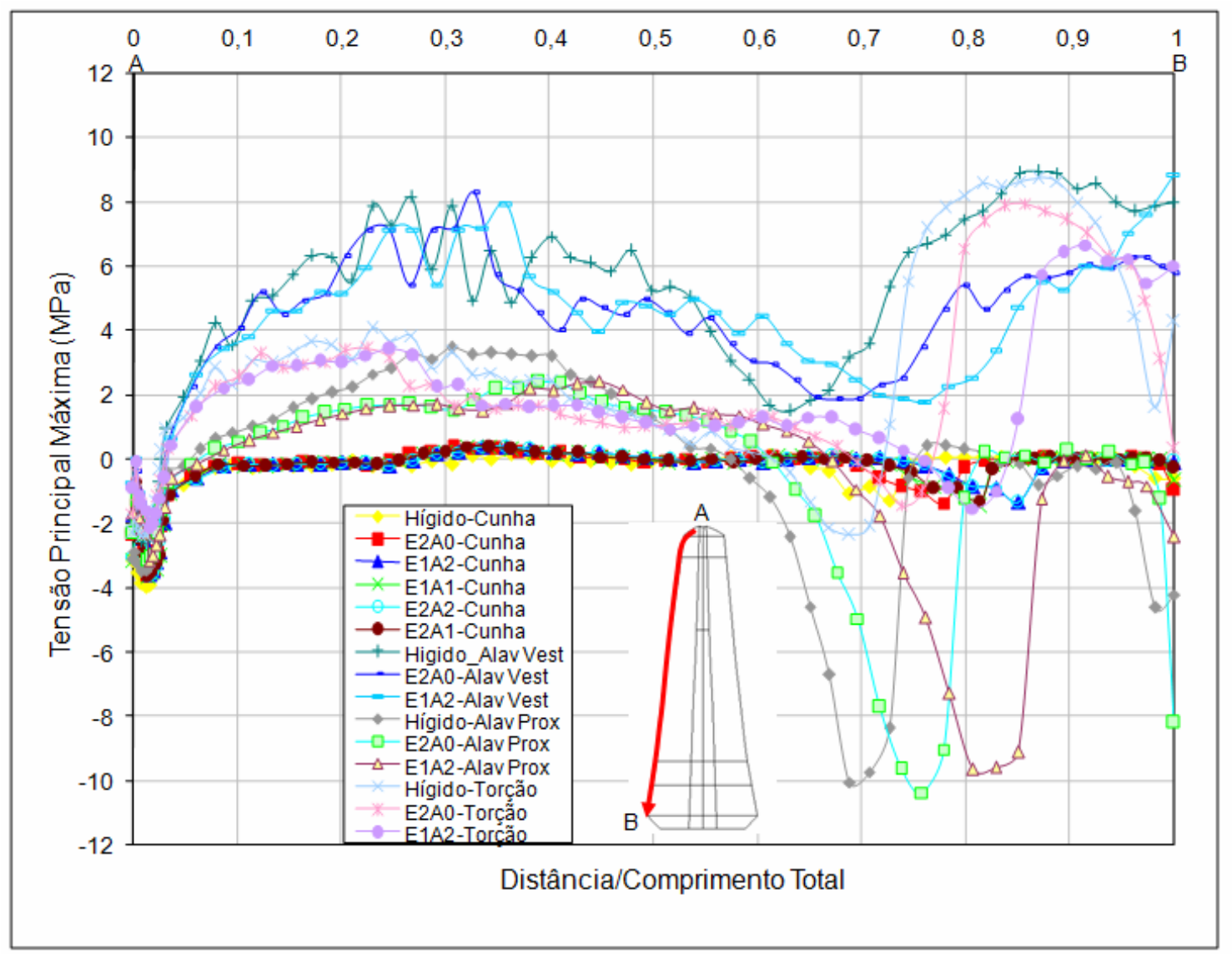

Figura 5.27 - Tensão principal máxima apresentada na aresta da dentina radicular, na face mesial, em função da posição relativa do nó, a partir do ápice para a região cervical, sob todos os carregamentos

Na Figura 5.28 é apresentada a aresta interna da face lingual. Observam-se menores tensões nos modelos de cunha e tensões trativas de até $45 \mathrm{MPa}$ nos modelos de alavanca vestibular, seguidos pelos modelos que geram torção, mas em ambos tipos de carregamentos, nos modelos de dente hígido as tensões são menores. Parece importante destacar que a ordem de valores é bem inferior aos da Figura 5.24, correspondente à face externa, o que conduz a pensar que a fratura deverá se iniciar na face externa, aparentemente motivada por dobramento do dente como um todo. Descarta-se a possibilidade de fratura motivada pela concentração de tensões na face interna, que poderia ser motivada pelo efeito cunha promovido pelo pino. 
A Figura 5.24 mostra que a maior tensão na aresta externa foi alcançada pelo dente hígido. No entanto, seria pouco provável que o dente hígido tivesse maior tendência à fratura: não é isso que se observa na prática.

Por outro lado a Figura 5.28 mostra que a tensão quase se duplica na aresta interna, para os casos de alavanca vestibular com pino, em relação ao dente hígido. Isto faz pensar que o critério de falha não deve ser simplesmente o valor da máxima principal, mas deve sofrer influência do gradiente de tensões.

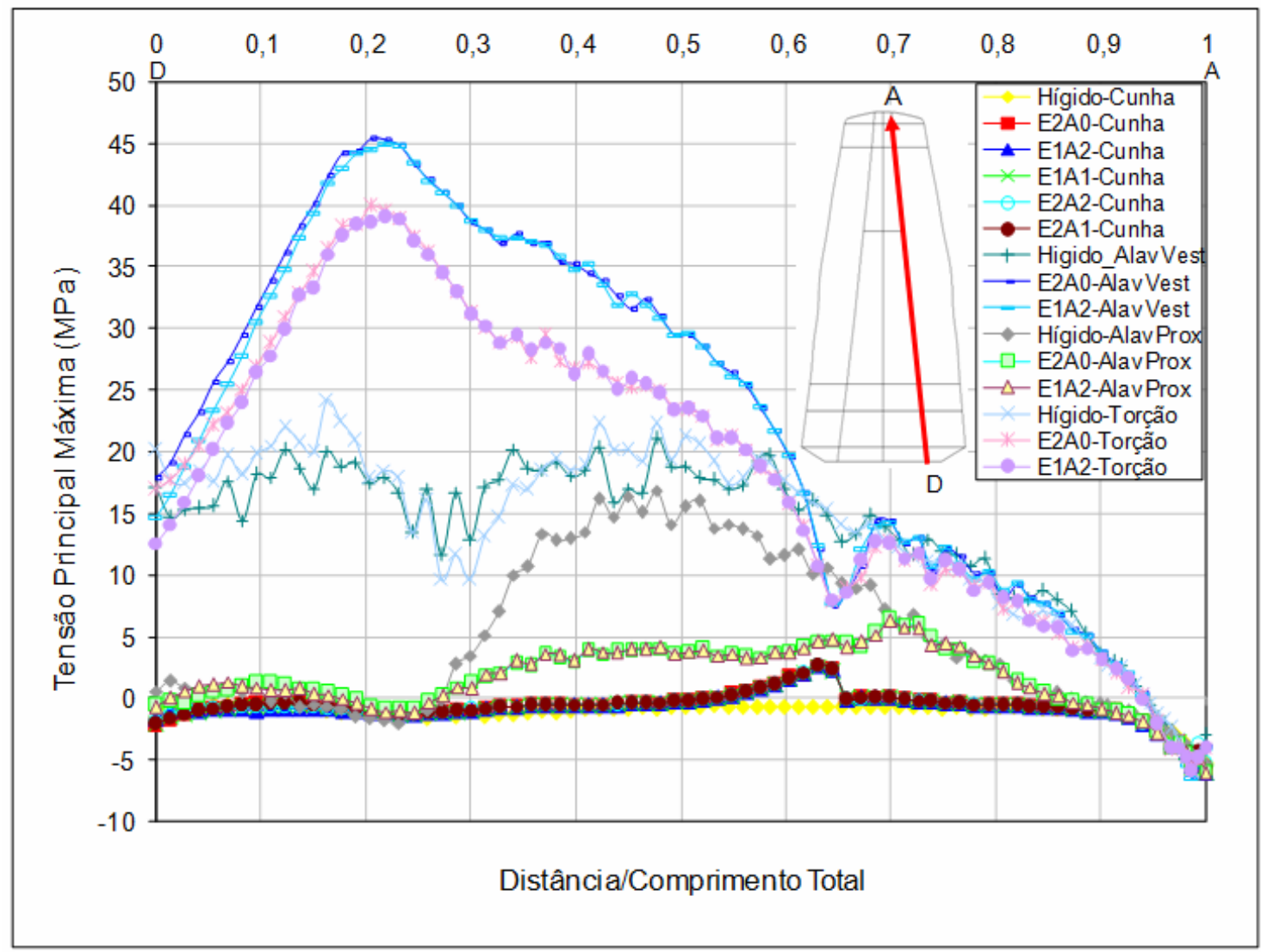

Figura 5.28 - Tensão principal máxima apresentada na aresta da dentina radicular, na face lingual, em função da posição relativa do nó, a partir do ápice para a região cervical, sob todos os carregamentos 
Na Figura 5.29 é apresentada a aresta interna da face vestibular. Observamse tensões trativas de até $27 \mathrm{MPa}$ na região próxima ao ápice do pino nos modelos que geram alavanca vestibular, seguidos pelos modelos que geram torção, mas em ambos tipos de carregamento, as tensões são menores nos modelos de dente hígido. A Figura 5.12 permite verificar que a direção desse pico de tração é radial e, portanto não tende a provocar fratura longitudinal, mas delaminação na dentina e descolamento do ápice do pino. Aliás, apresenta uma direção paralela à tração na aresta vestibular externa da raiz, que parece ser motivada pela região apical do ligamento, ao se opor ao giro do dente que se apoia na cortical óssea vestibular.

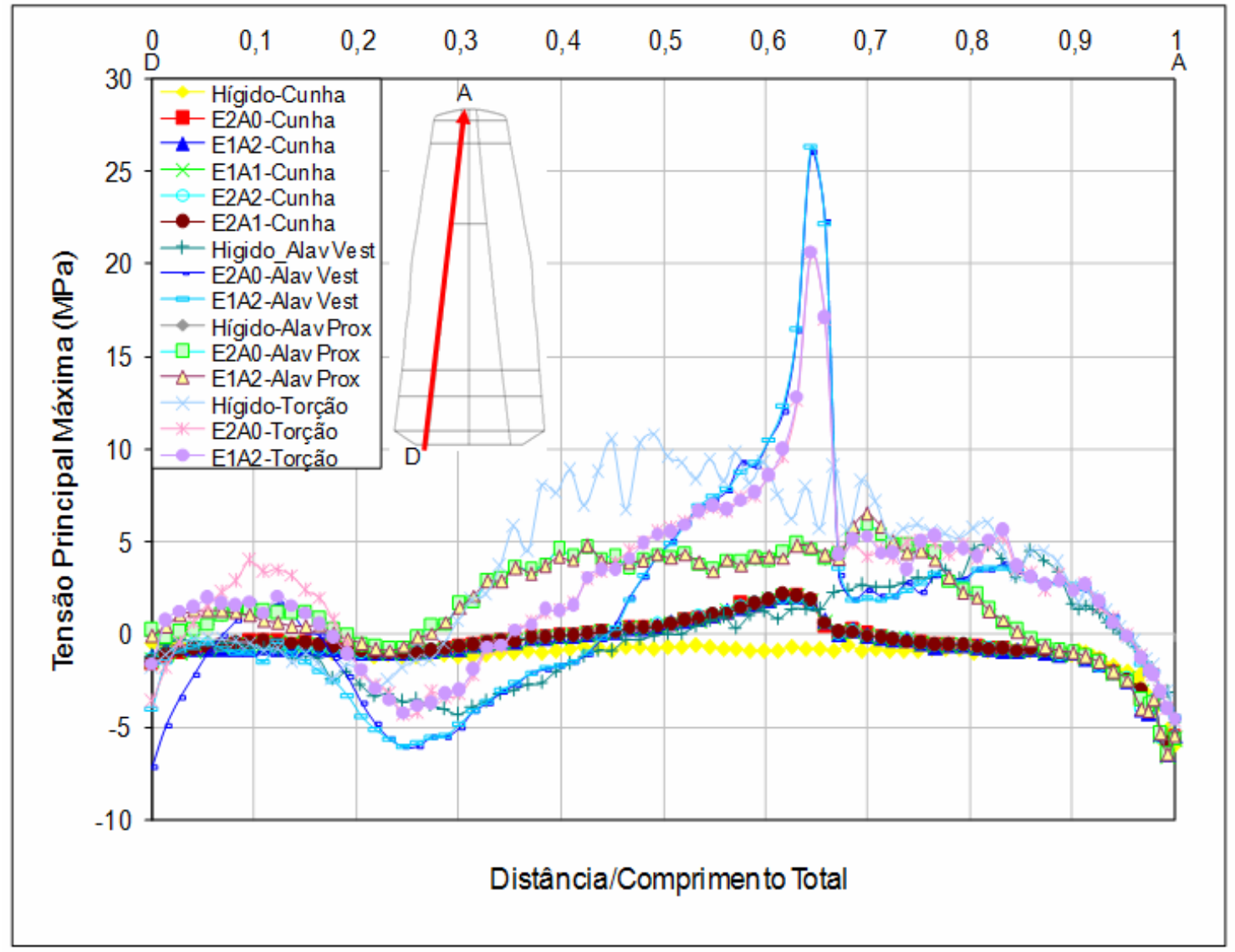

Figura 5.29 - Tensão principal máxima apresentada na aresta da dentina radicular, na face vestibular, em função da posição relativa do nó, a partir do ápice para a região cervical, sob todos os carregamentos 
Na Figura 5.30 é apresentada a aresta interna da face distal. Observam-se menores tensões nos modelos de cunha. Exceto os modelos de carregamento cunha, todos apresentam tração, o que mostra que praticamente toda a espessura da parede trabalha sob tração. Além do mais, nenhum dos modelos ultrapassou a tensão desenvolvida pelo modelo hígido carregado pra alavanca proximal, o que leva a fazer a hipótese de que em nenhum dos casos foi alcançado nível de tensão compatível com a fratura.

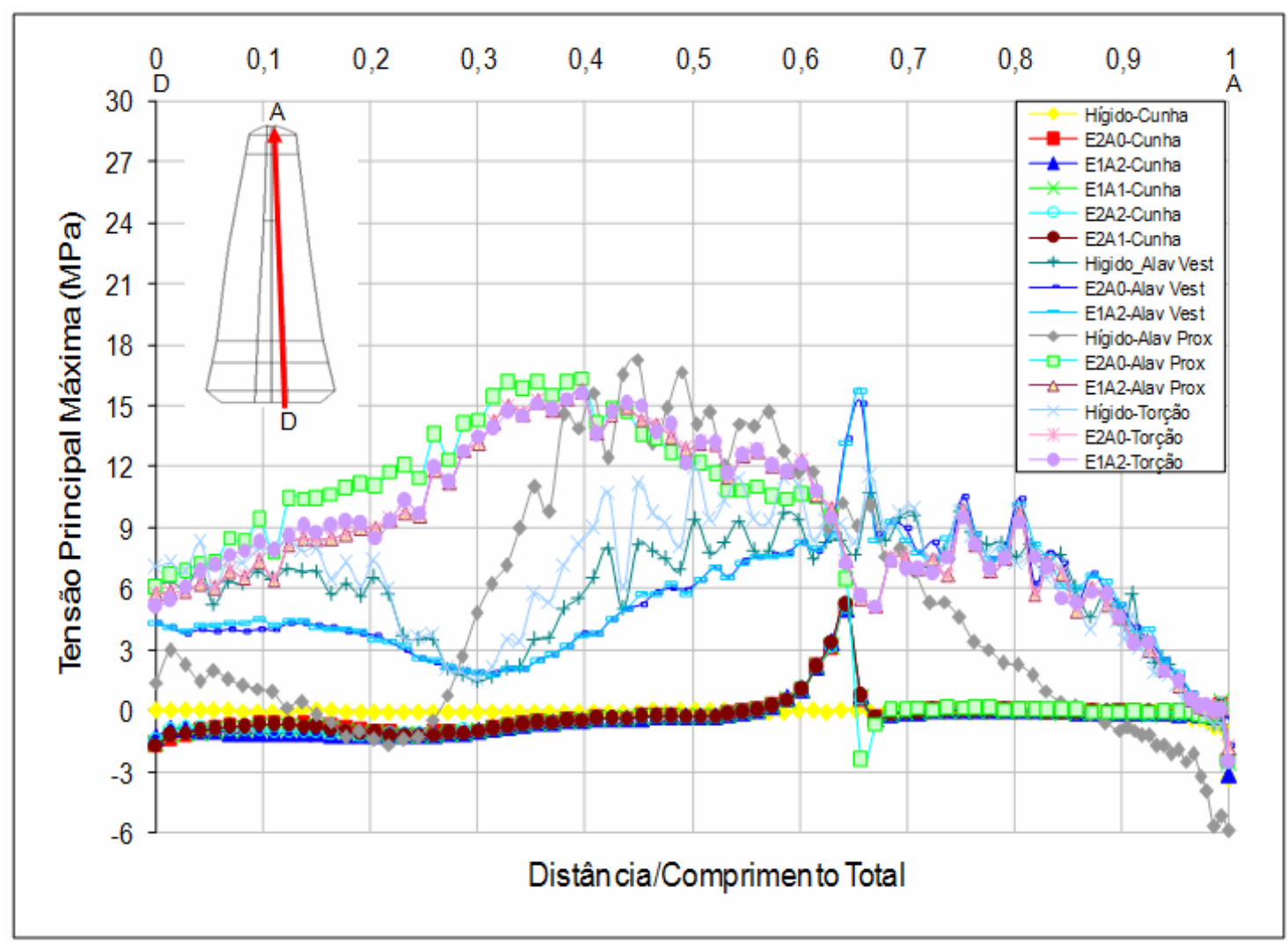

Figura 5.30 - Tensão principal máxima apresentada na aresta da dentina radicular, na face distal, em função da posição relativa do nó, a partir do ápice para a região cervical, sob todos os carregamentos

Na Figura 5.31 é apresentada a aresta interna da face mesial. Observam-se menores tensões nos modelos de cunha. As maiores trações ocorrem para o 
carregamento torque, independentemente da presença ou não da férula, que também não contribui para reduzir a tensão na alavanca vestibular.

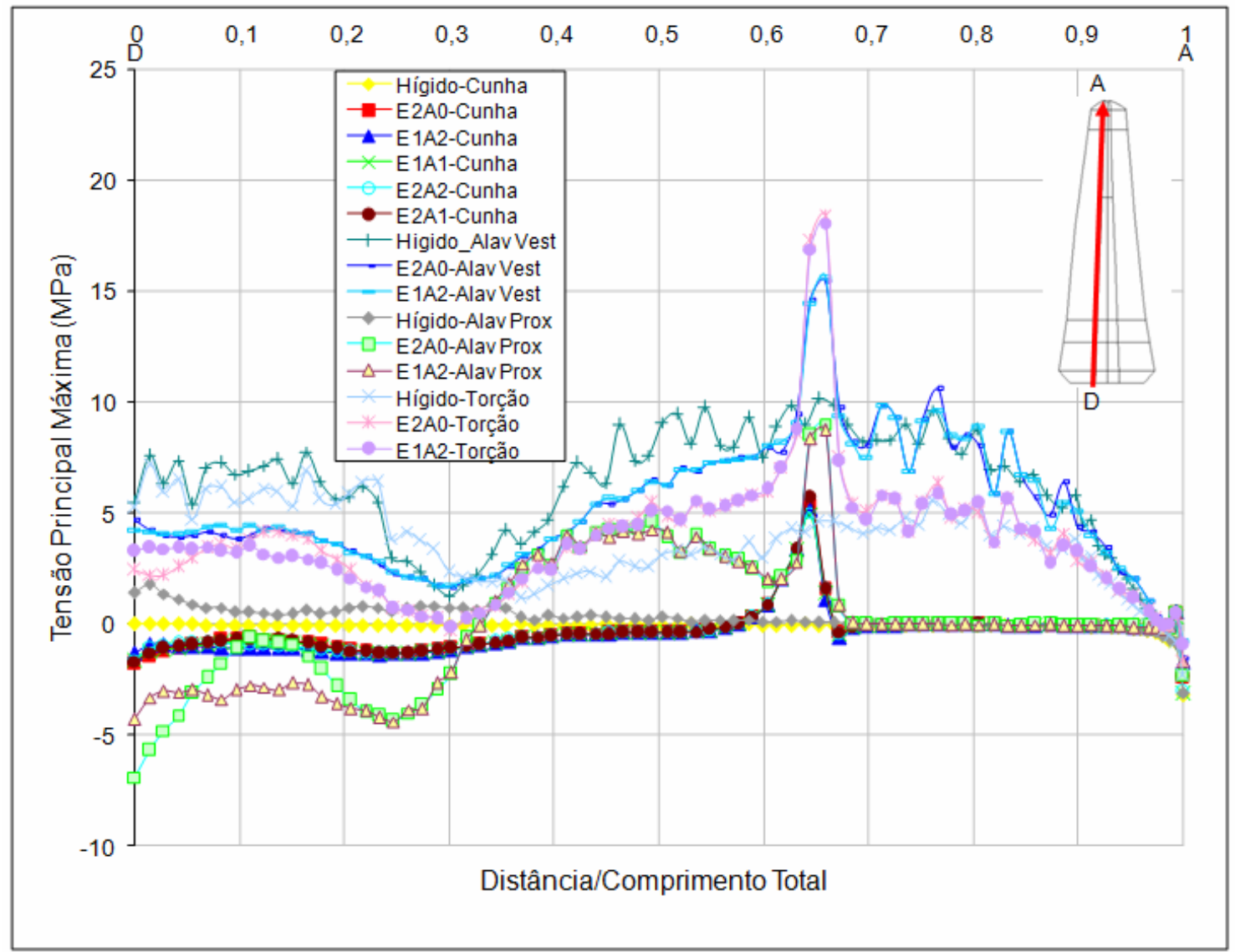

Figura 5.31 - Tensão principal máxima apresentada na aresta da dentina radicular, na face mesial, em função da posição relativa do nó, a partir do ápice para a região cervical, sob todos os carregamentos

Na Figura 5.32 é apresentada a aresta circular interna da dentina ao redor do ápice do pino. Observam-se menores tensões nos modelos de cunha, seguido dos modelos de alavanca proximal, torque e alavanca vestibular. A região mais tensionada continua sendo a vestibular. 


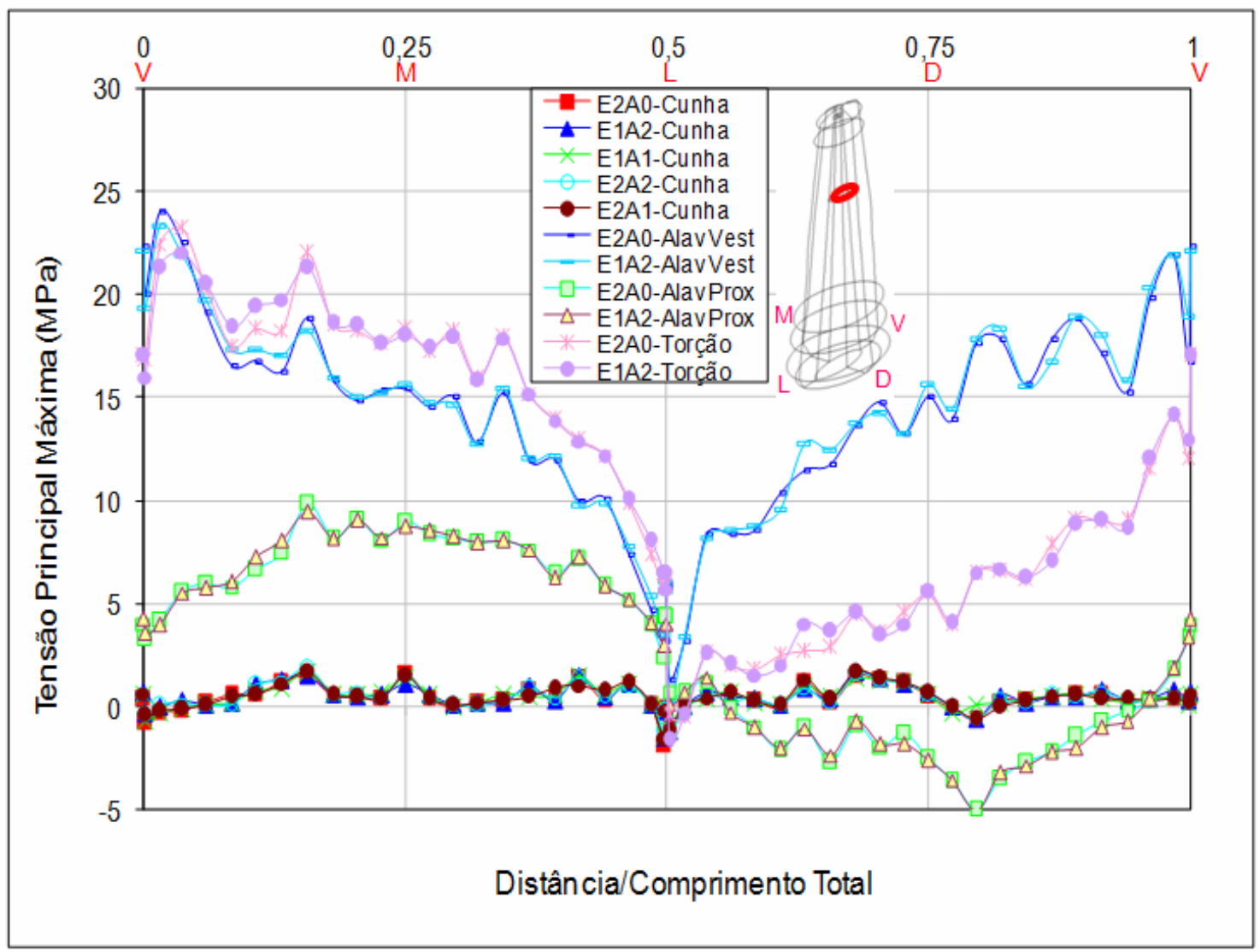

Figura 5.32 - Tensão principal máxima apresentada na aresta circular interna da dentina (V-M-L-D-V) ao redor do ápice do pino, em função da posição relativa do nó, sob todos os carregamentos

Cabe salientar que a modelagem utilizada neste estudo considerou todos os componentes sem equacionar eventuais problemas de contato, ou seja, sem falhas de união, o que não ocorre na realidade clinica.

Com relação à significação clínica dos resultados, parece que o melhor jeito de proteger o remanescente quando restaurado com pino seria garantir, pelo ajuste oclusal, que não ocorram carregamentos diferentes do longitudinal. A férula não parece ajudar na distribuição de tensões, mas, pelo contrário, parece prejudicar. A utilização de pinos perfeitamente aderidos não parece que possa conduzir à ocorrência de fraturas longitudinais baixas (abaixo da crista óssea), mas apenas a fraturas que provavelmente começariam na vestibular, na altura da crista óssea. $A$ 
parte mais vulnerável de todo o sistema restaurador é o cimento, que não resiste às tensões trativas a que é submetido nos carregamentos diferentes do longitudinal. 


\section{CONCLUSÕES}

Pode-se concluir que:

a) Em nenhum dos casos simulados (nos quais foi representada adesão perfeita entre todas as estruturas adjacentes) o efeito cunha foi evidenciado.

b) $\mathrm{O}$ carregamento longitudinal produz tensões que não justificariam a ruptura nem da dentina nem do cimento e são de módulo muito inferior às desenvolvidas por todos os outros tipos de carregamento.

c) A férula não é necessária para melhorar a distribuição de tensões, exceto para carregamento longitudinal, em que apresenta discreto efeito benéfico. Pelo contrário, a férula tende a aumentar as regiões submetidas às maiores trações.

d) No carregamento de alavanca vestibular foram encontradas, na face lingual, tensões de tração orientadas paralelamente ao eixo longitudinal e de magnitude suficiente para serem responsabilizadas por fraturas verticais acima da crista óssea. Estas tensões estão associadas ao dobramento do dente como um todo, apoiado na cortical óssea, que atua como um fulcro.

e) No cimento foram encontradas tensões que justificam sua fratura em todos os carregamentos, exceto para o caso de carregamento longitudinal. 


\section{REFERÊNCIAS ${ }^{2}$}

Asmussen E, Peutzfeldt A, Sahafi A. Finite element analysis of stresses in endodontically treated, dowel-restored teeth. J Prosthet Dent 2005;94:321-9.

Assif D, Bitenski A, Pilo R, Oren E. Effect of post design on resistance to fracture of endodontically treated teeth with complete crowns. J Prosthet Dent 1993;69:3640.

Assif D, Gofil C. Biomechanical considerations in restoring endodontically treated teeth. J Prosthet Dent 1994;71(8):565-67.

Anusavice JK. Phillips materiais dentários. $10^{\mathrm{a}}$ ed. Rio de Janeiro: Guanabara Koogan; 1998. 421 p.

Aykent F, Kalkan M, Yucel MT, Ozyesil AG. Effect of dentin bonding and ferrule preparation on the fracture strength of crowned teeth restored with dowels and amalgam cores. J Prosthet Dent 2006;95:297-301.

Baraban DJ. The restoration of pulpless teeth. Dent Clin North Am 1976; 11: 63353.

Baraban DJ. The restoration of endodontically treated teeth: an update. The $\mathrm{J}$ Prosthet Dent 1988;59(5):553-558.

Barkhordar RA, Radke R, Abbasi J. Effect of metal collars on resistance of endodontically treated teeth to root fracture. J Prosthet Dent 1989;62(6):676-78.

Berkovitz BKB, Holland CR, Moxham BJ. Anatomia, embriologia e histologia bucal. $3^{\circ}$ ed. Porto Alegre: Artmed Editora S.A.; 2004. 225 p.

Cailleteau J, Rieger M, Akin J. A comparison of intracanal stresses in a postrestored tooth utilizing the element method. J Endod 1992;18(11):540-4.

2 De acordo com Estilo Vancouver. Abreviatura de periódicos segundo base de dados MEDLINE. 
Cantisano W, Palhares WR, Santos HJ. Anatomia dental e escultura. $3^{\circ}$ ed. Rio de Janeiro: Guanabara Koogan; 1987. 200 p.

Caputo AA, Standlee JP. Pins and posts- why, when and how. Dental Clinics of North Am 1976;20(2):299-311.

Chan CP, Tseng SC, Lin CP, Huang CC, Tsai TP, Chen CC. Vertical root fracture in nonendodontically treated teeth-a clinical report of 64 cases in chinese patients. J Endod 1998;24(10):678-81.

Cohen BI, Musikant BL, Deutsch AS. Comparison of the retentive properties of two hollow-tube post systems to those of a solid post design. J Prosthet Dent 1993;70:234-8.

Cohen BI, Pagnillo M, Condos S, Deutsch AS. Comparison of torsional forces at failure for seven endodontic post systems. J Prosthet Dent 1995;74(4):350-7.

Colman HL. Restoration of endodonticaly treated teeth. Dent Clin North Am 1979; 23(4):647-62.

Contin I, Mori M, Campos TN. Restauração dos dentes endodonticamente tratados. In: Cardoso RJA, Gonçalves EAN (Org.) Odontologia arte ciência e técnica. São Paulo: Artes Médicas; 2002. cap. 17.

Cooney JP, Caputo AA,Trabert KC. Retention and stress distribution of taperedend endodontic posts. J Prosthet Dent 1986;55:540-6.

Davy DT, Dilley EL, Krejci RF. Determination of stress paterns in rootfilled teeth incorporating Various dowel desings. J Dent Res 1981;60(7):1301-10.

Deutsch A, Musikant BL, Cohen BI. Rational predictable posthole preparation. Compend Contin Educ Dent 1997;18(6):626-32.

Dulaimi SF, Wali Al-Hashimi MK. A comparison of spreader penetration depth and load required during lateral condensation in teeth prepared using various root canal preparation techniques. Int Endod J 2005;38:510-5. 
Farah J, Craig R. Finite element stress analysis of a restored axisymetric first molar. J Dent Res 1974;53(4):859-66.

Ferrari M, Mannocci F. Bonding of an esthetic fiber post into root canal with a 'one-bottle' system: a clinical case. Int J Endodont 2000;33:397-400.

Ferrario VF, Sforza C, Serrao G, Dellavia C, Tartaglia GM. Single tooth bite forces in healthy young adults. J Oral Rehabil 2004;31:18-22.

Friedman C, Sandrik J, Heuer M, Rapp G. Composition and mechanical properties of gutta-percha endodontic points. J Dent Res 1975;54(8):921-25.

Geen D, Brooklyn NY. Stereomicroscopic study of 700 root apices of maxillary and mandibular posterior teeth. Oral Surg Oral Med Oral Pathol 1960;13(6):72833.

Goerig AC, Mueninghoff LA. Management of endodontically treated tooth. Part I: Concept for restorative designs. J Prosthet Dent 1983;49(3):340-5.

Gutmann JL. Preparation of endodontically treated teeth to receive a post-core restoration. J Prosthet Dent 1977;38(4):413-8.

Guttman JL. The dentin-root complex: anatomic and biologic consideration in restoring endodontically treated teeth. J Prosthet Dent 1992;67(4):458-67.

Helfer AR, Melnick S, Schilder H. Determination of the moisture content of vital and pulpless teeth. Oral Surg 1972;34(4):661-9.

Hemmings KW, King PA, Setchell DJ. Resistance to torsional forces of various posts and core designs. J Prosthet Dent 1991;66(3):325-9.

Ho M, Lee S, Chen H, Lee M. Three dimensional finite element analysis of the effects of posts on stress distribuition in dentin. J Prosthet Dent 1994;72(4):36772.

Holmes DC, Diaz-Arnold AM, Leary JM. Influence of post dimension on stress disribuition in dentin. J Prosthet Dent 1996;75(2):140-7. 
Howe CA, Mckendry DJ. Effect of endodontic acces preparation on resistance to crown-root fracture. J Am Dent Assoc 1990;121:712-5.

Imura N, Zuolo ML. Endodontia para o clínico geral. São Paulo. Artes Médicas Ltda; 1998. 327 p.

Isidor F, Brondum K, Ravnholt G. The influence of post length and crown ferrule length on the resistence to cycling of bovine teeth with prefabricated titanium posts. Int J Prosth odont 1999;12(1):78-82.

Ko CC, Chu CS, Chung KH, Lee MC. Effetcs of post on dentin stress distribuition in pulpless teeth. J Prosthet Dent 1992;68(3):421-27.

Kumugai $\mathrm{H}$, Suzuki T, Hamada T, Sondang P, Fujitani M, Nikawa H. Occlusal force distribuition on the dental arch during various levels of clenching. J Oral Rehabil 1999;26:932-35.

Kurer HG, Combe EC, Grant AA. Factors influencing the retention of dowels. J Prosthet Dent 1977;38(5):515-525.

Lee SY, Huang HM, Lin CY. In vivo and in vitro natural frequency analysis of periodontal conditions, na innovative method. J Periodontol 2000;71:632-40.

Lertchirakarn V, Palamara JEA, Messer $\mathrm{HH}$. Load and strain during lateral condensation and vertical root fracture. J Endod 1999;25(2):99-104.

Lertchirakarn V, Palamara JE,Messer HH. Finite element analysis and straingauge studies of vertical root fracture. J Endod 2003;29:529-34.

Lewinstein I, Grajower R. Root dentin hardness of endodontically treated teeth. J Endod 1981;7(9):421-2.

Libman WJ, Nicholls JI. Load fatigue of teeth restored with cast posts and cores and complete crowns. Int J Prosthodont 1995;8:155-61.

Lloyd PM, Palik JF. The philosophies of dowel diameter preparation: a literature review. J Prosthet Dent 1993;69(1):155-61. 
Loney RW, Kotowicz WE, McDowel GC. Three-dimensional photoelastic stress analysis of the ferrule effect in cast post and cores. J Prosthet Dent 1990;63(5):506-12.

Martinez-Insua A, Da Silva L, Rilo B, Santana U. Comparison of the fracture resistances of pulpless teeth restored with a cast post and core or fiber post with a composite core. J Prosthet Dent 1999;80(5):527-32.

Morgano S. Restoration of pulpless teeth: application of traditional principles in present and future contexts. J Prosthet Dent 1996;75(4):375-80.

Morgano SM, Bracket SE. Foundation restoration in fixed prosthodontics: current knowledge and future needs. A literature review. J Prosthet Dent 1999;82(6):64357.

Onnink PA, Davis RD, Wayman BE. An in vitro comparison of incomplete root fractures associated with three obturation thecniques. J Endod 1994;20(1):131-5.

Papa J, Cain C., Messer HH. Moisture content of vital vs endodontically treated teeth. Endod Dent Traumatol 1994;10:91-3.

Pegoraro LF. Prótese fixa. São Paulo: Artes Médicas; 1999.

Pegoretti A, Fambri L, Zappini G, Bianchetti M. Finite element analysis of a glass fibre reinforced composite endodontic post. Biomaterials 2002;23(13):2667-82.

Peyton FA, Craig RG. Current evaluation of plastics in crown and bridge prosthesis. J Prosthet Dent 1963;13:743-53.

Pierrisnard L, Bohin F, Renault P, Barquins M. Corono-radicular reconstruction of pulpless teeth: a mechanical study using finite element analysis. J Prosthet Dent 2002;88:442-8.

Powers JM, Farah JW, Craig RG. Modulus of elasticity and strength properties of dental cements. J Am Dent Assoc, Otawa, 1976;92(3):não paginado.

Reeh ES, Messer HH, Douglas WH. Reduction in tooth stiffness as a result of endodontic and restorative preocedures. J Endod 1989;15(11):512-16. 
Rees JS, Jacobsen PH. Elastic modulus of the periodontal ligament. Biomaterials 1997; 18(14):995-9.

Reinhard RA, Krejci RF, Pao YC, Stannardt JG. Dentin stress in postreconstructed teeth with diminishing bone support. J Prosthet Dent 1983;62(9):1002-8.

Ruemping DR, Lund MR, Schnell RJ. Retention of dowels subjected to tensile and tensional forces. J Prosthet Dent 1979;41(2):159-166.

Rundquist BD, Versluis A. How does canal taper affect root stresses? Int Endod J 2006;39:226-37.

Sapone J, Lorencki SF. An endodontic-prosthodontic approach to internal tooth reinforcement. J Prosthet Dent 1981;45(2):164-74.

Standlee JP, Caputo AA, Hanson EC. Retention of endodontic dowels: effect of cement, dowel length, diameter, and design. J Prosthet Dent 1978;39:401-5.

Sedgley $\mathrm{CM}$, Messer $\mathrm{HH}$. Are endodontically treated teeth more britlle? J Endod 1992;18(7):332-5.

Shillingburg HT, Kaplan MJ, Grace CS. Tooth dimensions - A comparative study. J South Calif Dent Assoc 1972;40:830-9.

Shillingburg HT, Grace CS. Thickness of enamel and dentin. J South Calif Dent Assoc 1973;41:33-52.

Shilligburg Jr H, Hobo S, Whitsett LD, Jacobi R, Brackett SE. fundamentos de prótese fixa. $3^{\mathrm{a}}$ ed. Tradução Ivone Castilgo Benedetti. São Paulo: Quintessence; 1998. $472 \mathrm{p}$.

Sorensen JA, Martinoff JT. Intracoronal reinforcement and coronal coverage: a study of endodontically treated teeth. J Prosthet Dent 1984;51:780-4.

Sorensen JA, Engelman MJ. Ferrule design and fracture resistance of endodontically treated teeth. J Prosthet Dent 1990;63(5):529-36. 
Soriano HL. Método de elementos finitos em análise de estruturas. São Paulo: Edusp; 2003. 584 p.

Tamse A, Fuss Z, Lustig J, Kaplavi J. An evaluation of endodontically treated vertically fractures teeth. J Endod 1999a;7(25):506-8.

Tamse A, Fuss Z, Lustig J, Ganor Y, Kaffe I. Radiographic features of vertically fractured, endodontically treated maxillary premolars. Oral Surg Oral Med Oral Pathol Oral Radiol Endod 1999b;88(3):348-52.

Tamse A, Zilburg I, Halpern J. Vertical root fractures in adjacent maxillary premolars: an endodontic-prosthetic perplexity. Int Endod J 1998;31:127-32.

Testori T, Badino M, Castagnola M. Vertical root fractures in endodontically treated teeth: a clinical survey of 36 cases. J Endod 1993;19(2):87-90.

Tjan AHL, Miller GD. Comparison of retentive properties of dowel forms after application of torsional forces. J Prosthet Dent 1984;52(2):238-42.

Tjan AHL, Whang SB. Resistance to root fracture of dowel channels with various thicknesses of buccal dentin walls. J Prosthet Dent 1985;53(4):496-500.

Ueti H, Todescan R, Gil C. Estudo da espessura esmalte/dentina em função de idade, grupo de dentes e distância em relação à porção externa da coroa clínica. RPG 1997;4(2):153-9.

Vasconcellos AB, Mori M, Anduezza A, Silva EM. Tensões internas em prótese parcial fixa com dois sistemas de retenção corono-radicular: método dos elementos finitos. Rev Bras Odont 1999;59:206-10.

Weinstein AM, Klaawitter JJ, Cook SD. Implant-bone interface characteristics of bioglass dental implants. J Biomed Mater Res 1980;14(1):23-29.

Yamamoto M. Metal-ceramics: Principles and methods of Makoto Yamamoto. Chicago: Quintessence; 1985. 523 p. 
Zhi-Yue L, Yu-Xing Z. Effects of post-core design and ferrule on fracture resistance of endodontically treated maxillary central incisors. J Prosthet Dent 2003;89:368-73. 